Columbia Law School

Scholarship Archive

\title{
Governance of Steel and Kryptonite Politics in Contemporary Public Education Reform
}

James S. Liebman

Columbia Law School, jliebman@law.columbia.edu

Elizabeth R. Cruikshank

Christina C. Ma

author2517738@ssrn.com

Follow this and additional works at: https://scholarship.law.columbia.edu/faculty_scholarship

Part of the Education Law Commons

\section{Recommended Citation}

James S. Liebman, Elizabeth R. Cruikshank \& Christina C. Ma, Governance of Steel and Kryptonite Politics in Contemporary Public Education Reform, 69 FLA. L. ReV. 365 (2017).

Available at: https://scholarship.law.columbia.edu/faculty_scholarship/1950

This Article is brought to you for free and open access by the Faculty Publications at Scholarship Archive. It has been accepted for inclusion in Faculty Scholarship by an authorized administrator of Scholarship Archive. For more information, please contact scholarshiparchive@law.columbia.edu. 


\title{
GOVERNANCE OF STEEL AND KRYPTONITE POLITICS IN CONTEMPORARY PUBLIC EDUCATION REFORM
}

\author{
James S. Liebman ${ }^{*}$,Elizabeth Cruikshank ${ }^{* *}$, Christina Ma***
}

\begin{abstract}
Entrenched bureaucracies and special-interest politics hamper public education in the United States. In response, school districts and states have recently adopted or promoted reforms designed to release schools from bureaucratic control and empower them to meet strengthened outcome standards. Despite promising results, the reforms have been widely criticized, including by the educationally disadvantaged families they most appear to help.

To explain this paradox, this Article first considers the governance alternatives to bureaucracy that the education reforms adopt. It concludes that the reforms do not adopt the most commonly cited alternatives to bureaucracy - marketization, managerialism, or professionalism/craftand that none of those models effectively frees public education of special-interest politics.

This Article next argues that another governance and civic engagement model, democratic experimentalism, better explains the reforms and offers an attractive alternative to special-interest politics. This Article finds, however, that the reforms have not effectively implemented the "democratic" part of experimentalism, resulting in backlash from the families the reforms might benefit the most. This Article concludes by proposing a more fully democratic version of the reforms designed to improve student outcomes, powerfully engage key stakeholders, and diminish opposition.
\end{abstract}

INTRODUCTION

I. K-12 BUREAUCRACY AND ITS DISCONTENTS ..........................373

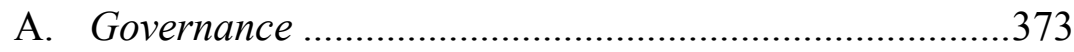

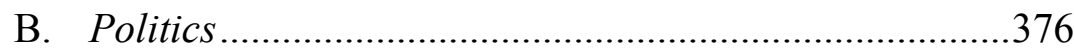

C. The Education Reform Response to

Bureaucracy and Special-Interest Politics.....................386

1. Education Reform in General................................387

2. Education Reform Examples....................................390

* Simon H. Rifkind Professor, Columbia Law School. The authors are grateful for the outstanding research assistance of Anoushka Asgari, Brian Campbell, Caleb Deats, Levi Downing, Peter Fountain, Mark Goldberg, Simon Greenberg, Remy Grosbard, Daniel Hamburg, Kelsey Hogan, Ryan Johansen, Tara Raam, Gautam Rao, Jason Schnier, Prateek Vasireddy, and Jamie Wolfe.

** Law Clerk, United States Court of Appeals for the Ninth Circuit.

*** Associate, Wachtell, Lipton, Rosen \& Katz. 
a. Moderate Steps: Houston, Boston, Charlotte-Mecklenberg, and Denver..................390

b. All-Out Reform: New York City, 2002-2013

c. Collaborative Reform: Baltimore.......................399

d. Federal Policy Under the Obama Administration

3. Two Puzzles

II. The INABILITY OF Prominent Alternatives TO BUREAUCRACY TO EXPLAIN OR SUSTAIN THE REFORMS 404

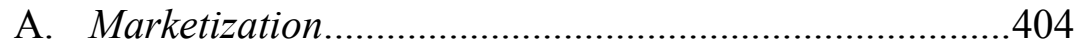

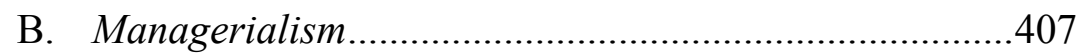

C. Professionalism/Craft.....................................................410

D. Defects Common to the Contending Alternatives.

III. DEMOCRATIC EXPERIMENTALISM AS AN ANTIDOTE TO BUREAUCRACY AND SPECIAL-INTEREST POLITICS 416

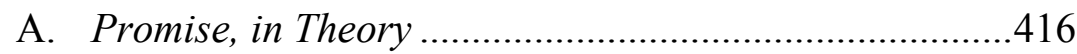

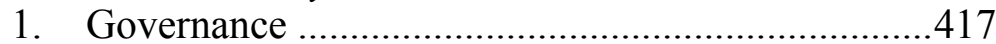

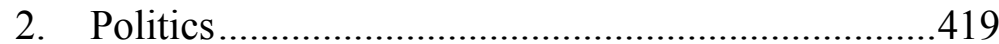

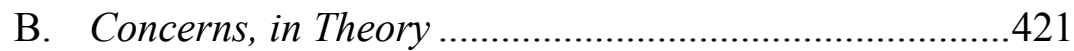

C. Promise, in Practice ......................................................423

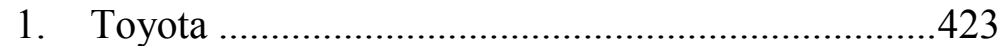

2. Drug Courts ...............................................................424

3. Environmental Protection........................................425

4. Chicago Community Policing ..................................427

5. Special Education in Finland .................................429

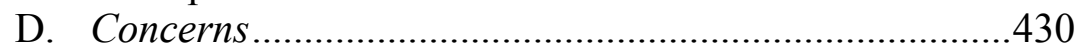

IV. DEMOCRATIC EXPERIMENTALISM IN-AND NOT IN-PUBLIC EDUCATION TODAY

A. Experimentalist Governance and the

Promise of the New Education Reforms.

B. The Absence of Experimentalist Politics and Risk of the Reforms' Demise

1. A New Vision of Education Politics ......................436

2. The Sobering Reality of Education Politics .............438

V. A MORE DEMOCRATIC EXPERIMENTALIST REGIME FOR PUBLIC EDUCATION 

A. The Challenge of Stakeholder Engagement in Public Education
B. Authentic Experimentalist Engagement
in Public Education....

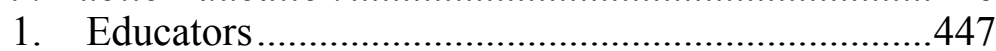

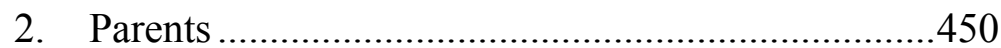
3. Supportive Organizations …………………............454

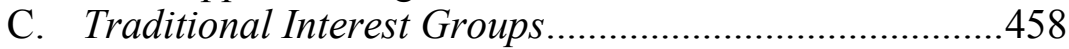

CONCLUSION.

\section{INTRODUCTION}

Since the turn of the century, a public education reform movement has taken shape in states such as Colorado, Delaware, Florida, Louisiana, Massachusetts, New Jersey, New Mexico, New York, and Tennessee, ${ }^{1}$ and in some of the nation's largest school districts, including Camden, Charlotte, Chicago, Cleveland, Denver, Hartford, Houston, Long Beach, Los Angeles, New Orleans, Newark, New Haven, New York City, Oakland, Sacramento, and Washington, D.C. ${ }^{2}$ Steps taken-emphasizing

1. See, e.g., Patrick McGuinn, Ctr. for Am. Progress, The State of Teacher EVALUATION REFORM 11-35 (2012), www.americanprogress.org/issues/education/report/2012/ 11/13/44494/the-state-of-teacher-evaluation-rform/ (evaluating and describing teacher evaluation reforms in Colorado, Delaware, New Jersey, Rhode Island, and Tennessee); THE BROAD PRIZE for Pub. Charter Sch., Uncommon Schools: Turning Urban Schools Into Springboards TO COLLEGE (2014), http://broadfoundation.org/wp-content/uploads/2016/03/1864-uncommon schoolswhitepaper.pdf (illustrating "successful college preparatory practices of ...38 public charter schools in New York, New Jersey, and Massachusetts" serving low-income students); U.S. Dep't of Educ., Race to the Top: Louisiana Report Year 2: December 2012-December 2013, at 13, 14, 17 (2014), https://www2.ed.gov/programs/racetothetop/performance/louisianayear-2.pdf (cataloguing Louisiana's Race to the Top initiatives, including "great teachers and leaders," "data systems to support instruction," and "turning around the lowest-achieving schools"); Press Release, U.S. Dep't of Educ., Delaware and Tennessee Win First Race to the Top Grants (Mar. 29, 2010), http://www.ed.gov/news/press-releases/delaware-and-tennessee-winfirst-race-top-grants (describing the reform strategy that earned Tennessee the first Race to the Top grant, including large-scale training of students, actionable data in the hands of educators, and a statewide educator evaluation system).

2. See, e.g., Paul T. Hill et al., Strife and Progress: Portfolio Strategies for MANAGING URBAN SCHOOLS 11-15 (2012) (detailing steps districts are using to improve schools, including enhanced school autonomy and accountability, pupil-based funding, and teacher development); Kristen L. Buras, New Orleans Education Reform: A Guide for Cities or a Warning for Communities? (Grassroots Lessons Learned, 2005-2012), 4 BERKELEY REV. EdUC. 123, 12830 (2013) (describing mass transition of traditional public schools to charter schools in New Orleans); CHARlotTe-MeCKLENBURG SCHS., THe ROAD TO REFORM (2010), www.cms.k12.nc.us/ mediaroom/Documents/The\%20Road\%20to\%20Reform.PDF (discussing Charlotte-Mecklenburg Schools' academic progress and systemic reform); Christine CAMPBELl \& BETHENY GROSS, CTR. on Reinventing Pub. Educ., Improving Student Opportunities and Outcomes in Hartford 
student mastery of rigorous "Common Core" standards, holding schools accountable for results on standardized tests and other metrics, closing or seriously restructuring failing schools, firing ineffective principals and teachers, opening charter and other innovative schools, and hiring educators less committed to traditional teachers' unions - have sharply divided Americans. ${ }^{3}$ A critically acclaimed and pro-reform 2010 documentary, Waiting for Superman, crystalized the debate. ${ }^{4}$

The film tracks several young students struggling to escape "the system" the documentary blames for decades of declining results in American public education. ${ }^{5}$ It begins with a declaration by Geoffrey Canada, founder of Harlem Children's Zone, that, rather than waiting for Superman to save us from "our system [that] is broken and ... feels

Public SCHOOLS 3 (2013), http://www.crpe.org/sites/default/files/Pub_EvidenceProject Hartford_jul13.pdf.pdf (analyzing Hartford's "portfolio management" strategy, including "closing and redesigning chronically low-performing schools, opening new schools, and using data to guide these decisions"); Frank G. JACKSON, City OF CleVEland, Cleveland's Plan fOR TRANSFORMING SCHOOLS 6-7 (2012), http://media.cleveland.com/metro/other/ClevelandPlan Final.pdf (describing Cleveland's "high-leverage system reforms," including replacing failing with high-performing schools and changing the central district's role from enforcing compliance with mechanical rules to overseeing continuous improvement); Emma Brown, D.C. to Close 15 Underenrolled Schools, WASH. POST (Jan. 17, 2013), http://www.washingtonpost.com/local/ education/chancellor-kaya-henderson-names-15-dc-schools-on-closure-list/2013/01/17/e04202f a-6023-11e2-9940-6fc488f3fecd_story.html (detailing a "fundamental remaking" of public education in Washington, D.C., with the city "at the leading edge of a national movement toward charters"); Editorial, School Reform in Newark, N.Y. TIMES (Nov. 15, 2012), http://www.nytimes.com/2012/11/16/opinion/school-reform-in-newark-with-a-new-teacherscontract.html?_r=0 (describing school reforms in Newark, New Jersey); Brenda Iasevoli, Why Did the Los Angeles Superintendent Resign?, AtLantic (Oct. 17, 2014), http://www.theatlantic.com/education/archive/2014/10/why-did-the-los-angeles-superintendentresign/381588/?single_page=true (cataloguing reforms by Los Angeles Unified School District and improved graduation rates and reading scores); Valerie Strauss, The Problem with Rahm's School Reforms in Chicago, WASH. POST (Sept. 11, 2012), http://www.washingtonpost.com/ blogs/answer-sheet/post/the-real-problem-with-rahms-school-reforms-in-chicago/2012/09/11/c7 7c3cc4-fba4-11e1-8adc-499661afe377_blog.html (describing school reforms promoted by Chicago Mayor Rahm Emanuel).

3. See, e.g., Bill Barrow, Common Core Spawns Widespread Political Fights, REAL ClEAR EDUC. (Mar. 24, 2014), http://www.realcleareducation.com/articles/2014/03/24/common_core_ spawns_widespread_political_fights_916.html (tracing the transformation of the bipartisan Common Core initiative to lift educational standards "into a political tempest fueling division" among both Republicans and Democrats); Amanda Ripley, Higher Calling, SLATE (June 17, 2014, 12:01 AM), http://www.slate.com/articles/life/education/2014/06/american_schools_need_ better_teachers_so_let_s_make_it_harder_to_become.html (describing “America's exhausting tug-of-war over schools" and distracting "brawls" over Common Core, testing, teacher tenure, evaluation and firings, and charter schools).

4. WAITING FOR SUPERMAn (Paramount Pictures 2010).

5. Mark Suster, Waiting for Superman: The Story of America's Broken Education System, BUS. INSIDER (Oct. 12, 2010, 6:13 PM), http://www.businessinsider.com/waiting-for-supermanthe-story-of-americas-broken-education-system-2010-10. 
impossible to fix," parents and the public must reclaim public education themselves. "We know what works," he says, and we ought to implement it: "quality teachers, more classroom time, world-class standards, high expectations, [and] real accountability."7 The film regards Canada and other reformers - such as Dave Levin and Mike Feinberg, founders of the KIPP Academy charter schools; Washington, D.C.'s then-schools chancellor Michelle Rhee; and teachers committed to moving even their most challenging students forward ${ }^{8}$ - as modern-day public education heroes who can deliver on what we know works. Supporting these claims is spotty but promising evidence of improved student outcomes. ${ }^{9}$

Viewers of the film can't escape the message that, like the film's compelling protagonists, poor and minority families nationwide stand to gain the most from the replacement of unaccountable and failing schools with more effective ones. On average, for example, black and Latino students are consistently between two and three years of learning behind white students ${ }^{10}$ and are only 20 to 30 percent as likely as their white peers to score at an advanced level. ${ }^{11}$ Reformers claim they can close these gaps - for example, by affording poor children four or five successive years of "good" as opposed to "average" teachers, which reasonable estimates suggest would generate learning gains as large as

6. WAITING FOR SUPERMAN, supra note 4 (introduction).

7. Id. (closing credits).

8. Id. ("Teachers are great, a national treasure. Teachers unions are generally speaking a menace and impediment to reform." (quoting a Newsweek reporter)).

9. Improved results by the Chicago Public Schools (CPS) under reform Superintendent Arne Duncan are an early example. From 2001 to 2008, the percentage of CPS students "meeting or exceeding standards" on the Illinois Standards Achievement Test increased from 18.7 to nearly 55. Press Release, Mayor's Press Office, Chicago Public Schools ISAT Scores Reach New High (Nov. 16, 2008), http://www.cityofchicago.org/city/en/depts/mayor/press_room/press_releases/ 2008/september_2008/chicago_public_schools.html; see William G. Ouchi, The SECRET OF TSL: The Revolutionary Discovery That Raises School Performance 237 (2009) (documenting CPS students' gains under Duncan and two reform superintendents who succeeded him); Nat'l Ctr. for Educ. Statistics, Reading 2013 Trial Urban District Snapshot REPORT (2013), https://nces.ed.gov/nationsreportcard/subject/publications/dst2013/pdf/2014467 xc4.pdf (showing that from 2003 to 2013, CPS students' average National Assessment of Educational Progress (NAEP) reading score increased from 193 to 206); NAT'L CTR. FOR EDUC. Statistics, Mathematics 2013 Trial Urban District SNapshot Report (2013), https://nces.ed.gov/nationsreportcard/subject/publications/dst2013/pdf/2014468xc4.pdf (documenting 2003-2013 increases in average CPR NAEP math score from 214 to 231). For other examples of improved student outcomes in reform districts and states, see infra notes 106, 109$10,113,141-50,172,179-82$ and accompanying text.

10. McKinsey \& Co., The ECONOMic Impact of the AChievement GaP IN America's SCHOOLS 9 (2009), http://mckinseyonsociety.com/downloads/reports/Education/achievement gap_report.pdf.

11. Id. at 11 . 
the difference in average achievement between students whose families do and do not qualify for public assistance. ${ }^{12}$

Yet, inadvertently, in illustrating Rhee's fortitude in the face of fervent opposition to reform, Waiting for Superman also documents a starkly different response from poor and minority families than the one the film predicts. The only portrayal of parents responding in an organized fashion to Rhee's reforms is a scene of outrage and chaos as a large group of black parents lambasts Rhee for closing their locally revered, albeit chronically failing, neighborhood schools. ${ }^{13}$

Nor has the film's broader message - that all Americans stand to gain from improved public schools - fared well. To be sure, defects in $\mathrm{K}-12$ education drag down the nation's standing in the world and its economy. ${ }^{14}$ For example, on the Organisation for Economic Cooperation and Development's (OECD) most recent Program for International Student Assessment (PISA), American fifteen-year-olds ranked twentyfirst in science and twenty-sixth in math, with average scores below the OECD's thirty-four-nation mean. ${ }^{15}$ Even schools in America's wealthiest communities are falling behind average schools in high-performing nations. ${ }^{16}$ On one analysis, the nation's failure to keep pace with betterperforming nations saps its gross domestic product of $\$ 1.3$ to $\$ 2.3$ trillion annually in 2008 dollars - a 9- to 16-percent drag on the economy, which is equivalent to a chronic major recession. ${ }^{17}$ Yet escalating middle-class

12. Eric A. Hanushek, Teacher Deselection, in Creating a New Teaching Profession 165, 172 (Dan Goldhaber \& Jane Hannaway eds., 2009).

13. For another example, a number of June 2014 reports indicated both that a year of widespread closures of schools in Chicago led to improved student performance among students moved out of failing schools and that black and Latino families bitterly opposed the closings. Compare Noreen S. Ahmed-Ullah, Year Later, Much Has Been Learned About School Closings, CHI. TRIB. (June 14, 2014), articles.chicagotribune.com/2014-06-14/news/ct-chicago-schoolyear-ends-met-20140615_1_welcoming-schools-barbara-byrd-bennett-closings (reporting on academic benefits to affected students from large-scale 2013-2014 school closings), with PAULINE Lipman et al., Collaborative for Equity \& Just. Educ., Root Shock: Parents' Perspectives ON School Closings in Chicago 9 (2014), http://ceje.uic.edu/wpcontent/uploads/2014/06/Root-Shock-Report-Compressed.pdf (reporting that surveyed parents believed school closures negatively affected their children).

14. NAT'L GOVERnORS ASS'N ET AL., BenChMARKIng FOR SuCCess: ENSURING U.S. Students Receive A World-Class EducAtion 16 (2008), http://www.achieve.org/files/BenchmarkingforSuccess.pdf ("America's global position is slipping not because U.S. schools are getting worse ... [but] because its educational outcomes have mostly stagnated while those in other countries have surged.").

15. Org. For Econ. Co-operation \& Dev., United States - Country Note - Results FROM PISA 2012, at 2 (2012), http://www.oecd.org/pisa/keyfindings/PISA-2012-results-US.pdf.

16. See Mercedes White, Can U.S. Schools Adopt Education Practices of Top-Performing Nations?, DeSERET News (May 24, 2012, 10:00 PM), http://www.deseretnews.com/article/ 765578482/Can-US-schools-adopt-education-practices-of-top-performing-nations.html.

17. MCKINSEY \& Co., supra note 10 , at 17. 
revolts against standardized testing, charter schools, and Common Core standards demonstrate that the reforms have not been widely accepted. ${ }^{18}$

A similar gap between expectations and reality undermined the Obama Administration's efforts to improve public education. Former Education Secretary Arne Duncan claimed that the disturbing conditions depicted in Waiting for Superman triggered a "quiet revolution" by parents, educators, elected officials, and charitable foundations seeking to transform sclerotic public education bureaucracies into hotbeds of innovation and institutional learning. ${ }^{19}$ In fact, however, the reforms sparked a noisy civil war between reformists and many other education stakeholders on both the right and the left. ${ }^{20}$

This state of affairs stems from a misalignment between two opposing features of the reforms. On one hand are steps to supplant the previously dominant bureaucratic governance of schools with promising institutional-learning structures. On the other hand is the reforms' almost total failure to replace special-interest politics that have long sustained old-style bureaucracy. As those who profit from traditional pluralism tenaciously fight to preserve the status quo, the reforms' most likely

18. See, e.g., Jessica Bakeman, Anti-Common Core Bandwagon Nears Capacity, Politico (Jan. 23, 2014, 5:00 AM), http://www.capitalnewyork.com/article/albany/2014/01/8539167/anticommon-core-bandwagon-nears-capacity (tracing the fight against Common Core to "grassroots level, with angry parents sounding off on social media and public forums about their children's struggles with the harder material"); Karla Scoon Reid, Testing Skeptics Aim to Build Support for Opt-Out Strategy, EDUC. WK. (Mar. 11, 2014), http://www.edweek.org/ew/articles/2014/03/ 12/24boycotts_ep.h33.html (describing "wave of anti-testing sentiment among parents," leading more of them to "refuse to let their children take state-mandated tests"); Patrick Wall, Troubled by the State Reading Test, Manhattan Principals Decide to Protest, Chalkbeat (Apr. 10, 2014), http://ny.chalkbeat.org/2014/04/10/troubled-by-the-state-reading-test-manhattanprincipals-decide-to-protest/ (describing protests against Common Core exams at dozens of schools in "well-heeled neighborhoods" in New York City).

19. See Arne Duncan, The Quiet Revolution: Secretary Arne Duncan's Remarks at the National Press Club, U.S. DeP'T Educ. (July 27, 2010), https://www.ed.gov/news/speeches/ quiet-revolution-secretary-arne-duncans-remarks-national-press-club (associating Waiting for Superman with a "revolution" in public education benefiting and quietly supported by families previously denied access to good schools).

20. See, e.g., Gabriel Arana, Common Core's Political Fiasco: How It United the Left and Right Against It, SALON (Sept. 29, 2014, 6:59 AM), http://www.salon.com/2014/09/29/ common_cores_political_fiasco_how_a _program_united_the_left_and_right_against_it; Walter Russell Mead, Blue Civil War: The Battle for California, AM. INT. (Mar. 6, , 2013, 7:11 PM), http://www.the-american-interest.com/2013/03/06/blue-civil-war-the-battle-for-california (seeing debate between school reformers and teachers' unions as sparking a battle between wings of the Democratic party for control of California politics); Judith Warner, Is Michelle Rhee's Revolution Over?, N.Y. TIMES (Oct. 1, 2010), http://www.nytimes.com/2010/10/03/magazine/ 03 fob-wwln-t.html (cataloguing electoral defeats of "candidates closely associated with [education] reform[s]" because of "enmity from teachers, their unions and, surprisingly enough to outside observers, many public-school parents"). 
beneficiaries - parents and students - have no evident alternative to interest-group politics for understanding or directly participating in apparently distant "corporate" and "technocratic" reforms. ${ }^{21}$ In reformers' haste, they have disenfranchised those they sought to empower and help. This gap has enabled stalwarts of the old system to convince the reforms' intended beneficiaries that the reforms undermine democratic control of public education and public education itself. Even as reformers have stopped waiting for Superman and are busy replacing desiccated bureaucracies with governance models of steel, the persistence of special-interest politics has been their kryptonite, neutralizing the reforms' extraordinary potential.

This Article argues that the success of the school governance reforms being implemented nationwide depends on equally comprehensive shifts in civic engagement that have not been widely pursued. The solution it proposes-immersing families and other external stakeholders in the until-now entirely internal reforms - would transform how the public interacts with school systems and shapes education policy and provide a model of civic engagement and public accountability with the potential to moderate the nation's broader political gridlock.

Part I of this Article reprises widely accepted accounts of the conditions under which bureaucracies fail to make and implement effective policy and of the tight link between bureaucracy and specialinterest politics. Part I then explains why the combination of the two has been disastrous for $\mathrm{K}-12$ education policy and how the education-reform movement has tried to reverse those ill effects.

Part II shows that the education reforms are often misunderstood as instances of three alternatives to bureaucracy: marketization, managerialism, and professionalism/craft. Exploring these governance models also exposes a flaw all three share: They offer no effective substitute for special-interest politics.

Part III argues that a fourth model, "democratic experimentalism," offers a more promising alternative, which in theory effectively transforms - by integrating - governance and politics through a process of participatory problem-solving.

21. See, e.g., Geoff Decker, Fariña's Parent Engagement Strategy Starts with Index Cards, CHALKBEAT (Jan. 9, 2014), http://ny.chalkbeat.org/2014/01/09/farinas-parent-engagementstrategy-starts-with-index-cards ("The way the [D]epartment [of Education] engages with parents was an easy target for every Democratic candidate [to replace Mayor Bloomberg]."); Yoav Gonen, De Blasio Swipes at Bloomberg over Education, N.Y. Post (Jan. 30, 2014, 5:40 AM), http://nypost.com/2014/01/30/de-blasio-swipes-at-bloomberg-over-education (quoting Mayor Bill de Blasio as saying, "I am not trying to bring an outside model, a corporate model, a privatesector model to [the] public-sector"); Eliza Shapiro, Carmen Fariña to Head D.O.E., PoLiTiCo (Dec. 30, 2013, 11:45 PM), http://www.capitalnewyork.com/article/city-hall/2013/12/8537832/ carmen-farintildea-head-doe (quoting a critic of education who predicts a conversion "from a technocratic staff to a deeper educational staff"). 
Part IV shows how experimentalism better describes the recent education-reform movement's policies, such as the Common Core standards, portfolios of instructional options including charter schools, measurement based on standardized and other assessments of student success and teacher quality, and collaborative problem-solving. Part IV then links the backlash the reforms have triggered to their failure to implement the "democratic" part of democratic experimentalism by integrating affected families and other external constituencies into the internal problem-solving that typifies the experimentalist reforms.

Finally, Part V sketches out a version of education reform under which experimentalist governance becomes truly democratic, neutralizing the kryptonite politics that thus far have weakened the reforms.

\section{I. $\mathrm{K}-12$ BUREAUCRACY AND ITS DiSCONTENTS}

Although bureaucracy and allied interest-group politics dominated organizational design and accountability during much of the twentieth century, the conditions for their success deteriorated substantially in the last third of that century. Those changes were particularly disruptive to urban public school bureaucracies. Not surprisingly, therefore, the beginning of the twenty-first century has seen a significant move away from the structures that previously dominated large public school systems, but, as this Part concludes, those changes have been puzzlingly incomplete.

\section{A. Governance}

For decades, critics of ineffective and increasingly sectarian government have blamed governance by bureaucracy, which is now the feature the public most associates with and loathes about government and its agencies. ${ }^{22}$ This association puts the very capacity of the modern state to solve public problems at stake in the debate over whether there are workable alternatives to bureaucracy.

This has not always been so. ${ }^{23}$ Bureaucracy developed as an antidote to earlier organizational structures, which were undermined by caste,

22. See Christopher K. Ansell, Pragmatist Democracy: Evolutionary Learning as Public Philosophy 3, 65 (2011); John E. Chubb \& Terry M. Moe, Politics, Markets, And AMERICA's SchOOLS 3-4 (1990); Mary Anne Raywid, Rethinking School Governance, in Restructuring Schools: The NeXt Generation of EduCATIONAL Reform 152, 153 (Richard F. Elmore ed., 1990) [hereinafter ELMORE] ("The second half of the twentieth century . . . has been a period of increasing public skepticism about major societal institutions and of growing lack of confidence in large organizations.").

23. For a collection of essays generally defending bureaucracy, see THE VALUES OF BurEaUCRACY (Paul du Gay ed., 2005). 
patronage, parochialism, and corruption. ${ }^{24}$ In its public- and privatesector forms, bureaucracy played a decisive role in every major twentieth-century milestone, including the triumph of democracy over authoritarianism across two hot and one cold world wars; the globalization of communication, transportation, and public health; and the progressive social movements that ended racial apartheid in the United States and, in turn, extended equal rights to women, the elderly, the disabled, and other marginalized groups. ${ }^{25}$

To accomplish these ends, bureaucracies rely on experts at the top to design products or services tied to the organizations' missions and a set of prescriptive rules or instructions specifying how employees lower in the hierarchy are to build and market products and provide services. ${ }^{26}$ Typically, the rules govern not only the materials provided to street-level employees and the operational steps employees take but also the processes, rewards, and consequences that supervisors use to ensure that their subordinates comply with the experts' instructions. ${ }^{27}$

Centralization of power and hierarchically enforced rules serve two main functions. First, they delegate important decisions to individuals whose expertise enables them to design products and services that align to the organization's mission and give clear instructions to nonexperts for operationalizing those designs. ${ }^{28}$ Second, they render the organization accountable, with responsibility and blame running transparently up the bureaucratic hierarchy. ${ }^{29}$

24. See, e.g., Ken Morrison, Marx, Durkheim, Weber: Formations of Modern Social Thought 298-300 (1995); Antonino Palumbo \& Alan Scott, Bureaucracy, Open Access, and Social Pluralism: Returning the Common to the Goose, in THE VALUes of BUREAUCRACY, supra note 23 , at $281,281-83$.

25. See, e.g., Christina Wolbrecht, The Politics of Women's Rights: Parties, Positions, And Change 156-57 (2000); Augustus Jones Jr. \& Peter Bishop, Policy Making by the Lower Federal Courts and the Bureaucracy: The Genesis of a National AIDS Policy, 27 Soc. SCI. J. 273, 274 (1990); Burton Levy, The Bureaucracy of Race: Enforcement of Civil Rights Laws and Its Impact on People, Process, and Organization, 2 J. BLACK STUD. 77, 85-88 (1971); Charles F. Sabel \& William H. Simon, Destabilization Rights: How Public Law Litigation Succeeds, 117 HARV. L. REV. 1015, 1016, 1018-19 (2004) (linking bureaucracy and public-law litigation on behalf of disadvantaged populations).

26. See, e.g., ANSELl, supra note 22, at 76 ("'Bureaucracy is not a dynamic institution committed to solving problems and attaining objectives. Rather it is a relatively passive and conservative system preoccupied with detailed implementation of received policies."' (quoting Philippe Nonet \& Philip Selznick, LaW and Society in TRansition: Toward ResPonsive LaW $65(2001)))$.

27. See, e.g., The VAlues of Bureaucracy, supra note 23, at 2-6.

28. See, e.g., Rudi Volti, An Introduction to the Sociology of Work AND OCCUPATIONS 83-84 (2d ed. 2012).

29. Id. at 83 . 
The problem, however, is that bureaucracy requires reasonably stable and predictable conditions to operate effectively. Only then can experts develop mission-based policies and rules that can be applied relatively uniformly across multiple sites and monitor implementation and take remedial action as necessary without becoming obsolete in the time it takes to develop or implement the policies. Today, these conditions often are not present. Instead, the number, diversity, and complexity of challenges faced each day across cities, counties, states, and the nation generate "wickedly" multidimensional problems, making it difficult for central experts to "keep up."

Compounding the problem of diversity is the very success of bureaucratically administered private companies and public agencies and courts. The former have led consumers to expect their every, increasingly varied need and want to be instantly met. The latter have expanded the number of individuals with the right to insist that their often particularly challenging needs and wants be treated the same as others. These trends increase the complexity of designing, delivering, and regulating access to desired products and services and heighten the need for flexibility.

Public education provides a salient example. New demands on education fall with special force on school systems charged with readying ever more diverse and challenging populations for a vast array of globally competitive careers, ${ }^{31}$ while navigating a burgeoning set of controversies about which parents feel empowered to insist that their idiosyncratic values be honored. ${ }^{32}$ Even the most basic goals of education are contested, and "there is no consensus about what priority should be given

30. See, e.g., ANSELL, supra note 22, at 4, 84-103; Hilda Borko et al., Wicked Problems and Other Thoughts on Issues of Technology and Teacher Learning, 60 J. TCHR. EDUC. 3, 3 (2009) (defining "wicked" problems in education, which have "complex variables - all of which are dynamic, contextually bound, and interdependent”); Horst W.J. Rittel \& Melvin M. Webber, Dilemmas in a General Theory of Planning, 4 PoL'y SCIENCES 155, 161 (1973); Charles Sabel et al., Individualized Service Provision in the New Welfare State: Lessons from Special Education in Finland, 62 SitRA STUD. 10, 17-18, 35-37, 60 (2011).

31. See, e.g., Frank Levy \& Richard J. Murnane, The New Division of Labor: How Computers Are Creating the NeXt Job MARKet 149-56 (2004) (discussing shifts in labor demand in response to advances in technology); Frank Levy \& Richard J. Murnane, Why the Changing American Economy Calls for Twenty-First Century Learning: Answers to Educators' Questions, 110 New Directions FOR Youth DEV. 53, 54-55 (2006).

32. See, e.g., Steven Farkas \& Ann Duffett, FDR GrP., Maze of Mistrust: How District Politics and Cross Talk Are Stalling Efforts to Improve Public Education 16 18 (2014), https:/www.kettering.org/catalog/product/maze-mistrust-how-district-politics-andcross-talk-are-stalling-efforts-improve (noting the increasing tendency of officials to give schools and school systems responsibility for resolving controversies and providing services that previously were the province of families and communities, including exposure to the arts, diet, "play," religious holidays, and sex education). 
to the various aims." ${ }^{33}$ Measurement limitations make it difficult to ascertain "whether one method of providing school services is consistently better in terms of output effects . . . than any other method." 34 The answers to these questions vary across states, districts, schools, and individual families and children.

Given these uncertainties, it is no longer possible for public schools to meet the needs of their diverse populations of children ${ }^{35}$ and the demands of our complex economy and polity simply by asking teachers to follow instructions codified in textbooks that state or local school boards select every few years in service of a centrally mandated curriculum. ${ }^{36}$ Instead, the bureaucracies that decades of accreted central mandates and standard operating practices, civil service regulations, and collective bargaining agreements have left firmly in charge of schools more often than not prevent modern educators from developing effective strategies and improving results for their students. ${ }^{37}$

\section{B. Politics}

Modern conditions not only weaken bureaucratic expertise but also blur the lines of authority that bureaucratic accountability requires. In one version, bureaucratic accountability begins when the public elects representatives, who set policy and appoint central administrators to implement it. The administrators translate policy into tangible rules to govern the action of street-level employees and guide supervisors who assure street-level compliance. ${ }^{38}$ When the system fails, vigilant clients or regulated entities complain to their elected representatives, or replace those representatives with more attentive ones, who reassert the public

33. John Pincus, Incentives for Innovation in the Public Schools, in SocIal Program IMPLEMENTATION 43, 45 (Walter Williams \& Richard F. Elmore eds., 1976).

34. Id.

35. Archon Fung, Empowered Participation: ReinVenting Urban Democracy 19 (2004) (noting local conditions can make "expert prescriptions seem irrelevant or ineffective" across diverse communities).

36. See Susan Moore Johnson, Redesigning Teachers' Work, in Elmore, supra note 22, at 125, 127 ("Schools [ought to be] human-service organizations where techniques are varied and responsive to individual requirements, rather than factories where procedures are rationalized and predictable.").

37. See, e.g., ChubB \& MoE, supra note 22, at 38-41; see also Raywid, supra note 22, at 170 ("[I]n most contemporary schools, bureaucracy is [still] believed to be the only plausible, viable form of social organization...[complete with] differential status and authority assignments, fixed roles, clearly divided responsibilities, clearly demarcated measures of accountability and written rules.").

38. See, e.g., ANSELL, supra note 22, at 69-71. 
will through the hierarchy. ${ }^{39}$

In practice, bureaucracy has been a victim of its own success. ${ }^{40}$ The more effectively organizations mass-produced and seamlessly delivered goods and services to individuals who previously had to obtain them through their own efforts, the more those organizations freed individuals to attend to their productive and leisure time and diminished their incentive to police their individually minuscule stake in how large institutions behaved. ${ }^{41}$

In place of individual accountability arose special-interest, or "pluralist," politics. These politics rely on intermediary organizations and class-action lawsuits to aggregate the modest interests and mildly implicated values that many people hold in common in relation to largescale activity, exerting substantial influence while demanding only modest contributions of members' time and resources. ${ }^{42} \mathrm{~A}$ classic example is public-sector unions representing teachers, sanitation workers, police officers, fire fighters, and even social workers and legalaid lawyers. ${ }^{43}$ Although relations between these unions and bureaucracies often were adversarial at first, negotiation and cooperation replaced conflict as a way for the sides to buy peace and to bolster bureaucratic accountability. The agreements reached became some of the most important rules by which bureaucracies managed themselves and their relationships with stakeholders.

39. Id. at 136-37 ("In the traditional logic of democracy, the public makes demands, but shifts responsibility to elected officials; elected officials, in turn, make demands, but shift responsibility to the opposition and to the bureaucracy.").

40. See, e.g., James Q. Wilson, The Bureaucracy Problem, 6 PuB. InT. 3, 5 (1967) ("[T]he more a bureaucracy is responsive to its clients - whether those clients are organized by radicals ... or represented by Congressmen anxious to please constituents-the less it can be accountable to presidential directives.").

41. See Robert A. Dahl, Who Governs? Democracy and Power in an American City 223-24 (2d ed. 2005) (explaining the average person can more efficiently pursue primary goals by "working at his job, earning more money, taking out insurance, joining a club, planning a vacation, [or] moving to another neighborhood or city" than he can by undertaking political activity); Bruce A. Ackerman, The Storrs Lectures: Discovering the Constitution, 93 YALE L.J. 1013, 1022-34 (1984) (contending that except in rare "constitutional moments," the public avoids public engagement, allowing factions to manipulate political life in pursuit of narrow interests).

42. $C f$. Jefrerey R. Henig, The End of Exceptionalism in American Education: The Changing Politics of School Reform 26 (2013) (identifying many day-to-day decisions by schools and districts that "are political in their consequences: some groups win and others lose").

43. As of 2013, the unionization rate of public-sector workers was more than five times higher than that of private-sector workers and three times higher than the nation's overall unionization rate (respectively, 35.3, 6.7, and 11.3 percent). BUREAU OF LABOR STATISTICS, U.S. DEP'T OF LABOR, UNION MEMBERS-2013, at 1 (2014), https://www.bls.gov/news.release/ archives/union2_01242014.pdf. 
In an important minority of cases, large-scale actors were slow to adopt bureaucratic governance, ignored the demands of individuals who were harmed, and were impervious to strife and negotiation. Prisons run like plantations and largely governed by inmate "trusties" were an example, ${ }^{44}$ as were organizations responsible for badly treating minorities and women, ${ }^{45}$ rogue police forces, ${ }^{46}$ raggedly financed public school systems,${ }^{47}$ and chaotic child-welfare agencies. ${ }^{48}$ In these situations, "public interest" groups used class-action litigation to aggregate clients" interests and convince courts to decree the adoption of - or to orchestrate negotiations in which managers accepted - bureaucratic rules as a way to "professionalize" their operations. ${ }^{49}$

As these examples illustrate, the aggregation of otherwise fragmented interests can effectively keep bureaucracies accountable for their adverse impact on employees, customers, clients, and others. Aggregation of interests is especially effective when the interests asserted have fundamental constitutional status that the bureaucratic institution has egregiously ignored or when such interests do not substantially compete with each other and with those the bureaucracy is intended to serve. Even when different stakeholders' interests do compete, interest-aggregation can work tolerably well if each group's representation is roughly proportionate to its numbers.

Problems arise, however, when these conditions do not obtain. Special-interest organizations may themselves threaten constitutionally

44. See, e.g., Hutto v. Finney, 437 U.S. 678, 682 n.6 (1978) (invalidating "trusty" system of inmate supervision of other inmates in Arkansas prisons).

45. See, e.g., Phillips v. Martin Marietta Corp., 400 U.S. 542, 544 (1971) (requiring employer to come up with "bona fide occupational" reason for different hiring policies for similarly situated men and women); Griggs v. Duke Power Co., 401 U.S. 424, 427, 429 (1971) (invalidating pay and promotion provisions subjecting mainly African-American employees to low-paying dead-end jobs).

46. Cf. Rizzo v. Goode, 423 U.S. 362, 379-81 (1976) (reversing lower court ruling in favor of class action plaintiffs alleging severe misconduct by police officers on grounds that plaintiffs lacked standing and the decree issued unduly burdened officers' discretion to perform their duties).

47. See, e.g., Serrano v. Priest, 487 P.2d 1241, 1266 (Cal. 1971) (invalidating California's unequal system of school funding based on local property taxes).

48. See Judith Meltzer et al., Introduction and Overview, in For THE Welfare of Children: Lessons Learned from Class Action Litigation vi-vii (Ctr. for the Study of Soc. Policy ed., 2012), http://www.cssp.org/publications/child-welfare/class-action-reform/For-theWelfare-of-Children_Lessons-Learned-from-Class-Action-Litigation_January-2012.pdf (citing successful and unsuccessful litigation efforts to reform child-welfare agencies).

49. See Abram Chayes, The Role of the Judge in Public Law Litigation, 89 HARv. L. Rev. 1281, 1298, 1299 (1976) (discussing remedial "negotiation" prompted by judges in public-law litigation cases); Sabel \& Simon, supra note 25, at 1065-66 (discussing decrees that emerged from "defendants ... sympathetic to the plaintiffs" claims" or to "the new resources that the decree induces"). 
recognized values or interests with no or weak representation of their own. Strong, stable special-interest organizations are likely to arise only around a relatively large set of individuals with a small and easily defined set of common interests and a willingness and capacity to invest in the group's pursuit of those interests. ${ }^{50}$ When the full range of stakeholders affected by a public agency or private organization do not share the same interests, the subset of preferences special-interest groups do represent will disproportionately influence bureaucratic policies at the expense of preferences that are not as well-represented. ${ }^{51}$ Distortions also arise when the represented subset of interests is misaligned with the interests of the constituencies the bureaucracy is supposed to serve-as when trade associations representing regulated industries "capture" public agencies at the expense of the unorganized consumers or dispersed members of the public whom the agency is supposed to protect. ${ }^{52}$

Aggravating matters is the problem of the "street-level bureaucrat." 53 As social scientists Michael Lipsky and James Q. Wilson and others have demonstrated, hierarchical, rule-driven bureaucracies that rely on a large workforce of field-level employees to carry out their mission in daily interaction with a varied and far-flung clientele-police forces, public school systems, veterans' hospitals, social welfare administrations, State Department consular services, and many others-face an accountability dilemma. ${ }^{54}$ Their claim of public accountability rests squarely on the ability of central experts to transform general directives from elected officials representing voters into operable plans and rules. ${ }^{55}$ But given the inability of centralized plans and implementing rules to anticipate and specify appropriate responses in many situations street-level employees encounter, the agency cannot accomplish its mission unless its street-

50. Mancur Olson, The Logic of Collective Action: Public Goods and the Theory OF GROUPS 36 (1965) ("[Small groups] may very well be able to provide themselves with a collective good simply because of the attraction of the collective good to the individual members.").

51. Id.

52. See George J. Stigler, The Theory of Economic Regulation, 2, 12-13 BeLl J. ECON. \& MGMT. SCI. 3 (1971) (providing examples of regulatory "capture" by financial, natural resources, and transportation industries).

53. See Michael Lipsky, Street-Level Bureaucracy: Dilemmas of the Individual in Public SERVICES xi (1980).

54. Id. at 15 (identifying "certain characteristics of the jobs of street level bureaucrats [that] make it difficult, if not impossible" to eliminate street-level discretion). Discussing the problem of the street-level bureaucrat in specific fields are: JAMES Q. WILSON, VARIETIES OF POLICE BeHAVIOR: THE MANAGEMENT OF LAW AND ORDER IN EIGHT COMMUNITIES 84 (1978); THEODORE R. Sizer, Horace's Compromise: The Dilemma of the American High School 207, 210 (1992); William H. Simon, The Invention and Reinvention of Welfare Rights, 44 MD. L. REv. 1, 36 (1985).

55. See, e.g., ANSELL, supra note 22, at 69-71. 
level workforce constantly exercises discretion to depart from or supplement the rules as conditions dictate. ${ }^{56}$ Yet the moment frontline employees exercise this discretion, they go off the accountability grid, taking actions that are not publicly authorized; often are at odds with actions chosen by colleagues in similar situations; and sometimes are plainly incompetent, ill-advised, or in service of each employee's interests, not those of the agency or its clientele. ${ }^{57}$ Viewed from the perspective of conscientious street-level employees, bureaucracies excel at telling them how to treat likes alike but are not very good at helping them avoid treating unlikes alike. For that part of the job, the street-level employee is on her own, and she is damned if she does (deviate from prescribed steps) and damned if she doesn't (ignore rules that clearly are mismatched to the situation) ${ }^{58} \mathrm{~A}$ frequent result in such cases is perhaps the worst one: the employee does nothing at all. ${ }^{59}$

The accountability problem becomes even more acute when a specialinterest group disproportionately influences an agency's policies on behalf of frontline workers. In that situation, the likely result of bargained-for civil service regulations, collective bargaining agreements, and standard operating procedures is the proliferation of rules immunizing workers who follow prescribed rules, constraining supervision, and (through due process regulations) limiting sanctions for

56. See, e.g., LIPSKY, supra note 53, at 15 (linking need for street-level discretion to situations requiring "responses to the human dimensions"); Steven Maynard-Moody \& Michael Musheno, State Agent or Citizen Agent: Two Narratives of Discretion, 10 J. Pub. ADMIN. RES. \& THEORY 329, 334 (2000) ("[N] early every aspect of street-level work is defined by rules and procedures...., yet rules and procedures provide only weak constraints on and loose parameters around street-level judgments.").

57. See, e.g., John Brehm \& Scott Gates, Working, Shirking, and Sabotage: Bureaucratic Response to a Democratic Public 111 (1997) ("[S]ubordinate noncompliance ... when rules are contradictory, when client groups are in conflict, or when policies require interpretation ... [may be] motivated by policy-oriented reasons, running counter to official department policy."); LIPSKY, supra note 53, at 95 ("A visit to the waiting room of a welfare office in any inner-city neighborhood is likely to convey the impression that the Welfare Department assumes recipients have nothing else to do with their time."); WILSON, supra note 54, at 84 (describing considerations affecting police officers' decision whether to make an arrest: "Am I getting near the end of my tour of duty? Will I have to go to court on my day off?").

58. See, e.g., LIPSKY, supra note 53, at 72-73 ("The organization seeks to treat all clients equally...; the advocate seeks to secure special treatment for individual clients."); WiLSON, supra note 54, at 53 (explaining that police officers prefer other assignments over patrol work because they provide "clearer, less ambiguous objectives" and do not require "hard-to-defend judgments about what people deserve").

59. For policing examples, see, for example, Steven MAYnARD-Moody \& Michael Musheno, Cops, Teachers, Counselors: Stories from the Front Lines of Public Service 99-101 (2003) (declining to file charges against small-time drug dealer involved in a shooting who "wasn't a bad guy" and was "doing the best he could"); WILSON, supra note 54, at 210 (police treatment of speeders). 
bad behavior ${ }^{60}$ Such steps make it all the more difficult for employees to exercise discretion in service of the agency's or its clients' interests and for the agency to discipline employees who exercise discretion incompetently or self-servingly. ${ }^{61}$ Like the capture of regulatory agencies by regulated interest groups, the dominance of agency agendas by special-interest groups representing street-level bureaucrats gives the targets of bureaucratic accountability control over the terms of their own regulation.

These distortions frequently arise in urban public education, where teachers, principals, and other employees are well organized, students (the main "clientele") are not, and parent organizations have the same uneven impact as special-interest politics generally. ${ }^{62}$ Without question, the strongest voice in urban public education belongs to unions and other associations of frontline workers: teachers, principals, and in some places custodians, bus drivers, and others. ${ }^{63}$ These organizations have powerful incentives to protect the interests their respective members hold in common, chief among which are members' collective compensation, job security, workplace conditions, and protection from discipline in regard to their exercise of discretion on the job. Conversely, these associations have strong incentives to downplay interests as to which their members might disagree-including individual compensation, job security, workplace conditions, and recognition for how well or poorly they exercise discretion-not to mention the divergent interests of non-

60. See, e.g., Terry M. Moe, SpeCial InTERest: Teachers Unions ANd America's Publid SCHOOLS 175-79 (2011) (claiming that distortions generated by collective bargaining process prioritize union interests over student outcomes); Martin H. Malin, The Paradox of Public Sector Labor Law, 84 IND. L.J. 1369, 1380-81 (2009) (citing Milwaukee Public Schools' 232-page collective bargaining agreement with teachers with "more than 2,000 additional supporting documents" and New York City "contract of more than 200 pages, coupled with side agreements and state laws, 'determin[ing] nearly every aspect of what a teacher does, and does not do"').

61. See Al Shanker Speaks on Unions and Collective Bargaining, 16 Pew F. ON Educ. REFORM 34, 35-37 (1997).

62. See, e.g., Richard D. Kahlenberg \& Jay P. Greene, Unions and the Public Interest: Is Collective Bargaining for Teachers Good for Students?, 12 Educ. NEXT 60, 65 (2012) ("The normal process of checks and balances among competing interest groups, however, has failed when it comes to education.").

63. See Michael Hartney \& Patrick Flavin, From the Schoolhouse to the Statehouse: Teacher Union Political Activism and U.S. State Education Reform Policy, 11 ST. PoL. \& PoL'Y Q. 251, 251-59 (2011); see also Diane Ravitch, The Great School Wars: New York City, 1805-1973, at 214-18 (1974) (providing case study of failure of "space-saving, money-saving plan" for NYC schools at the hands of partisan groups allied with political machine); Johnny Ray Youngblood, Under Mayor's Control, the Schoolkids Are Doing All Right, N.Y. DAiLy News (Feb. 8, 2009, 9:35 AM), http://www.nydailynews.com/opinion/mayor-control-schoolkidsarticle-1.390709 (referencing the New York City Board of Education of the 1990s and before as "tantamount to a jobs program" and a "massive, consolidated hiring hall"). 
member students, parents, and taxpayers. This is not to say that organizing by public workers to protect their collective interests does more harm than good. But four attributes of teachers' and other public education unions tend to undermine bureaucratic accountability.

First, there is no reason to expect union members' collective interests to coincide with those of the schools' main clientele: children. ${ }^{64}$ On the contrary, shared employee interests are almost always too narrow to drive educational policy that is effective, especially for poor and minority students and families. ${ }^{65}$ Understandable teacher preferences that appear to conflict with the interests of lower-performing students include shorter work days and years; lock-step pay dependent on seniority rather than pedagogical effectiveness or need; and senior teachers' right to "bump" into open positions in more desirable schools, whether or not their skills and dispositions match the educational needs of children there. ${ }^{66}$

Testing policy is another example. Teachers often mistrust standardized tests, which they perceive as distractions from their real

64. See Bob Chanin, Gen. Counsel, NEA, Farewell Address at NEA 2009 Representative Assembly Meeting, YouTuBE (July 6, 2009), http://www.youtube.com/watch?v=bqn1rvv7Fis (acknowledging that the nation's largest teachers' union and its "affiliates are effective ... because we have power" and "not because" of the union's "vision of a great public school for every child," "care about children," "creative ideas," or "merit[orious] . . positions"); see also Geoff Decker \& Patrick Wall, Making His Case, Mulgrew Says New Contract Draws Battle Lines in "War with the Reformers," СнALKBEAT (May 8, 2014), http://ny.chalkbeat.org/2014/05/08/making-his-casemulgrew-says-new-contract-draws-battle-lines-in-war-with-the-reformers (describing leaked recording of union leader explaining to members that he had convinced the state education department, over objection of local reform officials, to require a convoluted rating rubric for teachers to "gum up the works," even though the simpler rubric local officials advocated was more beneficial to teachers).

65. See Johnson, supra note 36, at 139 ("[W]hile formal bargaining is effective for specifying narrow work rules, it is impractical for resolving complex problems, defining new programs, or making ongoing programmatic decisions.").

66. See, e.g., Emma Brown, D.C. Chancellor Kaya Henderson's Effort to Lengthen School Day Faces Union Resistance, WASH. PosT (June 29, 2014), http://www.washingtonpost.com/ local/education/dc-chancellor-kaya-hendersons-effort-to-lengthen-school-day-faces-unionresistance/2014/06/29/0b7e4ea0-fe30-11e3-8176-f2c941cf35f1_story.html ("Henderson set aside \$5.1 million to add an hour of instruction at 42 more schools for the 2014-15 school year, but at almost all of those schools, teachers either voted against adopting the longer day or union members prevented the issue from coming up for a vote."); Bumping in Schools, N.Y. TIMES (Dec. 27, 2006), http://www.nytimes.com/2006/12/27/opinion/27wed3.html ("The United States has a long and shameful history of dumping its least effective, least qualified teachers into the schools that serve the neediest children . . . [and] basically guarantee[ing] senior teachers the right to change schools whenever they want ...."); Monica Davey, Chicago's Mayor Challenges Teachers Union, N.Y. TiMES (Sept. 17, 2011), http://www.nytimes.com/2011/09/18/us/politics/ rahm-emanuel-angers-teachers-union-over-longer-school-day.html (describing union resistance to a proposal "to pay [Chicago] teachers 2 percent more to teach 90 minutes longer each day"). 
work and fear will be used to measure their effectiveness. ${ }^{67}$ To the extent teachers tolerate tests, they tend to prefer ones that reflect students' current academic status, not pupils' longitudinal academic growth, though status measures are largely a function of wealth while growth measures better reflect teaching quality. ${ }^{68}$ This preference reinforces the result of the combination of seniority-based lockstep pay and bumping rights: the aggregation of the most effective teachers in middle-class schools with higher-performing students. Unable to compete for compensation based on merit or service to the most challenging students, these teachers compete for better working conditions, bumping into schools in safer neighborhoods where relatively wealthy and privileged students begin school already scoring well on status-based tests. ${ }^{69}$ As attractive as this set of policies may be for teachers and the small subset of relatively privileged parents capable of effective organization, it is disastrous for poor and minority families. ${ }^{70}$

Second, teachers and school employees are the only broad-gauged constituency in public school systems able to organize effectively to protect collective interests. Teachers feel the immediate effects of policy changes, while taxpayers are at a distance from the changes and do not necessarily see or understand their impact. ${ }^{71}$ Students likewise have little capacity to offset the power of unions, given their youth, transience as

67. See, e.g., Robert Hach, Why I Hate Standardized Tests: A Teacher's Take on How to Save Public Education, SALON (Sept. 13, 2014, 4:00 PM), http://www.salon.com/2014/09/13/ why_i_hate_standardized_tests_a_teachers_take_on_how_to_save_public_education.

68. See, e.g., Amy J. Orr, Black-White Differences in Achievement: The Importance of Wealth, 76 Soc. EDUC. 281, 281-82 (2003) (identifying wealth as a key contributor to test score gaps); W. James Popham, Why Standardized Tests Don't Measure Educational Quality, 56 EDUc. LEADERSHIP 8, 12 (1999) (arguing that standardized test results focused on student proficiency levels conflate socioeconomic status and performance).

69. See, e.g., Dan Goldhaber et al., Uneven Playing Field? Assessing the Teacher Quality Gap Between Advantaged and Disadvantaged Students, 44 Educ. ReSEARCHER 293, 293-94 (2015) (discussing the research and reporting study results linking maldistribution of effective teachers to labor practices).

70. Daniel Weisberg et al., The New Teacher Project, The Widget Effect: Our

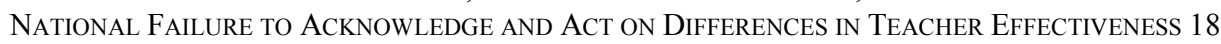
(2009), http://widgeteffect.org/downloads/TheWidgetEffect.pdf ("[P]oor and minority children, who have the greatest need for effective teachers, are least likely to get them."); Richard J. Murnane \& Jennifer L. Steele, What Is the Problem? The Challenge of Providing Effective Teachers for All Children, 17 FUTURE CHILD. 15, 28-29 (2007) ("New York State schools serving high concentrations of poor, nonwhite, or low-achieving children were disproportionately staffed by teachers who were inexperienced, ... had graduated from non-competitive colleges, or had failed their licensing examination on the first attempt.").

71. See, e.g., Kahlenberg \& Greene, supra note 62 , at 65 (arguing that parents and students with interests different from teachers' cannot check power of teachers' unions, which organize more effectively given their physical concentration in school buildings and better grasp of school policy). 
they move through grades and schools, and diffuse interests.

The third problematic attribute of educator unions is that the streetlevel bureaucrats whose common interests they represent are the main focus of the agencies' bureaucratic accountability. As a result, the disproportionate influence unions exercise threatens the agencies' democratic bona fides by aggravating the unaccountability of street-level discretion.

Finally, teachers' unions, like other interest groups, survive only by coalescing member-contributed resources around "lowest common denominator" interests shared by all members. Consequently, unions resist initiatives that weaken solidarity among members or violate hierarchical or other core bureaucratic principles, even if they would benefit most members or serve higher values. Unions' resistance to teacher evaluations are an example. Although evaluations benefit students without harming most teachers (who are effective enough that evaluations do not threaten their jobs), the risk evaluations pose to a small subset of teachers is enough to garner strong union opposition. ${ }^{72}$

Similar concerns lead unions to oppose evaluative techniques that increase reliability, accuracy, and efficiency. For example, although peer review can enhance the validity and reliability of traditional review by principals alone, help teachers learn from one another, and expand the number of available reviewers while limiting the demands placed on each, unions oppose peer review as harmful to worker solidarity. ${ }^{73}$ Unions likewise oppose highly reliable student surveys of teacher quality as contrary to the hierarchical status of students as subordinates. ${ }^{74}$ In short, teachers' unions are effective advocates on issues on which most teachers' interests are aligned. They are not nearly as effective at representing the differentiated needs of their members and have no mission to represent needs of children that differ from teachers' collective interests.

72. See Bill \& Melinda Gates Found., Ensuring Fair and Reliable Measures of EfFective Teaching: Culminating Findings from the MET Project's Three-Year Study 20 (2013), www.metproject.org/downloads/MET_Ensuring_Fair_and_Reliable_Measures_Pract itioner_Brief.pdf; Lois Weiner, Teacher Unionism Reborn, NEW POL., Winter 2012, $\mathrm{http}: / /$ newpol.org/content/teacher-unionism-reborn.

73. See, e.g., Susan M. Johnson et al., Ctr. for Am. Progress, Teacher to Teacher: Realizing the Potential of Peer Assistance And Review 9-12, 16 (2010), https://www.americanprogress.org/wp-content/uploads/issues/2010/05/pdf/par.pdf.

74. Geoff Decker, Student Surveys Seen as Unlikely Evaluations Element, for Now, CHALKBEAT (Nov. 28，2012), http://ny.chalkbeat.org/2012/11/28/student-surveys-seen-asunlikely-addition-to-evaluations-for-now (reporting that although "student feedback and teacher observations combined ... more closely correlate[] with teacher effectiveness than observations alone," unions "staunchly oppose[] incorporating student feedback" because students should not "make high-stakes decisions about their teachers"). 
Nor do parent organizations impose much accountability on education bureaucracies, given families' divergent interests and the uneven distribution of political influence among them. To be sure, well-educated, non-working parents sometimes do exercise outsized influence in schooland district-based parent groups. ${ }^{75}$ But these parents typically represent the interests of more privileged, initially higher-performing children for whom public schools are stepping stones to prestigious colleges rather than the primary venue for learning. For these parents, the ideal situation is a school dominated by their children's academic peers, in which "proficiency" measures entirely correlated to wealth and parent education are collected just frequently enough to mark the kids' and schools' academic superiority and enhance their access to the next similar school up the line, from pre-K to college. These parents understandably oppose frequent measures of student learning growth, which do not positively correlate to privilege and often show that the "best" schools in an area do less well by their students, potentially diminishing their status in the eyes of higher schools and colleges. Notably, the interests of these parents tend to align most fully with those of teachers' unions, cementing unions' outsized influence in public education politics.

By contrast, poor and minority parents typically work, often in multiple jobs, more often raise children singlehandedly rather than as couples, and may be less educated themselves, with less access to knowledge about established stairways to college. ${ }^{76}$ These parents must delegate to schools the job of guiding and monitoring their children's learning. For these parents, the ideal situation is a school in which children of a broader range of academic attainment are present and in which educators assess each child at the start and end of each year to measure longitudinal growth and mid-year to diagnose learning gaps and generate ongoing solutions. ${ }^{77}$ Equally important, these parents have less

75. Sabrina Tavernise, Education Gap Grows Between Rich and Poor, Studies Say, N.Y. Times (Feb. 9, 2012), http://www.nytimes.com/2012/02/10/education/education-gap-growsbetween-rich-and-poor-studies-show.html (reviewing research attributing "growing gap in achievement" to the fact "that wealthy parents invest more time and money than ever before in their children . . . , while lower-income families ... are increasingly stretched for time and resources").

76. See, e.g., Jennifer A. O’Day \& Marshall S. Smith, Quality and Equality in American Education: Systemic Problems, Systemic Solutions, in The DynAmics of OpPoRTUNITY IN AMERICA 297, 298-300 (Irwin Kirsch \& Henry Braun eds., 2016); Tavernise, supra note 75.

77. See Lisa Fleisher \& Sarah Armaghan, A Final Report for Schools, WALl ST. J. (Nov. 13, 2013, 10:04 PM), https://www.wsj.com/articles/a-final-report-for-schools-1384398247 (quoting parent discussing her preference for system for grading schools because it gave parents "some sense of safety . . . because you know that someone has looked at the school"); Yoav Gonen, Failing Schools Have Less to Fear Under de Blasio, N.Y. Post (Nov. 14, 2013, 2:17 AM), http://nypost.com/2013/11/14/failing-schools-have-less-to-fear-under-de-blasio (quoting 
time and fewer resources to devote to groups mobilized to support their interests. ${ }^{78}$ No wonder, then, that "parent" interest groups strongly oppose frequent testing ${ }^{79}$ and longitudinal-growth measures of student success, ${ }^{80}$ though surveys suggest poor and minority parents support these initiatives. ${ }^{81}$ The same dynamic explains why such groups do not support social and academic integration of schools and expend much of their social capital pursuing class-size reduction, which may make classes more pleasant for their children but - apart from very large, and therefore financially untenable, reductions in the earliest grades-has no statistically reliable connection to improved outcomes. ${ }^{82}$

\section{The Education Reform Response to Bureaucracy and Special-Interest Politics}

A desire to replace bureaucracy and special-interest politics has motivated waves of proposals to reform $\mathrm{K}-12$ education. ${ }^{83}$ In response,

New York City Mayor Michael Bloomberg explaining schools' focus on student outcome data as serving " $[\mathrm{p}]$ arents [who] don't have the ability to go and get down in the weeds and go through all the data").

78. See sources cited supra note 42.

79. See supra note 18 (citing parent opposition to testing).

80. Beth Fertig, Why Can't U Teach Me 2 Read? Three Students and a Mayor Put OuR SCHOOLS TO THE TEST 120 (2009) (documenting resistance by "parents at high-performing schools" to the use of growth measures to evaluate schools).

81. For example, on New York City's 2013 parent surveys, amid a huge middle-class outcry against standardized testing, when asked what improvement they would most like their school to make, 17 percent of parents chose " $[\mathrm{m}$ Jore preparation for state tests" (the second most popular of ten answer choices), while just 2 percent chose "less preparation for state tests" (the least popular answer choice). N.Y.C. DeP'T OF EduC., Citywide Question-BYQUESTION SURVEY RESUlTS FOR COMMUNITY SCHOOLS 5 (2013), http://schools.nyc.gov/NR/rd onlyres/7E2F3AD9-7E67-4A40-9280-30D7CBB9A502/0/2013SchoolSurveyCitywide ResultsforCommunitySchools.pdf (emphasis added).

82. See, e.g., Grover J. Whitehurst \& Matthew M. Chingos, Brown Ctr. on Educ. Pol'y at Brookings, Class Size: What Research Says and What It Means for State POLICY 5-11 (2011), https://www.brookings.edu/wp-content/uploads/2016/06/0511_class_size _whitehurst_chingos.pdf; see also Christopher JePSEN \& STEVEn Rivkin, Pub. PoL'y InST. OF Cal., Class Size Reduction, Teacher Quality, and Academic Achievement in California Public ElEMENTARY SCHOOls 4, 23 (2002), http://www.ppic.org/content/pubs/report/R 602CJR.pdf (finding that California's 1990s class-size-reduction efforts resulted in an influx of ill-prepared teachers who disproportionately ended up in schools for poor and minority children and associating those events with declines in achievement by those children); Miriam Seifter, Second-Order Participation in Administrative Law, 63 UCLA L. REv. 1300, 1333-53 (2016) (questioning ability of established interest groups to represent needs of many poor and minority individuals in administrative rulemaking).

83. See ChubB \& MoE, supra note 22, at 3 ("[E]xisting [bureaucratic] institutions cannot solve the problem, because they are the problem .... [T] he key to better schools is institutional reform." (emphasis omitted)); Raywid, supra note 22, at 153 ("[B]ureaucracy has been criticized 
some of the largest school districts across the country and a number of state education departments have replaced bureaucracies with more flexible governance structures designed to support newly empowered field-level educators to improve student outcomes. ${ }^{84}$ As this Section develops, however, these changes are puzzlingly incomplete in a number of respects.

\section{Education Reform in General}

Partly to reduce the power that central administrators, geographically deployed supervisors, and citywide and community-based interest groups exerted over lay school-board members and transient superintendents, many cities have fundamentally altered school governance by giving the mayor ultimate authority over school boards, superintendents, and the bureaucracy. ${ }^{85}$ This has occurred in Baltimore, Boston, Chicago, Cleveland, Harrisburg, Hartford, Indianapolis, New Haven, New York City, Oakland, Philadelphia, Providence, and Washington, D.C., among other districts. ${ }^{86}$ In addition to aggregating responsibility and political accountability in one highly visible executive, ${ }^{87}$ this arrangement

as inefficient[,] . . . ineffective[,] . . . inhumane, unresponsive to its clients or to the rest of the public, dominated almost entirely by technological and territorial imperatives, largely out of control, and blind and impervious to the need for change."); JEFFREY R. HENIG \& WILBUR C. RICH, Mayors in the Middle: Politics, Race, and Mayoral Control of Urban Schools 6 (2004).

84. See Richard F. Elmore, Introduction: On Changing the Structure of Public Schools, in ELMORE, supra note 22, at 1, 11 (associating school-reform proposals with "changes in the distribution of power between schools and their clients, or in the governance structure within which schools operate," which in turn affect "the way teaching and learning occur" and "conditions of entry and licensure of teachers and administrators, and school structure, conditions of work, and decision-making processes within schools"); OUCHI, supra note 9, at 25-28.

85. See, e.g., Kenneth K. Wong \& Francis X. Shen, Ctr. For Am. Progress, Mayoral Governance AND Student ACHievement: How Mayor-Led Districts ARe Improving SCHOOL AND StUdent PeRformance 7-8 (2013), http://americanprogress.org/issues/education/ report/2013/03/22/56934/mayoral-governance-and-student-achievement/.

86. Id. at $7-9$.

87. For example, in 2004, New York City Mayor Bloomberg fired two appointees to a panel with decision-making authority over the schools and engineered the departure of a third after they opposed his plan to impose test-score-based promotion requirements for third graders. MICHAEL Fullan \& Alan Boyle, Big-City SChOOl ReForms: Lessons FROM NEW York, TORONTO, AND LONDON 28-29 (2014). Bloomberg declared:

This is what mayoral control is all about .... In the olden days, we had a board that was answerable to nobody. And the Legislature said it was just not working, and they gave the mayor control .... They are my representatives, and they are going to vote for things I believe in.

David M. Herszenhorn, Bloomberg Wins on School Tests After Firing Foes, N.Y. TIMES (Mar. 16, 2004), http://www.nytimes.com/2004/03/16/nyregion/bloomberg-wins-on-school-tests-afterfiring-foes.html. 
broadens the range of political constituencies that the responsible official must satisfy, making it more difficult for any special interest to dominate. ${ }^{88}$ This increases the mayor's ability to take a systematic and strategic approach to improving student results and to shake up inefficient and patronage-driven decision-making. ${ }^{89}$ This change can, however, engender resentment because it subordinates locally accessible and school-specific opportunities for civic and political engagement to a single, infrequent, city-wide, multi-focal mayoral election. ${ }^{90}$

Another common governance change has been to "empower" individual school leaders and teachers to make core managerial and instructional decisions that previously resided with the central bureaucracy. This decentralization may seem to run counter to mayoral control, but the motivations are the same. Both limit the power of the central bureaucracy operating at a distance from the multifaceted problems of and diverse populations served by public education. Both also diminish the sway of special-interest allies to orient solutions to their own needs. Finally, both locate day-to-day authority in the hands of professionals with the best information about their clients' particularized needs. ${ }^{91}$ In place of compliance with input-based rules adopted centrally and enforced hierarchically, these regimes use elaborate systems of outcome measures for schools and educators in conjunction with "heterarchical" networks of schools, collaborative "inquiry teams" of educators acting within and across schools, and problem-oriented "facilitators" to hold educators accountable both "externally" and "internally." "92

88. $C f$. The Federalist No. 10 (James Madison) ("Extend the sphere, and you take in a greater variety of parties and interests; you make it less probable that a majority of the whole will have a common motive to invade the rights of other citizens; or if such a common motive exists, it will be more difficult for all who feel it to discover their own strength, and to act in unison with each other.").

89. See OuchI, supra note 9, at 19-21, 147, 155-64 (discussing school reforms in New York and Chicago).

90. See, e.g., Jeffrey Henig et al., Parent and Community Engagement in New York City and the Sustainability Challenge for Urban Education Reform, in EDUCATION REFORM IN NEW York City: Ambitious Change In the Nation's Most Complex SCHOOL System 38 (Jennifer A. O'Day et al. eds., 2011) ("Much of the mayoral control battle . . . center[ed] on the issue of whether the chance to vote every four years in general elections in which those without a direct stake in the schools also participate provides parents with a sufficient opportunity to influence policies and priorities.”).

91. See OuchI, supra note 9, at 125-40 (school empowerment in New York); id. at 177-81 (decentralization in Houston); id. at 230-36 (autonomous schools in Chicago).

92. External accountability uses measures and targets set by central actors enforced through rewards and consequences to evaluate and influence behavior in schools. Internal accountability operates by force of school professionals' collective sense of responsibility for improving the transparent results of their individual and collaborative actions. See, e.g., Stacey Childress et al., 
These new governance structures transform central education agencies. What previously were deciders and implementation micromanagers become assemblers of a "portfolio" of differentiated schools (often combinations of "traditional public" and charter schools) $;{ }^{93}$ defenders of school-level flexibility $;{ }^{94}$ distributors of resources (typically on a per-pupil basis weighted by the instructional challenge categories of students present) ${ }^{95}$ compilers of data and facilitators of its use to support local improvement efforts; ${ }^{96}$ and enforcers of accountability for improvements in student learning as demonstrated through tests, credit accumulation, rates of promotion to higher grades and of graduation, and demonstrated readiness for college and careers. ${ }^{97}$

Managing for Results at the New York City Department of Education, in EDUCATION REFORM IN NEW YoRK CiTY, supra note 90, at 87, 92-94 (describing a productive tension between external and internal accountability and different ways of balancing the two); Andrew Hargreaves \& Michael Fullan, The Power of Professional Capital, JSD, June 2013, at 36, 39 (describing internal accountability through collaborative inquiry in which "[t]eachers sit together with the transparency of the data, and all teachers take collective responsibility for all children across grades"). Compare ERIC NAdelstern, 10 Lessons from New York City Schools: What REALLy WorKS to IMPROVE EDUCATION 19-31 (2013) (extolling external accountability), and infra notes 127-30, 133-34 and accompanying text (describing NYC's substantially external accountability measures), with FULLAN \& BOYLE, supra note 87, at 67-68 (praising reforms that downplay accountability via "prescription and top-down mandates" and foster internal responsibility), and Mike Schmoker, Tipping Point: From Feckless Reform to Substantive Educational Improvement, PHI DELTA KAPPAN, http://mikeschmoker.com/tipping-point.html (last visited May 20,2017) (preferring internal accountability through "strong professional learning communities").

93. Hill ET AL., supra note 2, at 11-12; Paul T. Hill, Leadership and Governance in New York City School Reform, in EduCATION ReForm IN NEW York City, supra note 90, at 17, 26 [hereinafter Hill, Leadership and Governance]; CAMPBELL \& GROsS, supra note 2, at 5.

94. NADELSTERN, supra note 92, at 16 ("[P]rincipals, in consultation with teachers [and] parents, ... made the important decisions ... that [previously] had typically been determined in the Central Office."); Hill, Leadership and Governance, supra note 93, at 20 (describing the "Klein/Bloomberg" approach which "let local productive units (schools) make the consequential decisions that affect their productivity").

95. See, e.g., Leanna Stiefel \& Amy Ellen Schwartz, Financing K-12 Education in the Bloomberg Years, 2002-2008, in EdUCATION ReFORM IN NEW York CiTy, supra note 90, at 55, 61-62 (listing Fair Student Funding determinants, including "need weights" such as poverty and below-standard achievement and "portfolio weights" such as Career and Technical Education schools and transfer schools).

96. See infra notes $129,140-41,162-66$ and accompanying text.

97. See FerTiG, supra note 80, at 50 ("Klein and Bloomberg enacted a controversial plan to stop promoting elementary children to the next grade if they didn't pass the statewide tests."); Childress et al., supra note 92, at 95 (describing school progress reports measuring "school environment, student performance, student progress, and additional credit"). 


\section{Education Reform Examples}

Although contested, ${ }^{98}$ the results of recent reforms along these lines in a number of urban U.S. school districts appear promising. This Subsection provides some examples.

\section{a. Moderate Steps: Houston, Boston, Charlotte-Mecklenberg, and Denver}

An early example of reform is the Houston Independent School District. Starting in 1992, Houston's reform-minded school board increased principal autonomy and management training, implemented performance bonuses for teachers, ${ }^{99}$ and established Shared DecisionMaking Committees comprising teachers, parents and community representatives to advise the principal on issues such as budget, curriculum, staffing, and school organization. ${ }^{100}$ In 2005, Houston adopted a "Board Monitoring System," requiring regular superintendent reports on "academic progress, operational effectiveness, public and employee support, and facility management."101 The results have been promising, with significant improvements on state test scores and school ratings. Between 2005 and 2011, the number of district schools rated exemplary by the state increased from six to fifty-nine, and the number of academically unacceptable schools declined from thirty-four to fifteen. ${ }^{102}$

A second example is the transformation of the Boston public schools, beginning when Mayor Raymond Flynn gained control over the district in 1992 and continuing through Mayor Thomas Menino's five subsequent terms. ${ }^{103}$ Indicative of the changes that were implemented was the creation of empowered "Pilot Schools" freed from various union work rules and given more control over budget, staffing, curriculum,

98. See Fullan \& Boyle, supra note 87, at 57 (characterizing evidence of increased performance trends in New York City as "debatable"); Did NYC Close the Achievement Gap in a Decade of Mayoral Control?, DiAne Ravitch's Blog (Nov. 3, 2012), http://dianeravitch.net/ 2012/11/03/did-nyc-close-the-achievement-gap-in-a-decade-of-mayoral-control ("Despite a decade of relentless emphasis on testing, accountability and choice, the achievement gap has barely budged.").

99. See OuCHI, supra note 9, at 166-67.

100. Id. at 168 .

101. Id. at 166 .

102. See id. at 170; Press Release, Hous. Indep. Sch. Dist., Ninety-One Percent of HISD Schools Meet Tougher Texas Standards (July 29, 2011), http://www.houstonisd.org/cms/lib2/ TX01001591/Centricity/Domain/7946/HISDTougherStandards.pdf_PR.pdf.

103. See Wong \& SHEN, supra note 85, at 7; Katharine Q. Seelye, Thomas M. Menino, Mayor Who Led Boston's Renaissance, Is Dead at 71, N.Y. TIMES (Oct. 30, 2014), https://www.nytimes.com/2014/10/31/us/thomas-m-menino-mayor-who-transformed-bostondies-at-71.html. 
governance, and scheduling. ${ }^{104}$ The district shored up accountability by evaluating schools against consistent benchmarks every five years. ${ }^{105}$ From 1999 to 2010, the percentage of Boston tenth graders scoring proficient or better on the Massachusetts Comprehensive Assessment System increased from 19 to 60 percent in English language arts and from 15 to 60 percent in mathematics, though the gains have tapered off more recently. ${ }^{106}$

In 2007, the Charlotte-Mecklenburg school district implemented a similar turnaround strategy using monetary incentives and a promise of broad school-based decision-making authority to induce strong leaders and teachers to work in the district's most at-risk schools. ${ }^{107}$ Simultaneously, the district deployed a sophisticated combination of lagging, outcome-focused, and leading, often qualitative, indicators and a comprehensive data system to hold schools accountable and provide educators with diagnostic information about the students, classrooms, subject matters, and schools needing the most attention. ${ }^{108}$ The result was significant improvement in both reading and math outcomes on annual North Carolina End-of-Grade tests. ${ }^{109}$ From 2007-2008 to 2011-2012, students at schools participating in the school-empowerment program had longitudinal growth rates in math and reading 12 and 13 percent higher, respectively, than students at non-participating schools. ${ }^{110}$ According to one close observer of Charlotte-Mecklenburg's efforts to improve student outcomes, its reforms succeeded without some of the deeper structural changes employed elsewhere because of the unified commitment of the school board and superintendent, in the absence of a strong union, to giving themselves and school leaders the "flexibility to

104. Ctr. For Collaborative Educ., Strong Results, High Demand: A Four-Year StUdy of Boston's Pilot High Schools iv (2007), http://cce.org/files/StrongResults_Study_ 2007.pdf.

105. Id. at v. In return for this accountability, the district increased educator autonomy by letting " $[t]$ eachers evaluate baseline data, identify student needs, project student growth targets, and provide rationales for their decisions ... [and] seek and plan the most effective instructional strategies to meet identified student needs and establish an appropriate interval of instructional time.” Cmty. Training \& Assistance Ctr., It's More Than Money 29 (2013), http://ctacusa.com/wp-content/uploads/2013/11/MoreThanMoney.pdf.

106. Compare WONG \& SHEN, supra note 85, at 20 (documenting gains for fourth- and eighth-grade students in both subjects), with id. at 26 ("Boston has not quite kept up its momentum ....").

107. Cmty. Training \& Assistance CTR., supra note 105, at 14.

108. Id. at 29 (describing district's trade of accountability for educator autonomy to "evaluate baseline data, identify student needs, project student growth targets," "plan the most effective instructional strategies to meet identified student needs," and "provide rationales for their decisions").

109. See id. at 62-63.

110. Id. at 63 . 
incentivize, rank, improve, and remove" principals and teachers. ${ }^{111}$

In 2009, Denver introduced a more extensive set of "portfolio" reforms, including enhanced local decision-making flexibility for new charter schools as well as for principals of traditional public schools, enhanced school choice for families, compensation and hiring decisions based on educators' demonstrated classroom results, a sophisticated scorecard for holding schools accountable, and closures of both traditional and charter schools based on scorecard results. ${ }^{112}$ These changes were accompanied by improved outcomes, with the number of schools receiving the highest grade increasing from nine in 2009 to fifteen in 2012 and with the district's on-time graduation rate increasing 22 percent between 2006 and 2014. ${ }^{113}$

Denver's early results under Colorado's Innovation Schools initiative are also promising. Under this program, a school may apply for Innovation status, which waives bureaucratic state and district mandates that tend to hamper school-improvement efforts. ${ }^{114}$ Although most Denver schools that obtained Innovation status were poorly performing at first, with student proficiency rates well below the state average, their students' longitudinal growth rates in reading, writing, and math exceeded the state median after the schools obtained Innovation status. ${ }^{115}$ Teachers' ratings of their own decision-making ability, capacity, ownership, empowerment, and ability to innovate - thought to be leading indicators of student results_-have also been higher in Innovation schools than in traditional schools. ${ }^{116}$

111. Heather Zavadsky, School Turnarounds: The Essential Role of Districts 79 (2012).

112. Id. at $117-20,123-29$.

113. See Karen Augé, More Denver Public Schools Making the Grade, District Reports, Denver Post (Sept. 24, 2012, 9:42 AM), http://www.denverpost.com/ci_21620850/more-dpsschools-making-grade-district-reports; Jonah Edelman, What It Takes to Fix American Education, DAILY BEAST (Nov. 23, 2014, 6:45 AM), http://www.thedailybeast.com/articles/2014/11/ 23/what-it-takes-to-fix-american-education.html; Jeremy P. Meyer, Only Handful of Schools Earn DPS's Top Ranking, DENVER Post (Sept. 17, 2009, 2:38 PM), http://www.denverpost.com/ 2009/09/17/only-handful-of-schools-earn-dpss-top-ranking.

114. See Innovation Schools, Colo. DeP'T EdUC., https://www.cde.state.co.us/choice/ innovationschools (last visited Apr. 11, 2017).

115. Susan ConNors et al., Univ. of Colo. Denver, InNovation Schools in DPS: Year THREE OF AN EvaluATiOn StUdy 18-19 (2013), http://apluscolorado.org/wp-content/uploads/ 2016/08/Innovation-Schools-in-DPS-Year-Three-of-an-Evaluation-Study.pdf.

116. Id. at 6 . 


\section{b. All-Out Reform: New York City, 2002-2013}

In a number of large cities, including Chicago, Los Angeles, New York, and Washington, D.C., legislation establishing mayoral control ${ }^{117}$ triggered still more comprehensive changes. These included the appointment of ambitious, reform-minded superintendents; ${ }^{118}$ rigorous learning standards culminating in early adoptions of the Common Core ${ }^{119}$ enhanced autonomy for schools in deciding how to meet standards $;{ }^{120}$ stronger accountability for whether they did; ${ }^{121}$ changes in leadership or closure of chronically underperforming schools; family choice among schools, including charter and other new schools committed to higher performance; ${ }^{122}$ principal and teacher evaluation and rewards based substantially on student outcomes; ${ }^{123}$ and technology systems rich in diagnostic data and tools for informing the public, parents, administrators, and teams of educators trained to conduct structured "inquiry" into causes and cures for weak gains for particular schools,

117. See Wong \& SHen, supra note 85 , at $7-8$.

118. Sharon Otterman \& Jennifer Medina, New York Schools Chancellor Ends 8-Year Run, N.Y. TIMES (Nov. 9, 2010), http://www.nytimes.com/2010/11/10/nyregion/10klein.html (discussing tenure of Joel Klein, who "presided over a radical reorganization of the New York City school system," including "increasing parent choice through innovations like charter schools, weakening traditional union protections like tenure and bringing numbers-based accountability to schools"); Kate Pickert, Obama's White House: Education Secretary Arne Duncan, TIME (Dec. 2, 2008), http://content.time.com/time/specials/packages/article/0,28804,1863062 1863058_1867011,00.html (describing Chicago schools chief Arne Duncan as "not shy[ing] away from controversy... [and] clos[ing] failing schools" while strongly advocating "for charter schools [and] performance pay for teachers"); Amanda Ripley, Rhee Tackles Classroom Challenge, TIME (Nov. 26, 2008), http://content.time.com/time/magazine/article/ $0,9171,1862444,00 . h t m l$ (profiling Rhee, who "promised to make Washington the highestperforming urban school district in the nation").

119. "The Common Core State Standards Initiative is a state-led effort that established a single set of clear educational standards for kindergarten through 12th grade in English language arts and mathematics that states voluntarily adopt." Frequently Asked Questions, COMmON CORE St. Standards Initiative, http://thompson.k12.co.us/Page/3844 (last visited Apr. 11, 2017).

120. OuCHI, supra note 9, at 233 (describing school autonomy in Chicago); Hill, Leadership and Governance, supra note 93, at 22 ("[New York City's chancellor] Klein ... came down on the side of autonomy as a precondition for reform."); Autonomy, Focus DC (2010), http://focusdc.org/autonomy ("DC's strong public charter school law ... provides an unusual amount of autonomy to the District's public charter schools. . . . [This autonomy extends to] instruction, expenditures, administration, and personnel.").

121. See, e.g., FERTIG, supra note 80, at 117-18; NADELSTERn, supra note 92, at 21; OUCHI, supra note 9, at 92-97; Childress et al., supra note 92, at 97.

122. See infra note 129 and accompanying text.

123. Robert J. Shapiro \& Kevin A. Hassett, The Economic Benefits of New York City's Public School Reforms, 2002-2013, at 4-5 (2013), http://www.sonecon.com/docs/ studies/Report_on_Economic_Benefits_of_NYC_Educational_Reforms-Shapiro-Hassett-FinalDecember2013.pdf. 
classrooms, and categories of or individual children. ${ }^{124}$ The changes were accompanied by substantial, though incomplete, improvements in student outcomes. $^{125}$

This Subsection focuses on perhaps the most far reaching reforms, in New York City from 2002 to 2013. ${ }^{126}$ Exchanging autonomy for accountability, Mayor Michael Bloomberg and Chancellor Joel Klein increased the control principals exercised over hiring and firing teachers, setting the school's budget and daily schedule of classes and teacher assignments, choosing the school's portfolio of professional and youth development programs, and designing its curriculum. By grading schools A-F, the reforms held principals accountable for using their autonomy to help students attain average annual longitudinal gains on state assessments comparable to or better than the highest levels achieved by city schools with similar populations in the recent past. ${ }^{127}$ As "leading indicators," principal accountability also included annual parent, teacher, and student Learning Environment Surveys and expert Quality Reviews of the rigor with which each school identified its strengths and weaknesses, implemented a coherent strategy for improving its operations and outcomes, and adjusted its strategy based on feedback about results. ${ }^{128}$ The district closed chronically poor-performing schools

124. See N.Y.C. Dep't of Educ., The New York City Progress Report: ELEMENTARY/MIDDLE/K-8, at 3-4 (2013), http://schools.nyc.gov/NR/rdonlyres/7B6EEB8BD0E8-432B-9BF6-3E374958EA70/0/EducatorGuide_EMS_20131118.pdf(describing a "quality review" designed to measure how well a school is organized to support learning, and to gather statistical data and share information on student learning outcomes).

125. Emma Brown, D.C. Posts Significant Gains on National Test, Outpacing Nearly Every State, WASH. Post (Nov. 7, 2013), http://www.washingtonpost.com/local/education/dc-postssignificant-gains-on-national-test-outpacing-nearly-every-state/2013/11/07/dccc08c0-475c-11e3 -b6f8-3782ff6cb769_story.html; see also infra notes 141-150 and accompanying text (citing improvements in New York City).

126. Between 2006 and 2009, the lead author of this Article helped design and implement a number of the reforms discussed in this Subsection as head of the New York City Department of Education's Division of Accountability and Achievement Resources.

127. New York City schools were evaluated using a "peer rating" system, under which each school's outcomes were compared to those at the forty other schools in the system most like it, judged by students' incoming test scores and demographic make-up. N.Y.C. DEP'T OF EDUC., supra note 124, at 3-4 (describing peer-grouping methodology); see sources cited supra note 122. Three-fourths of a school's grade for a series of metrics was based on how close schools came to matching or surpassing the top-achieving school in their cohort over the prior three years; if a school surpassed that level, its performance became the benchmark for schools in future years. The remaining quarter of the grade was based on a comparison of the school's outcomes to those achieved over the past three years by all schools of its type (e.g., elementary schools) across the city. Accountability That Improves: An Interview with Jim Liebman, District MGMT. J., Spring 2014, at 4, 5 [hereinafter Accountability That Improves].

128. N.Y.C. DeP'T OF Educ., 2016-2017 QuALity Review Rubric (2017), http://schools.nyc.gov/NR/rdonlyres/8C11A001-7E78-469D-996F-B0C3703CEA81/0/ 
at which leading and lagging indicators were negative, replaced them with large numbers of charter and other new schools, ${ }^{129}$ and increased family choice among middle and high schools. ${ }^{130}$ Additionally, Bloomberg and Klein increased teacher salaries by 41 percent while working to recruit larger numbers of qualified teachers through Teach For America and a local Teaching Fellows Program ${ }^{131}$ — with the result that the number of uncertified teachers (who accounted for about half of all teachers hired between 1995 and 2002) dropped to zero by 2006, while entering teachers' SAT and qualification exam scores dramatically increased. ${ }^{132}$ Shortly thereafter, the district began evaluating teachers based on student longitudinal gains on state tests.

New York also worked to build capacity and foster internal accountability among educators at the school level. ${ }^{133}$ An important early step was the founding of a Leadership Academy to "recruit[] and prepare[] aspiring public school leaders to become principals in highneed NYC schools," where they were expected to take advantage of their expanded autonomy by accelerating student learning growth. ${ }^{134}$ By 2012 ,

201314QualityReviewRubric.pdf.

129. SHAPIRO \& HASSETT, supra note 123, at 4-5 (noting 2002-2013 increase in charter school enrollment from 1,800 to 60,000 ).

130. Id. at 4 ("The Bloomberg reforms also expanded school choice to all public school students and public high schools . . . B B 2008, incoming high school freshmen could choose from more than 700 schools."); Sean P. Corcoran \& Henry M. Levin, School Choice and Competition in the New York City Schools, in EdUCATION Reform IN New York CitY, supra note 90, at 199, 204 (describing choices available to middle school families).

131. See Goertz et al., Recruiting, Evaluating, and Retaining Teachers, in EdUCATION Reform in New York City, supra note 90, at 157, 166 ("The Teaching Fellows Program is highly selective, often attracting early career changers."); SHAPIRO \& HASSETT, supra note 123, at 2, 4 ("Real funding . . . rose from $\$ 15.4$ billion in 2002 to $\$ 24$ billion in 2013 . . . support[ing] 41 percent hikes in average teacher compensation.").

132. See, e.g., Fullan \& Boyle, supra note 87, at 41-42; Paul T. Hill, Bloomberg's Education Plan Is Working: Don't Ditch It, ATLANTIC (Oct. 22, 2013), http://www.theatlantic.com/education/archive/2013/10/bloombergs-education-plan-is-workingdont-ditch-it/280704 (finding "measures of teacher quality including math and verbal SAT scores, scores on teacher qualification exams, and attendance at competitive colleges, have increased dramatically since 2002").

133. See Childress et al., supra note 92, at 92 (“Accountability isn't entirely or even mainly about incentives. It's about capacity building, which to me means adult learning based on self and team evaluation of what's working and what's not, and knowledge management, meaning spreading what works from one student or school to another." (quoting Liebman)).

134. Fullan \& Boyle, supra note 87, at 42-43; see Philissa Cramer \& Rachel Cromidas, In a Change, City Is Steering Aspiring Principals off the Fast Track, ChalkBeat (Nov. 15, 2012), $\mathrm{http}: / /$ ny.chalkbeat.org/2012/11/15/in-a-change-city-is-steering-aspiring-principals-off-the-fasttrack (quoting former district official, Nadelstern, "The Leadership Academy said that until the [university-based education] schools produced reform-minded leaders capable of running challenging urban institutions then the district would step in and attempt to do the job themselves"). 
the Academy's Aspiring Principals Program had trained 17 percent of the City's approximately 1,700 principals. ${ }^{135}$

A key set of skills the Leadership Academy imparted to principals-intraining was how educators could use the expanding array of data generated by the district's new accountability system and other tools to improve operations and outcomes. One tool was a menu of no-stakes diagnostic assessments educators could administer periodically to track students' progress and identify points where students were struggling. ${ }^{136}$ Schools were also encouraged to develop their own assessments. ${ }^{137}$ Another new tool was the Achievement Reporting and Innovation System (ARIS), which collected evaluative and diagnostic data that were instantly available to educators, disaggregated down to the school, classroom, and individual student level. The system offered educators instructional materials and strategies developed locally and nationally. ${ }^{138}$

To help educators effectively use this information and build internal accountability, the district created a cadre of facilitators and comprehensive manuals ${ }^{139}$ to support "inquiry teams" in each of the system's schools. Comprising the principal, teachers, a "data manager," and other school personnel, inquiry teams implemented a flexibly structured process for (1) using available data to identify a "target population" of struggling students and the points at which the instruction they received broke down; (2) generating diagnostic information through "low inference" observation of the subjects' classwork and behavioral responses to instruction and using those data and other research to hypothesize causes of instructional failure and implement solutions; (3) setting short-term improvement goals and measuring progress toward them with brief, low-impact assessments; (4) spreading the use of successful strategies to teachers in the same and other schools; (5) identifying school-wide structural changes needed to support the new strategy; and (6) repeating the diagnostic process and revising initially adopted strategies if they continued to fail at least some of the focal

135. Fullan \& Boyle, supra note 87 , at 43.

136. Periodic Assessments, N.Y.C. DeP'T EDUC., http://schools.nyc.gov/Accountability/ resources/assessments/default.htm (last visited Oct. 23, 2016).

137. See Periodic Assessment Options, N.Y.C. DeP'T Educ., http://schools.nyc.gov/ Accountability/resources/assessments/PAOptions.htm (last visited Oct. 23, 2016).

138. See Bill Tucker, Educ. Sector Reports, Putting Data into Practice: Lessons FROM NEw YORK CITY 1-2 (2010), http://www.oxydiane.net/IMG/pdf_Putting_Data_Into_ Practice_RELEASE.pdf.

139. See, e.g., N.Y.C. Dept. of Educ., Children First Intensive Inquiry Team HANDBOOK 3 (2008) [hereinafter INQUIRY TEAM HANDBOOK], http://is239.schoolwires.com/ cms/lib/NY18000436/Centricity/ModuleInstance/590/Inquiry_Team_Handbook.pdf. 
children. ${ }^{140}$

As independent studies using sophisticated methodologies have found, ${ }^{141}$ the Bloomberg-Klein reforms in New York City schools between 2003 and at least 2010 (when most of the studies terminated) were strongly associated with substantially improved student outcomes. High-school graduation rates - which had remained stagnant for decades by the City's own measures at around 50 percent — climbed to 70 percent by $2010 .{ }^{142} \mathrm{New}$ York State later began calculating graduation rates using a more demanding methodology, and it too registered substantial gains in New York City. ${ }^{143}$ The federal government's still stricter calculation (which it reported only between 2002 and 2005) showed still greater gains. ${ }^{144}$ During this period, the graduation rates of black and Latino students increased at twice the rate of white and Asian students. ${ }^{145} \mathrm{~A}$ major cause of the increase was the city's closure of 140 large failing high schools with graduation rates perennially well below 50 percent and their

140. See, e.g., id. at 69-73 (listing data an inquiry team may use); Fullan \& BoyLE, supra note 87 , at 40 (describing inquiry as "analyz[ing] all the performance data available to find gaps in their learning”); Nell Scharf Panero \& JoAn E. TAlbert, Strategic Inquiry: Starting SMALl FOR BIG RESUltS IN EDUCATION 13 (2013) (describing the teams, targets, tasks, and training associated with inquiry teams). On the contribution of inquiry to internal accountability, see, for example, $i d$. at 15 ("[E]stablishing . . . a team that is collectively responsible for improving outcomes for a specific shared group of students in the school engenders shared accountability.").

141. See, e.g., James J. Kemple, Research All. for N.Y.C. Sch., The Condition of New York City High Schools: Examining Trends And LoOKing Toward the Future 3 (2013); WONG \& SHEN, supra note 85, at 46; Hill, Leadership and Governance, supra note 93, at 26 (comprehensively surveying studies); see also ROBERT BALFANZ ET AL., CIVIC ENTERS., BUILDING a Grad Nation: Progress and Challenge in Ending the High School Dropout Epidemic 13 (2014), http://new.everylgraduates.org/wp-content/uploads/2014/04/BGN_2014_Report.pdf (crediting recent increases in high school graduation rate nationally, in part to reforms that "began in New York City [which] replace[d] dropout factories with new, smaller high schools specifically designed for students from high-poverty neighborhoods").

142. N.Y.C. DeP'T of EduC., NYC Graduation Rates Class of 2010 (2006 Cohort) (2011), http://schools.nyc.gov/NR/rdonlyres/678EA9CF-69C0-4CFD-87EF-7E0F670059C2/0/ GRADRATE2010_SHORT_\%20HIGHLIGHTS_WEB.pdf; see JAMES KEMPLE, High SCHOOL Closures in New York City: Impacts on Students' Academic Outcomes, Attendance, AND MOBILITY 49 (2015), http://steinhardt.nyu.edu/scmsAdmin/media/users/sg158/PDFs/hs closures/HighSchoolClosuresinNewYorkCity_ResearchAllianceforNYCSChools_pdf.pdf (crediting the Bloomberg-Klein "set of interlocking systemic reforms that were implemented at an unprecedented pace and scale" with large increases in the graduation and college enrollment rates "[a]fter decades of stagna[tion]").

143. SHAPIRO \& HASSETT, supra note 123 , at 8.

144. See N.Y.C. DeP'T Of Educ., InVESTing In InNOvation Fund SCALE-UP GRANT 33-34 (2010), https://www2.ed.gov/programs/innovation/2010/unfunded/narratives/u396a100063.

145. N.Y.C. DeP'T of Educ., What's NeXt for School Accountability in New York CiTY 8 (2013), http://observgo.uquebec.ca/observgo/fichiers/33202_redditiondecomptes.pdf. 
replacement with new small high schools with above-average graduate rates. $^{146}$

Large gains in rates of students performing at or above "proficiency" levels on state tests also occurred. Although New York City has substantially higher rates of low-income and minority students $(67$ and 69 percent, respectively) than the state at large (43 and 42 percent, respectively) and as of 2003 had proficiency rates 11.9 percent lower than the rest of the state in fourth-grade reading and 11.4 percent in fourthgrade math, by 2010 it had effectively closed the proficiency gap with the rest of the state. ${ }^{147}$ During the same period, the proficiency gap between the rest of the state and its other large cities-Buffalo, Rochester, Syracuse, and Yonkers - stagnated. ${ }^{148}$ A rigorous study designed to isolate test score gains attributable to the Bloomberg-Klein reforms from those predicted by preexisting trends and separate simultaneous initiatives concluded that, between 2002-2003 and 2008-2009, the reforms were associated with, respectively, 17- and 15-percent increases in fourth- and eighth-grade reading scores, and 16- and 20-percent increases in fourth- and eighth-grade math scores, beyond what would have occurred had the reforms not been implemented. ${ }^{149}$ Improvement on

146. Rebecca Unterman, MrdC, Headed to College: The Effects of New York City's Small High Schools of Choice on Postsecondary Enrollment 3-4 (2014), http://www.mdrc.org/sites/default/files/Headed_to_College_PB.pdf (finding that, for school years 2005-2006 through 2008-2009, enrollment as a ninth grader in one of the new small high schools increased average on-time high school graduation rates for all students by 9.4 percentage points, for black males by 12.2 percentage points, and for special education students by 13.4 percentage points; they also increased graduates' rates of enrollment in postsecondary institutions by 8.4 percentage points); Frequently Asked Questions About MRDC's Study of Small Public High Schools in New York City, MDRC, https://www.mdrc.org/publication/frequently-askedquestions-about-mdrc-s-study-small-public-high-schools-new-york-city (last updated October 2014) (noting that New York City's small schools of choice program was designed to replace failing high schools).

147. See James J. Kemple, Children First and Student Outcomes: 2003-2010, in EdUCATION REFORM IN NEW YoRk City, supra note 90, at 255, 270; SHAPIRO \& HASSETT, supra note 123, at 7. In 2010, New York State recalibrated the scores required to establish proficiency, causing significant decreases in proficiency rates statewide. James Liebman \& Jonah E. Rockoff, Moving Mountains in New York City: Joel Klein's Legacy by the Numbers, EDUC. WK. (Nov. 30, 2010), http://www.edweek.org/ew/articles/2010/11/30/14liebman.h30.html. In 2013, New York State increased the rigor of state examinations to coincide with the adoption of the more demanding Common Core State Standards, again causing decreases in statewide proficiency rates. Javier C. Hernandez \& Robert Gebeloff, Test Scores Sink as New York Adopts Tougher Benchmarks, N.Y. Times (Aug. 7, 2013), http://www.nytimes.com/2013/08/08/nyregion/under-new-standardsstudents-see-sharp-decline-in-test-scores.html. In both cases, however, the proficiency declines in New York City were far less pronounced than in the state's other large cities. See SHAPIRO \& HASSETT, supra note 123, at 7; Liebman \& Rockoff, supra.

148. Liebman \& Rockoff, supra note 147.

149. Kemple, supra note 147. 
the federal National Assessment of Educational Progress (NAEP) was patchier but still evident. In the decade after 2003, New York City's average fourth-grade math scores on NAEP increased ten points (226 to 236) compared to an increase of seven points nationally (234 to 241), and nine points (224 to 235) for a subset of large urban school districts for which local results are broken out from state results. The corresponding gains in reading scores were six points (210 to 216) compared to an increase of five points nationally (216 to 221), and eight points (204 to 212) for the urban assessment districts. ${ }^{150}$

\section{c. Collaborative Reform: Baltimore}

The reforms discussed above all seek to motivate educators to improve student outcomes and support them in taking self-conscious steps to learn why instruction that succeeds for some children fails for others and adjust strategies accordingly. Although those reforms differ in the balance they strike between motivation and support and between external and internal accountability, ${ }^{151}$ they mainly fall toward the motivation and externalaccountability ends of the spectrums. In contrast, reforms in Baltimore fell toward the support and internal-accountability poles. ${ }^{152}$

After Martin O'Malley was elected mayor of Baltimore in 1999, he implemented a program known as CitiStat ${ }^{153}$ to use data from everyday experience to improve the delivery of city services. ${ }^{154}$ Every two weeks, O'Malley or a deputy mayor would meet with leaders of each agency, peppering them with questions about their data on and responses to key public problems the agency faced - what available data revealed about levels of success in addressing problems, what better data could be collected, what comparisons of service-delivery outcomes in different

150. TUDA District Profile, NATION's REPORT CARD http://www.nationsreportcard.gov/ reading_math_tuda_2013/\#/tuda-profiles (last visited Nov. 2, 2015).

151. See Childress et al., supra note 92 (distinguishing external and internal accountability).

152. See Allen Grossman et al., Pub. Educ. Leadership Project at Harvard Univ., Baltimore City Public Schools: Implementing Bounded Autonomy 12 (2011).

153. Tina Rosenberg, Armed with Data, Fighting More Than Crime, N.Y. Times (May 2, 2012, 7:00 AM), http://opinionator.blogs.nytimes.com/2012/05/02/armed-with-data-fightingmore-than-crime. CitiStat was inspired by CompStat, a 1990s NYPD program in which " $[p]$ recinct commanders appear before the N.Y.P.D. leadership every few weeks to be questioned about their performance. If the numbers are not good, the commander must explain why-and have a specific plan for improvement. The next meeting begins with questions about how well those commitments were kept." Id.; see ANSELL, supra note 22, at 104-25 (describing early versions of CompStat as a collaborative learning process).

154. Rosenberg, supra note 153 (noting CitiStat's application to issues ranging from potholes to homelessness and domestic violence); see Teresita Perez \& REeCE Rushing, CTR. for Am. Progress, The CitiStat Model: How Data-Driven Government Can Increase EFFICIENCY \& EFFECTIVENESS 6 (2007), http://cdn.americanprogress.org/wp-content/uploads/ issues/2007/04/pdf/citistat_report.pdf. 
parts of the city or different subdivisions of the agency revealed about the problems' causes and solutions, and the agency's plan and timeline for implementing improvement strategies. ${ }^{155}$ Follow-up meetings focused on whether the agency had implemented its plans and met tentative targets, how it was altering its course in the face of uneven success, how the mayor and city leadership could support and enhance the plans, and what agencies facing similar problems (e.g., garbage and snow removal) could learn from one another. ${ }^{156}$ By the end of each meeting day, CitiStat analysts had a list of mutual commitments from the city and agency and information that would be presented at the next meeting. ${ }^{157}$

The mayor who succeeded O'Malley continued this methodology ${ }^{158}$ and prioritized data-driven accountability for Baltimore's school system by hiring New York City's Deputy Schools Chancellor Andres Alonso as the Baltimore districts' CEO in 2007. ${ }^{159}$ Alonso's first step in Baltimore was to grant schools and their principals greater instructional and operational autonomy than they previously had exercised. ${ }^{160} \mathrm{He}$ facilitated the transfer of power from the central district to schools by cutting central staff and implementing a funding formula "that allocated money to schools based on their students' needs."161

In return for empowering schools and their leaders, Alonso held them accountable for the student outcomes their choices generated. ${ }^{162}$ To do so, Alonso's Office of Achievement and Accountability created a twopart School Accountability Framework (SAF) ${ }^{163}$ : a quantitative School Progress Report that analyzed the academic progress made by each school's students and a qualitative School Effectiveness Review (SER)

155. Rosenberg, supra note 153.

156. Id.

157. Id.

158. See Welcome to Mayor's Office of CitiStat, BALT. CiTY, http://citistat.baltimorecity.gov (last visited Apr. 11, 2017).

159. See Sabrina Tavernise, A Mission to Transform Baltimore's Beaten Schools, N.Y. TimES (Dec. 1, 2010), http://www.nytimes.com/2010/12/02/education/02balti.

160. Erica L. Green \& Luke Broadwater, City Schools Chief Alonso Resigns, BaLt. Sun (May 6, 2013), http://articles.baltimoresun.com/2013-05-06/news/bs-md-ci-alonso-resigns20130506_1_tisha-edwards-school-construction-money-school-board.

161. $\bar{I} d$; Lesli A. Maxwell, Andrés A. Alonso, Baltimore Schools CEO, to Resign, Educ. WK. (May 6, 2013), http://blogs.edweek.org/edweek/District_Dossier/2013/05/andres_a alonso_baltimore_scho.html; Tavernise, supra note 159 (describing Alonso's "sweeping reorganization of the [Baltimore] school system, closing [of] failing schools, slashing [of] the central office staff by a third and replacing three-quarters of all school principals" with strong initial results).

162. Interview with Dr. Andres Alonso, Former Superintendent, Balt. Pub. Sch., in New York, N.Y. (Mar. 7, 2014).

163. Sarah Yatsko, Ctr. on Reinventing Pub. Educ., Baltimore and the Portfolio DistRICt STRATEGY 24 (2012), http://files.eric.ed.gov/fulltext/ED532896.pdf. 
performed by trained reviewers. ${ }^{164}$ Described as a "frank professional dialog," 165 the SER resembled a CitiStat meeting. The school's outcomes on its most recent SAF, the underlying data, and strategic and operational documents were provided to the SER team ahead of its visit, with further evidence gathered on-site. ${ }^{166}$ School leadership, staff, students, and families participated in focus groups with the reviewers, and the SER team shared verbal conclusions with the school leader at the end of the visit and before writing a formal report. ${ }^{167}$ Alonso also conducted periodic meetings with the principal of each school, reviewing the school's recent SAF and SER results, enrollment data reflecting its attractiveness to families, strategies for dealing with weak spots the data revealed, evidence of the responsive strategies' effects, and reactions by the school and its leadership to evidence of the strategies' success or failure. ${ }^{168}$ To build educators' capacity to use this information to develop student- and school-specific improvement plans, Alonso established mentoring structures for new teachers and problem-solving networks of teachers and principals across different schools. ${ }^{169}$ Finally, based on comparative outcome and demand data, SER results for all Baltimore schools, and his own intensive observation of each principal's ability and of each school's disposition to improve, Alonso made annual decisions about who should lead schools, which schools should be closed, and which new schools should be created. ${ }^{170}$ Although Alonso's tenure was not without setbacks, ${ }^{171}$ "graduation rates skyrocketed," "test scores saw historic growth," and enrollment and attendance steadily increased. ${ }^{172}$

164. Balt. City Pub. Sch., School Effectiveness Review Protocol: 2011-2012, at 1 (2012), http://www.baltimorecityschools.org/cms/lib/MD01001351/Centricity/Domain/6823/ 20120518-SERprotocol.pdf.

165. Id. at 3.

166. Id. ("Evidence collection begins with a review of all relevant documents provided to the SER team. While on site, evidence collection continues through additional document reviews ....").

167. Id.

168. Interview with Dr. Andres Alonso, supra note 162.

169. Id.

170. Green \& Broadwater, supra note 160.

171. 2 Baltimore City Schools Confirmed to Have Cheated on State Tests, CBS BALT. (June 23, 2011, 11:09 PM), http://baltimore.cbslocal.com/2011/06/23/2-baltimore-city-schoolsconfirmed-to-have-cheated-on-state-test/. After students' wrong answers were erased and replaced at two Baltimore schools, Alonso adopted aggressive security protocols and independent monitoring. Id.; see Lesli A. Maxwell, Atlanta's Cheating Aftermath: What Other Districts Are Doing, Educ. WK.: Dist. Dossier Blog (Apr. 4, 2013, 12:44 PM), http://blogs.edweek.org/ edweek/District_Dossier/2013/04/atlantas_cheating_aftermath_wh.html.

172. Green \& Broadwater, supra note 160. 


\section{d. Federal Policy Under the Obama Administration}

The reform movement also altered national education policy. President Obama entered office eight years into the implementation of the No Child Left Behind Act of 2001 (NCLB). ${ }^{173}$ Although NCLB's conditioning of federal funds on states' creation of standards for and annual assessment of reading and math proficiency ${ }^{174}$ exposed pervasive achievement gaps between middle-class and other schools, ${ }^{175}$ its design harmfully reinforced inflexible constraints on the nations' schools. In particular, the Act set rigid targets for schools and triggers for intervention that penalized schools with substantial numbers of poor and minority students and gave educators little help in identifying and overcoming learning obstacles. ${ }^{176}$

Despairing of congressional action to fix NCLB, the Obama administration used billions of dollars in competitive grants ${ }^{177}$ and waivers from NCLB requirements to motivate and empower states to experiment with more rigorous learning standards, teacher evaluation, and steps to revitalize or close low-performing schools. ${ }^{178}$ Indicating the potential impact of such steps are learning gains in Tennessee and Washington, D.C., two of the earliest and most avid users of the grants and waivers to elevate standards, evaluate and improve teachers, adopt diagnostic school metrics, and restructure chronically failing schools or replace them with charter or other schools. ${ }^{179}$ From 2003 to 2013,

173. See Martin A. Kurzweil, Disciplined Devolution and the New Education Federalism, 103 CALIF. L. Rev. 565, 595 (2015).

174. No Child Left Behind (NCLB) Requirements for Schools, GREATSCHOOLS.ORG, http://www.greatschools.org/definitions/nclb/nclb.html (last visited Feb. 25, 2016).

175. See Kurzweil, supra note 173, at 595.

176. See Raywid, supra note 22, at 183 ("It is not surprising ... that the [NCLB's] sharply tightened controls . . . are now yielding complaints that schools are overregulated and burdened with stultifying homogenization."); Kurzweil, supra note 173, at 597-99.

177. American Recovery and Reinvestment Act of 2009, Pub. L. No. 111-5, 123 Stat. 115; Overview Information; Race to the Top Fund; Notice Inviting Applications for New Awards for Fiscal Year (FY) 2010, 74 Fed. Reg. 221 (Nov. 18, 2009).

178. See Kurzweil, supra note 173 , at 605-08.

179. D.C. Office of the State Superintendent of Educ., Race to the Top: Executive SUMMARY 1 (2015), http://www2.ed.gov/programs/racetothetop/state-reported-sharing/ dcexsumm.pdf; Press Release, U.S. Dep't of Educ., supra note 1; ESEA Flexibility, U.S. DEP'T EDUC., http://www2.ed.gov/policy/elsec/guid/esea-flexibility/index.html (last visited Feb. 25, 2016); see Edward Crowe, Ctr. for Am. Progress, Race to the Top and Teacher Preparation: Analyzing State Strategies for Ensuring Real accountability and Fostering PROGRAM InNOVATION 10-12 (2011), https://www.americanprogress.org/wpcontent/uploads/issues/2011/03/pdf/teacher_preparation.pdf; JAMES S. LIEBMAN ET AL., RAISE Your Hand Tex., Texas InNovation Schools: A Pathway to Success for Autonomous SCHOOLS IN TEXAS 16 (2015), http://www.raiseyourhandtexas.org/wp-content/uploads/ 
Tennessee's mathematics and reading NAEP scores increased twelve and eight points, respectively - well above changes nationwide. ${ }^{180}$ In the year after the implementation of its federally motivated reforms, Tennessee's students experienced their largest single-year achievement gain in history. ${ }^{181}$ D.C. did even better, achieving the largest gain in NAEP scores ever recorded - twenty-four and seventeen points, respectively, in math and reading, compared to gains of seven and four points nationally. ${ }^{182}$ Building on these steps, Congress finally replaced NCLB with the Every Student Succeeds Act of 2015, adopting arrangements even more conducive to state and local flexibility and experimentation. ${ }^{183}$

\section{Two Puzzles}

The above analysis reveals two puzzles. The first is a mismatch between the reforms' seeming success in improving student outcomes and the controversy they have engendered. Although jurisdictions that have implemented comprehensive reforms often exceed the national average in terms of student achievement, ${ }^{184}$ their reforms have encountered serious resistance from both the public at large and the populations the reforms benefit the most. ${ }^{185}$

2015/04/Texas-Innovation-Schools_ResearchReport.pdf (discussing Tennessee's innovative steps to revitalize poor performing schools).

180. NATion's Report CARD, What States ARE MAKing Gains?, http://nationsreportcard.gov/reading_math_2013/\#/state-gains (last visited Nov. 6, 2016); Kevin Willis, Tennessee Has Biggest Improvement in High School Graduation Rate in Nation, WKU PUB. RADIO (Feb. 25, 2013), http://wkyufm.org/post/tennessee-has-biggest-improvement-highschool-graduation-rate-nation.

181. Arne Duncan, The Tennessee Story, Huffington Post (July 23, 2012, 1:00 PM), $\mathrm{http} / / /$ www.huffingtonpost.com/arne-duncan/the-tennessee-story_b_1695467.html.

182. NATION'S Report CARD, supra note 180; see Emma Brown, D.C. High School Graduation Rate Ticks up, but Wide Achievement Gap Remains, WASH. Post (Dec. 20, 2013), https://www.washingtonpost.com/local/education/dc-graduation-rate-ticks-up-but-wide-achievementgaps-remain/2013/12/20/2acc752a-69c5-11e3-a0b9-249bbb34602c story.html. Again, in 2015, D.C. "outpace[ed] the nation in [NAEP] score gains" and "had greater gains than [other] large cities.” Peggy G. Carr, Nat'l Ctr. for Educ. Statistics, Commissioner's Report: 2015 National Assessment of Educational Progress (NAEP) Grades 4 and 8 Mathematics and READING (2015), http://nces.ed.gov/WhatsNew/commissioner/remarks2015/ 10_28_2015.asp.

183. See Jessica Bulman-Pozen, Executive Federalism Comes to America, 102 VA. L. ReV. 953, 987-92 (2016) (describing state flexibility under ESSA to experiment with new ways to motivate and facilitate improved student results subject to federal comparative oversight of states); Every Student Succeeds Act (ESSA), U.S. DeP'T EDUC., http://www.ed.gov/essa (last visited May 20, 2017) (comparing ESSA to Obama administration grant and waiver programs).

184. See, e.g., Natalia E. Pane, Child Trends Hispanic Inst., Math Scores Add up For HISPANIC STUDENTS 3 (2014), http://www.childtrends.org/wp-content/uploads/2014/11/201459MathScoresAddUpReport.pdf (identifying seven U.S. school districts achieving "remarkable" or "notable" score gains for Hispanic fourth and eighth graders, all but one of which (Austin) are "reform" districts: Boston, D.C., Charlotte-Mecklenburg, Chicago, Houston, and Los Angeles).

185. See supra notes 13,20 and accompanying text. 
The second is a gap in the reforms themselves. Sections I.A and I.B above link the problems with the nation's schools to a combination of inward-focused bureaucratic governance and outward-facing specialinterest politics. Yet the reforms seem to have focused only on replacing bureaucracy, leaving intact interest-group politics as the medium through which much of the resistance to the reforms has been transmitted. Before this Article considers whether the latter gap explains the former mismatch, the next Part examines the logic of the governance changes the reforms undertake and their implications for special-interest politics and alternatives.

\section{The InABILITY of PROMINENT Alternatives to BUREAUCRACY to EXPLAIN OR SUSTAIN THE REFORMS}

Bureaucracy's limitations in public education and other sectors have engendered a number of alternative approaches to governance, including three prominent ones considered in this Part: marketization, managerialism, and professionalism/craft. As one would expect of efforts to realign a sector as broad as U.S. public education, the reforms are likely influenced by all three alternatives; this Article concludes, however, that these alternative governance models do not principally drive the reforms, nor does any provide an effective model of civic engagement to replace special-interest politics.

\section{A. Marketization}

Marketization replaces direct action by the government with artificial markets for distributing public goods, such as schools or constraints on pollution. ${ }^{186}$ The goal is to enlist consumer demand and preferences to govern access to services or regulate harms. ${ }^{187} \mathrm{In}$ lieu of centralized, onesize-fits-all solutions that cannot account for diverse conditions or needs, marketization uses the government's distribution of vouchers to allow diverse demands to induce autonomous and decentralized actors to provide an appropriate range of products and services. ${ }^{188}$ By limiting the government to administratively modest tasks, marketization also aims to diminish bureaucratic ills associated with big government and excessive discretion by field staff. ${ }^{189}$

186. Geoff Whitty \& Sally Power, Marketization and Privatization in Mass Education Systems, 93 InT’L J. EDUC. Dev. 94 (2000).

187. See Charles F. Sabel \& William H. Simon, Minimalism and Experimentalism in the Administrative State, 100 GEO. L.J. 53, 57-60 (2011) describing school and housing vouchers and cap-and-trade regimes as common examples).

188. See James S. Liebman, Voice, Not Choice, 101 YALE L.J. 259, 260-61 (1991) (book review).

189. See Sabel \& Simon, supra note 187 , at 57 . 
Marketization strives for less rather than new forms of politics. By substituting private choices for government action, marketization limits the control that aggregated special interests can exert through influence over government officials. Undermining its value, however, this substitution of choice for traditional avenues of voice diminishes democratic control over public goods, while leaving crucial decisions as to the artificially prescribed value, distribution, and constraints on the use of vouchers to officials buffeted by special-interest politics. ${ }^{190}$ Both limitations may explain the failure of many voucher programs to achieve their objectives. ${ }^{191}$

Marketization has influenced two common proposals for altering public education: vouchers and charter schools. ${ }^{192}$ Under a voucher system, parents receive a government-issued certificate they can apply toward tuition at either a private or public school. ${ }^{193}$ Parents bear tuition burdens beyond the voucher amount. A pure marketization system would replace all public schools with a private voucher system - a move with no realistic prospects because most families value public schools, and maintaining full-blown voucher and public education systems is prohibitively expensive. ${ }^{194}$ Although at least seventeen states have authorized the limited use of vouchers by mostly disadvantaged families, ${ }^{195}$ the strategy has not figured prominently in any of the modern reforms discussed above, which aim to improve, not displace, public schools.

In any event, marketization is unlikely to correct the ills of bureaucracy in the education context. Pure marketization, the division of existing subsidies for public schools into roughly equal bits for distribution to all families - as middle-class families would demand in return for giving up public schools - would drastically aggravate the existing stratification of schools by wealth, social capital, and results. ${ }^{196}$

190. See Liebman, supra note 188 , at 313 ; Sabel \& Simon, supra note 187 , at $74-75$.

191. See Liebman, supra note 188, at 282, 284; Sabel \& Simon, supra note 187, at 74-75.

192. Cf. Fullan \& Boyle, supra note 87 , at 37-38 (criticizing New York City reforms as premised on "pure market-based ideology").

193. Becky Vevea, What Is a School Voucher?, GREAT ScHOols, http://www.greatschools.org/gk/articles/school-vouchers/ (last visited Feb. 13, 2017).

194. See Liebman, supra note 188 , at 278, 280-86.

195. Vouchers Don't Work: Evidence from Milwaukee, DiAne Ravitch's Blog (Mar. 29, 2013), http://dianeravitch.net/2013/03/29/vouchers-dont-work-evidence-from-milwaukee.

196. See Raywid, supra note 22, at 197 (noting the "intensifying ethnic and socioeconomic segregation in schools" as "middle class and affluent parents often select open schools ..., while working class parents gravitate toward back-to-basics and fundamental schools"); PAUL T. HILL \& Mary Beth Celio, Fixing Urban Schools 52 (1998) ("Privileged groups would seek to form exclusive enclaves, and school leaders would compete for easy-to-educate and high-prestige clienteles . . . . Working-class families and hard-to-educate groups would be left with school providers who ... could not compete for the more desirable students."). 
This likely explains why most voucher programs limit the option to lowincome households. ${ }^{197}$ Those programs have, at best, a mixed record of improving student outcomes and driving up average school quality. In Milwaukee, for example, private school enrollment has increased, but the financial boon to such schools has "allowed some schools to persist despite ... lackluster academic programs and subpar educational facilities." 198 A recent five-year study found that non-voucher students performed just as well as their voucher student counterparts in many subjects. ${ }^{199}$ Results in Cleveland were even less promising, as voucher students performed less well than their public school peers in math. ${ }^{200}$

Marketization's influence on the new reforms is primarily through charter schools, which receive public monies and are subject to many of the same laws and regulations as traditional public schools but have greater freedom in areas of personnel, curriculum, and scheduling. ${ }^{201}$ From the perspective of families, charter schools are schools of choice, justified on the theory that the competition over students they create will cause traditional public schools to improve in order to maintain their clientele. Unlike schools receiving vouchers, however, charter schools cannot choose their students and instead must accept all those who apply or use lotteries when they are oversubscribed. ${ }^{202}$ Additionally, although charter schools are free of the more stifling aspects of bureaucratic oversight, officials in some states do diligently hold them accountable through rigorous outcome-based standards for issuing, revoking, and

197. See Rajashri Chakabarti \& Joydeep Roy, The Economics of Parental Choice, in ECONOMics of EdUCATION 336, 340 (Dominic J. Brewer \& Patrick J. McEwan eds., 2010) (noting that whether voucher programs resulted in economic stratification largely depended on which families received vouchers and other aspects of programmatic design).

198. See Erin Richards \& Kevin Crowe, Vouchers a Boon for Private Schools in Milwaukee, Racine Counties, MilwaukeE J. Sentinel (May 4, 2013), http://www.jsonline.com/news/ education/vouchers-a-boon-for-private-schools-in-milwaukee-racine-counties-rr9pa61206122011.html.

199. Patrick J. Wolf, The Comprehensive Longitudinal Evaluation of the Milwaukee Parental Choice Program: Summary of Final Reports 12 (2012) http://www.uaedreform.org/downloads/2012/02/report-36-the-comprehensive-longitudinalevaluation-of-the-milwaukee-parental-choice-program.pdf (finding little evidence that participation in the voucher program produced better student outcomes than those of similar students in the Milwaukee Public Schools).

200. Clive R. Belfield, The Evidence on Education Vouchers: An Application to the Cleveland Scholarship and Tutoring Program 17 (Nat'l Ctr. for the Study of Privatization in Educ., Working Paper No. 112, 2006), http://ncspe.tc.columbia.edu/working-papers/OP112.pdf.

201. Facts About Charters, NAT'L Alliance FOR PuB. Charter Schools, http://www.publiccharters.org/get-the-facts/public-charter-schools/faqs/ (last visited Feb. 13, 2017).

202. See, e.g., Developing Admissions and Enrollment Policies for your Charter School, CAL. CHARTER SCH. Ass'N, http://www.ccsa.org/Admissions-and-Enrollment-PracticesKnowledge-Brief.pdf (last visited Feb. 13, 2017). 
refusing to renew their public charters. These states typically are among the minority of jurisdictions where charter schools routinely outperform traditional public schools. ${ }^{203}$

The imperfect freedom of charters to operate and the association between high-performing charter schools and greater levels of government oversight undermine any tight link between marketization as embodied by charter schools and the new reforms and their successes. So do the limited role charters actually play in many reform districts (and the large role they play in many non-reform districts ${ }^{204}$ and the incongruity between marketization and most other aspects of the reforms, including government-imposed standards and assessments and complex public systems of school and teacher evaluation and collaborative inquiry.

\section{B. Managerialism}

Like marketization, managerialism believes that individuals closer to unpredictable conditions on the ground make better decisions than distant central administrators. ${ }^{205}$ Recognizing, however, that it is difficult to use

203. See Elaine Liu, Note, Solving the Puzzle of Charter Schools: A New Framework for Understanding and Improving Charter School Legislation and Performance, 2015 CoLuM. BuS. L. REv. 273, 279, 318-19 (demonstrating a strong correlation between the minority of charter schools nationally that tend to outperform traditional public schools in math and reading and their location in states with legislation subjecting charter schools to careful scrutiny and to withdrawal of their charters based on adverse evidence of their quality and student outcomes); see also CTR. for Research on Educ. Outcomes, Multiple Choice: Charter School Performance in 16 STATES, at 1-8 (2009), http://credo.stanford.edu/reports/MULTIPLE_CHOICE_CREDO.pdf (linking stronger charter school outcomes to state oversight focused on school quality and student outcomes); Nat'l All. for Pub. Charter Sch., Measuring Charter Performance: A Review of Public Charter School Achievement Studies 4 (2010) [hereinafter Measuring Charter PERFORMANCE], http://www.publiccharters.org/wp-content/uploads/2014/01/NAPCS_Achvmnt Stdy_D8.pdf_20110330T165151.pdf (reviewing studies demonstrating greater achievement gains by certain charter schools compared to traditional public schools).

204. The percent of students in charter schools in reform districts such as Baltimore, Boston, Chicago, Denver, Houston, and New York City is below 20 percent, although it is much higher in other reform venues including Cleveland, Newark, New Orleans, and Washington, D.C. Overall, non-reform districts such as Detroit, Flint, Gary, Kansas City, and San Antonio are more consistently represented among high-charter districts than reform districts. See NAT'L ALL. FOR Pub. Charter Sch., A Growing Movement: America's Largest Charter School COMMUNities app. A, at 7-9 (2014), http://www.publiccharters.org/wp-content/uploads/2014/ 12/2014_Enrollment_Share_FINAL.pdf.

205. Raywid, supra note 22, at 158 ("[Managerialism] assumes that today's major problems in education stem from the highly centralized control to which schools have become subject, and the consequent distancing of decision making from the level of application."); Linda Kaboolian, The New Public Management: Challenging Boundaries of the Management vs. Administration Debate, 58 Pub. AdmIN. REv. 189, 190 (1998) ("[Managerialism seeks to] maximize productive and allocative efficiencies that are hampered by ... public agencies unresponsive to the demands of citizens."). 
artificial markets to empower consumers to drive policy decisions, managerialism instead tries to mimic a single feature of markets: the sorting of managers based on how successfully they meet financial or operational targets. ${ }^{206}$ Rather than dissolving public institutions, managerialism limits central administrators' responsibilities to (1) setting simple quantitative outcome targets for local managers who have broad discretion over how to meet them, and (2) rewarding managers who succeed and removing those who fail. ${ }^{207}$

Managerialism also shares marketization's assumption that modern problems and solutions are too complex to identify clearly. Rather than trying to get inside the black box of effective or ineffective actions, managerialism lets results on simple measures do the decisional work. As with marketization, therefore, know-how remains tacit, though managerialism locates it in talented managers' instincts, not in the market's invisible hand. ${ }^{208}$ Also like marketization, managerialism proposes no alternative to special-interest politics and instead tries to reduce the range of centralized decisions that special interests are able to influence. ${ }^{209}$

NCLB evidenced managerialism's influence on school policy on the eve of the reform movement. ${ }^{210}$ The law subjected students and schools to difficult-to-achieve targets ${ }^{211}$ and penalized failure with onerous requirements that led districts to fire principals who failed to meet their marks. ${ }^{212}$ Three problems, among others, undermined NCLB's

206. See Cary Coglianese \& David Lazer, Management-Based Regulation: Prescribing Private Management to Achieve Public Goals, 37 LAW \& SoC'y Rev. 691, 692 (2003).

207. See ANSELL, supra note 22, at 135 (“"[Managerialism] requires that elected officials hold managers responsible for results - and implies that voters will then be able to better hold officials responsible for the outcomes of public programs." (quoting Donald F. Kettl, The Global Revolution in Public Management: Driving Themes, Missing Links, 16 J. Pol'y ANALysis \& MGMT. 446, 456 (1997))); id. at 695, 717 (giving examples of management-based systems in industries other than education).

208. Even if skilled managers know how to replicate their success, managerialism gives them little or no incentive to share their knowledge. See Kaboolian, supra note 205, at 190 (associating managerialism with the view "that public managers are motivated by self-interest and act opportunistically").

209. Gernod Gruening, Origin and Theoretical Basis of New Public Management, 4 INT'L Pub. MGmt. J. 2, 16 (2001) (noting that managerialism tries to separate politics from governance).

210. Qualification for Teachers and Professionals, 20 U.S.C. $§ 6319$ (repealed 2015).

211. See supra notes 174-75 and accompanying text (laying out NCLB goals).

212. For example, school administrators in Atlanta and Norfolk have fired principals who failed to make targets. See Heather Zavadksy, Bringing School Reform to Scale: Five Award-Winning Urban Districts 233 (2009); Rachel Aviv, Wrong Answer, New Yorker (July 21, 2014), http://www.newyorker.com/magazine/2014/07/21/wrong-answer. 
effectiveness. ${ }^{213}$ First, the law measured static proficiency levels, rather than longitudinal improvement, effectively holding schools accountable for how economically advantaged their students were, not for how much students learned. ${ }^{214}$ Second, average proficiency measures incentivized educators to focus on students just above or below the proficiency line and to ignore the many other students so far below or above that status that they were unlikely to affect average proficiency levels. ${ }^{215}$ Third, NCLB's overall target - getting all children in the nation to proficiency by 2014 - turned out to be wildly unrealistic, leaving jurisdictions and educators committed to meeting the targets with two choices: "dummy down" the standards, as many States did, ${ }^{216}$ or cheat, as educators in Atlanta famously did. ${ }^{217}$

The New York City reforms' reliance on systems for rating schools and teachers and imposing consequences also had managerialist connotations. $^{218}$ On closer inspection, however, non-managerialist features dominated, including the use of leading or diagnostic indicators derived from qualitative reviews and student surveys about their schools and teachers, in addition to the lagging, quantitative indicators on which managerialism exclusively relies; disaggregation of both types of information down to the level of individual students, which serves no managerialist function; and inquiry teams' use of all available information to hypothesize and test causes and solutions for instructional failure. ${ }^{219}$ In decidedly non-managerialist fashion, these strategies use tests scores and a variety of qualitative information about schools and educators to facilitate the explicit learning and transfer of knowledge that marketization and managerialism eschew as discredited echoes of bureaucracies' faith in learned experts. ${ }^{220}$ Rather than lining up all school

213. See, e.g., Jim Hull, Measuring Student Growth: A Guide to Informed Decision Making, CTR. FOR PUB. EDUC. (Nov. 9, 2007), http://www.centerforpubliceducation.org/Main$\mathrm{Menu} /$ Policies/Measuring-student-growth-At-a-glance/Measuring-student-growth-A-guide-toinformed-decision-making.html; see also Joel Klein, Lessons of Hope: How to Fix OuR SCHOOLS 255 (2014) (criticizing NCLB's focus on static proficiency rates, not student growth); Ledyard McFadden, New York's Quest for Excellence, EDUC. LEADERSHIP, Oct. 2008, at 62, 63 (similar).

214. See sources cited supra note 213.

215. See Hull, supra note 213.

216. Michele McNeil, Arne Duncan Vows Push on Range of Education Priorities, Educ. WK. (Apr. 22, 2014), http://www.edweek.org/ew/articles/2014/04/23/29secretary.h33.html (quoting Secretary Duncan's claim that nineteen states "dumm[ied] down" standards in response to poor NCLB results).

217. See Aviv, supra note 212.

218. See supra notes $127-32$ and accompanying text.

219. See supra notes $139-40$ and accompanying text.

220. See, e.g., Childress et al., supra note 92, at 12-13; McFadden, supra note 213, at 6264. See generally Jal D. Mehta et al., Schooling as a Knowledge Profession, EDUC. WK. (Mar. 28, 
and classroom managers from best to worst and imposing consequences accordingly, the New York reforms use performance indicators mainly to motivate and facilitate a search for transferrable local expertise and secondarily to identify the few schools and educators so chronically incapable of learning to improve and so harmful to children that they do not belong in the system. ${ }^{221}$

Finally, managerialism's failure to provide an alternative to specialinterest politics and its reliance instead on diminishing the range of issues that bureaucrats control leave targets vulnerable for another reason. As long as central administrators retain the power to set goals and hold principals and teachers accountable for failing to meet them, the likeliest outcome is that the interest groups with the greatest influence over school bureaucracies - those representing the very same principals and teachers - will succeed in disrupting the process. ${ }^{222}$

\section{Professionalism/Craft}

Professionalism relies on highly trained and credentialed field-level professionals to exercise their best judgment and hold each other accountable through shared norms. ${ }^{223}$ True professionalism occurs when shared norms have coalesced into a clear body of academic knowledge and codified behavioral standards, as in medicine and law. When the lore is less susceptible to codification - as with ballet dancing and furniture making, as well as teaching - the guides to behavior are those of a "craft," based more on techniques learned by observing experts and intuitive quality judgments by the "collegium" of practitioners than on academic curricula and written standards. 24

2011), http://www.edweek.org/ew/articles/2011/03/30/26mehta_ep.h30.html (arguing that schools need to transition from bureaucratic structures developed many years ago into modern learning and improvement organizations more suited to the current needs of children and the broader society).

221. See, e.g., KLEIN, supra note 213, at 216-19; Accountability That Improves, supra note 127, at 6; Childress et al., supra note 92, at 13.

222. See Jennifer L. Hochschild, Comments on James S. Liebman and Charles F. Sabel, A Public Laboratory Dewey Barely Imagined, 28 N.Y.U. REv. L. \& Soc. Change 327, 329 (2003) (discussing pressure by teachers' unions and other interest groups to lowball or disrupt enforcement targets); Kaboolian, supra note 205, at 191 (claiming it is impossible "to keep [managerialist reforms] apart from politics," given the likelihood of "negotiation of outcome goals, output measures, and resources").

223. See, e.g., Brian Rowan, Applying Conceptions of Teaching to Organizational Reform, in ELMORE, supra note 22, at 31, 32 ("Advocates of teacher professionalism ... [seek] workplaces that give teachers greater authority and power within the educational system and high levels of professional autonomy.").

224. See Hochschild, supra note 222, at 214. 
Like marketization and managerialism, professionalism and craft aim to maximize the autonomy of street-level actors with access to local information. Instead of external influences such as markets and outcome targets, however, it is the professional's or craft practitioner's instincts and lore about how to pursue general objectives that discipline local action-as when welfare agency social workers pursue the "best interests" of children or police officers "keep the peace" in unruly neighborhoods. ${ }^{225}$ Professionalism and craft assume that the infinite variety of circumstances demanding quick decisions by street-level bureaucrats make it impossible to identify right answers or set behavioral rules or targets. Because every case is unique, outcomes cannot be compared, knowledge remains tacit, and the best central managers can do is give broad decision-making discretion to street-level actors with a "knack" for getting the right answer. ${ }^{226}$ Accountability operates through the approbation or opprobrium of other skillful practitioners, and training occurs through the neophyte's absorption of the knack at the master's elbow. 227

In theory, professionalism and craft offer two palliatives for specialinterest politics. They discourage central administrators from making rules or setting targets, leaving little for interest groups to influence, and they rely on expertise to warrant deference from the public in lieu of interest-group oversight. In practice, however, the associations, guilds, and unions that professionals and craft practitioners form may operate as interest groups that subordinate quality norms to the shared interests of their membership. ${ }^{228}$ To the extent practitioner interest groups freeze out central monitors and competing interest groups via the anti-regulatory and deference logics noted above, the result may be a particularly virulent form of monopolistic interest-group influence.

The late Ted Sizer and the Coalition of Essential Schools brought craft notions into the public education conversation starting in the $1970 \mathrm{~s} .{ }^{229}$ Illustrating their influence are a small set of schools developed by a

225. See, e.g., WiLSON, supra note 54, at 9 (illustrating craft approaches to ordermaintenance policing); Simon, supra note 54, at 16-17 (discussing craft influences on government social workers).

226. See supra note 56 and accompanying text.

227. See James Liebman \& Charles F. Sabel, A Public Laboratory Dewey Barely Imagined: The Emerging Model of School Governance and Legal Reform, 28 N.Y.U. REv. L. \& Soc. CHANGe 183, 214 (2003) (describing craft accountability through communities of practice and training through apprenticeship).

228. See, e.g., infra notes 242-47 and accompanying text.

229. See generally SIZER, supra note 54 (discussing the urgent need for more educator autonomy in public schools); About CES, COALITION OF Essential Schools, http://essentialschools.org/about-ces/ (last visited Mar. 18, 2017) (promoting "powerful processional learning communities focused on student achievement"). 
collegium of teachers in East Harlem in New York City under the guidance of Sizer disciple Deborah Meier. ${ }^{230}$ By the 1990s, the success of those schools in creating a cadre of teachers dedicated to the success of poor and minority students led Anthony Alvarado, superintendent of New York City's nearby District 2, to organize a comparable "learning community" among principals and teachers "that connected ... the classroom, the school and the district." ${ }^{231}$ The result was a committed core of educators and evidence of improvement in the middle-class schools comprising half the district. ${ }^{232}$ After several years, however, Alvarado sensed that improved results did not extend to poor and minority children. ${ }^{233}$ Worrying that "we weren't pushing hard enough on what students were actually learning and whether we were reaching the hardest-to-teach," Alvarado adopted performance standards and assessments to make transparent what previously had been tacit, and they confirmed his fears about the differential success of the craft-driven strategies. ${ }^{234}$ The only way of knowing whether students were actually learning, he concluded, was "by getting agreement on what kids should know and be able to do and starting to assess their learning in some systemic way." 235 Informed by data from the new assessments, educator teams revised curricula and programs previously adopted on craft instinct, generating better results for disadvantaged children and establishing a model for the later reforms on which this Article focuses. ${ }^{236}$

In general, progressive educators and teachers' unions have advocated replacing the new reforms - as well as bureaucratic prescriptions and managerialist targets - with teachers' discretion to choose strategies consistent with their vision of a well-rounded, intellectually and emotionally fulfilling education. ${ }^{237}$ Often these proposals revolve around

230. See Deborah Meier, The Power of Their Ideas 25, 29, 48, 57, 153 (1995); Liebman \& Sabel, supra note 227, at 215-16 (describing Meier's work in New York City).

231. Liebman \& Sabel, supra note 227, at 217, 220-21.

232. Id. at $214,224$.

233. Id. at 239 .

234. Richard F. Elmore \& DeAnNa Burney, Continuous Improvement in COMmunity District \#2, New York City 13 (1998); see Richard F. Elmore \& Deanna Burney, School

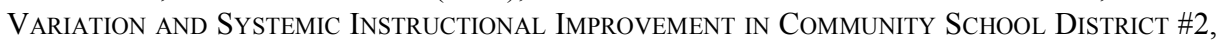
NEW YoRk CiTY 3 (1997).

235. Richard F. Elmore, Investing in Teacher Learning: Staff Development and Instructional Improvement in Community School District \#2, New York City 24 (1997) (quoting Anthony Alvarado).

236. Liebman \& Sabel, supra note 227 , at 224-26 (discussing evidence of improved student outcomes in the second phase of District 2's reforms and those reforms' influence on later initiatives).

237. See, e.g., Samuel A. Culbert, Give Teachers Autonomy, N.Y. Times: Room For Debate (Mar. 28, 2011), http://www.nytimes.com/roomfordebate/2011/03/27/how-to-raise-the-status-ofteachers/give-teachers-autonomy ("The way to make stars out of teachers is to let teachers be 
the unstructured "collaborative communities of practice" that were the hallmark of Meier's East Harlem schools and the first phase of Alvarado's initiatives. In this view, teaching is not "an individual practice"238 but "a reciprocal relationship that spells out mutual obligations" to observe, qualitatively assess, learn, and share experiences with others toward a common goal of improving the teaching craft and student outcomes. ${ }^{239}$

Clearly, the latter proposals resemble features of the new reforms that distinguish them from managerialism, such as qualitative review, inquiry teams, and sympathy for internal accountability. Both assume that students and teachers "are by nature social, interactive learners" and should be freed from rigid bureaucratic rules and inflexible managerialist targets to learn organically from one another. ${ }^{240}$ But as adherents of recent professionalism and craft proposals have argued, increased teacher discretion to respond to the train of unique situations faced is also anathema to what are viewed as stifling problem-solving structures and qualitative rubrics - not to mention externally generated motivational targets, consequences, and comparative data - that are central to the new reforms. In this regard, as with marketization and managerialism, a key disagreement between professionalism/craft and the new reforms is the formers' belief that knowledge is inevitably and preferably tacit, and that efforts to make it explicit - whether by amassing bureaucratic expertise at the center or by promoting structured learning at the peripheryinterferes dangerously with the freedom of discerning families, talented managers, and gifted educators.

Although alluring, professionalism's vision of services intuitively crafted to meet the unique needs of each child ${ }^{241}$ is unlikely to improve teaching and outcomes for disadvantaged children. Left to their own devices, street-level bureaucrats often exercise discretion in two counterproductive ways: (1) lowering expectations to minimize evidence

stars, to let them be as innovative as they can be, to let them find the path that works best for them and their students.").

238. Thomas J. Sergiovanni, Collaborative Cultures \& Communities of Practice, PRINCIPAL LEADERSHIP 49 (2004), http://learningon.theloop.school.nz/moodle/pluginfile.php/ $193291 / \mathrm{mod}$ folder/content/0/Article\%20-\%20Collaborative\%20Cultures\%20and\%20Commun ities $\% 20$ of $\% \overline{2}$ Practice.pdf.

239. Id.

240. See Liebman \& Sabel, supra note 227, at 214, 244 (linking craft and reform views, respectively, to the early and later views of John Dewey).

241. See Diane Ravitch, The Death and Life of the Great American School SYSTEM 169-94 (2010) (describing the author's favorite teacher to illustrate the craft ideal). 
of failure, while dissuading peers who set their sights higher; ${ }^{242}$ and (2) implementing personal or middle-class assumptions and values that do not match the needs of disadvantaged communities. ${ }^{243}$ Both tendencies surfaced in the first phase of Alvarado's District 2 innovations, which benefited middle-class more than other children until combined in the second phase with the performance standards and structured improvement processes that craft resists. ${ }^{244}$ No less worrisome are professionalism's and craft's reliance on the inscrutable, difficult-toscale intuitions of gifted teachers, who in any event are in chronically short supply, and its objection on solidarity grounds to differential pay, leaving gifted teachers to compensate themselves by gravitating to schools with easy-to-manage students. ${ }^{245}$ Finally, the current ability of teachers' unions to serve as the chief proponents of professionalism, ${ }^{246}$ while continuing to hold sway over education bureaucracies through collective-bargaining agreements brimming with limitations on educator discretion, bodes poorly for a craft-oriented solution to the problem of special-interest politics. ${ }^{247}$

\section{Defects Common to the Contending Alternatives}

Although each proposed alternative successfully addresses some of bureaucracy's failures, none satisfactorily explains the ongoing education reforms. Those reforms have not sought the full-scale dismantling of public education that pure marketization requires. Their engagement of administrators and educators in structured, self-conscious inquiry into the processes that lead to better student outcomes contrasts sharply with managerialism's and craft's key assumption that optimal solutions cannot be made transparent, and their use of hard quantitative measures of

242. See Rowan, supra note 223, at 45 (discussing research suggesting that craft approaches can generate "social controls on workers that define a fair day's work," "discourage initiative," and lead teachers acting collectively to lower standards).

243. For discussions of how professionalism generated demands by disadvantaged communities for protections against arbitrary and biased actions by government social workers and police officers, triggering the due process revolution of the late 1960s and 1970s, see WILSON, supra note 54, at 274-77; Simon, supra note 54, at 22.

244. See generally ANTHONy S. BRyK et AL., Organizing SchOOls FOR IMProvement: LESSONS FROM CHICAGO 57 (2010) (finding that schools that improved via professionalism tended to have a preexisting capacity and willingness to improve).

245. See supra notes 68-71 and accompanying text.

246. See, e.g., Nina Bascia, Teacher Unions and Teacher Professionalism in the U.S.: Reconsidering a Familiar Dichotomy, in INTERNATIONAL HANDBOOK OF TEACHERS AND TEACHING: PART ONE 437, 441 (Bruce J. Biddle et al. eds., 1997).

247. See, e.g., Diane Ravitch, Why Teacher Unions Are Good for Teachers-and the Public, AM. EDUCATOR (Winter 2006-07), https://www.aft.org/newspubs/periodicals/ae/winter0607/ ravitch.cfm (offering a craft-inflected argument for union-sponsored limits on educator discretion to protect "teachers' rights" against "arbitrary and unwise" decisions by principals). 
student success to motivate and fuel that inquiry offends craft's resistance to constraints on educator intuition and artistry.

Nor, as we have seen, do any of the alternatives provide a viable model for systematically improving educational outcomes. To be sure, each alternative alters power relations within public institutions by dissolving them entirely or shifting decision-making from the center to one or another category of street-level actors. And each draws on new competencies or expertise - setting the parameters for artificial markets, establishing targets, or exercising local discretion to resolve myriad unique problems. But when it comes to improving how children explicitly and self-consciously learn, all three alternatives - oddly, given the context - assume that overt and self-conscious learning by adults and their institutions is impossible, and that administrative and instructional know-how must remain tacit and mysterious.

The three models likewise offer no alternative to special-interest politics as the primary form of public accountability and civic engagement. ${ }^{248}$ Each attempts to address the pernicious influence of special interests on large-scale bureaucracies by changing how much politics (and government) we should permit or where politics should reside within policymaking structures, but none tries to change how politics, at whatever level, are conducted. Each thus assumes that pluralist politics are natural, immutable, and inevitable and accepts pluralism's distancing of people from the day-to-day operation of their institutions via the separation of politics from governance: Advocacy by the people precedes decision-making by elected officials, which in turn precedes implementation by administrators doubly distant from the public. ${ }^{249}$

Further, marketization, managerialism, and professionalism/craft suppress civic engagement by reducing the ability of the public to influence decision-makers. There are serious costs to treating less democracy-i.e., fewer opportunities for individuals to participate together in self-governance-as the solution to distortions of the democratic process. Stakeholders in any public regime, but particularly those like students, parents, and teachers with a strong stake in effective education, have vast amounts of information that is crucial to the success of the enterprise and yet not easily absorbed by decentralized markets, instinctive managers, or intuitive teachers. This is particularly true of the information held by the critical subset of parents with the least market power, political savvy, and interaction with schools, whose children often struggle the most. No less importantly, even parents with market and political power crave close involvement in their own child's day-to-day

248. See ANSELL, supra note 22, at 17 (“Organizational transformation of public agencies cannot easily occur without a fundamental change in the relationship between agencies and democratic publics.").

249. See id. at $136-37$. 
instruction and in the ongoing governance of their child's school, which likewise is not satisfied by an initial ability to choose the school or by the knowledge that it is managed by a talented principal and staffed by gifted teachers. These parents will demand outlets for that independent interest in democratic participation and, when no other outlets are available, will default to interest-group politics dominated by organized groups whose interests only partly overlap with students'. ${ }^{250}$

In the next two Parts, this Article considers whether there is an alternative to bureaucracy that firmly grounds the new education reforms and offers a concomitant reformation of special-interest politics.

\section{DEMOCRATIC EXPERIMENTALISM AS AN ANTIDOTE TO BUREAUCRACY AND SPECIAL-INTEREST POLITICS}

The remainder of this Article argues that a different governance model - democratic experimentalism (DE) — offers a firmer foundation for ongoing public education reforms and replaces special-interest politics with deeper stakeholder engagement and public accountability. This Part explores the model both in theory and in practice in areas other than U.S. public education. The next Parts explore the extent to which the new education reforms do and do not-and how they could more effectively — track this model's governance and political innovations.

\section{A. Promise, in Theory}

In contrast to bureaucracy's reliance on fixed organizational designs, roles, and goals, DE employs flexible governance structures supporting iterative improvement processes that respond to problems and variable circumstances as they arise. ${ }^{251} \mathrm{In}$ contrast to the belief shared by marketization, managerialism, and craft that know-how and mechanisms for its production are inevitably tacit and intuitive, DE's flexible structures for collecting and processing information to diagnose the cause of problems, develop and test solutions, and measure success strive to make learning ever more transparent and transferable. Successful reforms are "characterized by a process of mutual adaptation" through which "project goals and methods [a]re modified to suit the needs and interests of the local staff and in which that staff change[s] to meet the requirements of the project." 252 Adaptation in response to progressively

250. See, e.g., infra notes $381-85$ and accompanying text.

251. Pincus, supra note 33, at 60 ("If goals are in some sense undefinable, it is inappropriate to adopt the standard rationalist approach of [centrally] defining goals, then seeking means appropriate to achieve them efficiently. . . . [I]t may be wiser to try out systematic innovations and assess their consequences....").

252. Milbrey McLaughlin, Implementation as Mutual Adaptation: Change in Classroom Organization, in Social Program ImPlementation, supra note 33, at 167, 169. 
better understood or evolving conditions is the goal of the process, not evidence that prior practice failed. ${ }^{253}$

Additionally, unlike other alternatives to bureaucracy, DE does not simply change the amount or locus of politics but replaces special-interest politics with mechanisms for previously disenfranchised and disgruntled stakeholders to participate productively and sustainably in shaping and implementing policy.

\section{Governance}

DE combines local units and central staff into a self-sustaining learning process. Local units include government employees and adjacent stakeholders who together possess insight into the circumstances surrounding a problem and its implications for the organization and its public. The central unit sets broad goals and compiles and analyzes data created by local units to inform local processes. By incorporating local agents and stakeholders, DE responds to the diversity of conditions that bureaucracy's fixed solutions often ignore. ${ }^{254}$ Stakeholder participation in making and implementing decisions, and the center's comparative benchmarking of solutions that different local units adopt, steer local action toward legitimate goals and workable solutions in ways that bureaucracy, managerialism, and professionalism/craft cannot. ${ }^{255}$

DE practitioners continuously react to new data, adjusting or abandoning ineffective practices. Stylized, when a local unit encounters an unwanted deviation from the expected (a "problem"), it asks a team of stakeholders to address it, laying aside conflicting values and interests, focusing only on team members' shared stake in a solution, and measuring success based on how substantially the problem recedes. ${ }^{256}$ Depending upon how frequently similar problems arise, the center may periodically review a sample of solutions; deploy facilitators to support local problem-solving and informally spread learning to other sites; or (among many other permutations) identify a recurring problem and ask each unit to develop a locally customized plan to address it, which the center may share with others, often comparing all plans' terms and

253. Id. at 178-80 ("[A]daptation, rather than standardization, is a more realistic and fruitful objective for policymakers and practitioners hoping to bring about significant change in local educational practice ... [and] not an undesirable aberration.").

254. See Joshua Cohen \& Charles F. Sabel, Directly-Deliberative Polyarchy, 3 EuR. L.J. 313, 331 (1997) ("The complexity of problems and solutions - where problems are substantially the product of multiple causes and connected with other problems, crossing conventional policy domains and processes - implies that the appropriate strategy requires coordination across those domains.").

255. See id. at 331-32.

256. Id. at 331 . 
effects. ${ }^{257}$ Team members develop initial hypotheses about the problem's cause and solution; specify success criteria; test the solution; and reassess the surrounding facts, causal theories, solutions, and success measures as evidence accumulates - repeating the process as needed. ${ }^{258}$

DE expects stakeholders to develop, learn, and in that way amass and document explicit knowledge over the course of addressing a problem; provides them with structured opportunities to do so; and confers recognition, including promotion, based on their problem-solving skills. ${ }^{259}$ This "adult learning" also may expose previously hidden obstacles, possibilities, combinations, and variations that help solve a problem while leading participants to develop new interests and values. ${ }^{260}$ This shared process of discovery may in turn reduce conflict among stakeholders and between them and the agency. ${ }^{261}$

Unlike in bureaucracies, the central unit does not supervise day-today administration. Rather, it sets general directions and goals for local deliberation; provides incentives, default structures, and facilitation for local planning and problem-solving; establishes measurements and collects data to compare the progress of local units; uses outcomes and the plans and strategies that achieved them to benchmark acceptable future progress and guide the transfer of models and expertise from one site to the next; and supports the adoption and customization of successful models by less successful units. ${ }^{262}$ Instead of enforcing compliance with uniform procedures, the center provides "the infrastructure and services that support frontline" planning, problem-solving, and innovation. ${ }^{263}$ Central action thus is a "means to create innovation (by building in

257. Id. at 331-32.

258. David P. Weikart \& Barnard A. Banet, Planned Variation from the Perspective of a Model Sponsor, in Social Program IMPLEMENTATION, supra note 33, at 125, 145 ("Educational programs must be a synthesis of theory and practice and must continually be reshaped by developers and participants alike if they are to remain effective."); see also Sabel \& Simon, supra note 187 , at 78 (noting that experimentalist institutions aim "to achieve local adaptation and aggregate learning by combining discretion with duties to report and explain, and by pooling information").

259. See infra notes $288-89$ and accompanying text (illustrating the process described in text with examples from Toyota's practices).

260. See Liebman \& Sabel, supra note 227, at 302-03.

261. Cf. James S. Liebman, Desegregating Politics: “All-Out” School Desegregation Explained, 90 Colum. L. Rev. 1463, 1634 (1990).

262. See, e.g., Sabel \& Simon, supra note 25, at 1029, 1032 (discussing an experimentalist approach some courts have used to improve the quality of services provided in mental health institutions). "The decrees emphasize broad goals and leave the defendants substantial latitude to determine how to achieve them; mandate precise measurement and reporting with respect to achievement; and institutionalize ongoing mechanisms of reassessment, discipline, and participation." Id. at 1032.

263. Sabel \& Simon, supra note 187 , at 90. 
mechanisms that stimulate creativity and diversity), to maintain flexibility, and to correct itself." 264 Authority and influence ebb and flow between local and central units and among local units in reaction to "external changes, new priorities, or internal imbalances." "265

In these ways, experimentalism links central and local units to maximize the problem-solving capabilities of each. While local units adapt solutions to their particular conditions, the central unit manages links between them that alert each to the other's innovations and develops common metrics for comparing local results and ensuring that each site serves all members of its population. ${ }^{266}$ Together, local and central experimentalist units produce solutions that are expertly crafted, locally tailored, and consistent with public ideals.

\section{Politics}

$\mathrm{DE}$ also offers an alternative to the special-interest politics that plague public education and other bureaucratic structures. As with managerialism and professionalism/craft, DE moves many important decisions from the central to the local level, deterring special interests from dominating decisions. Unlike those models, however, DE does not limit the range of issues subject to political control-freezing out important stakeholders with information on how best to implement and improve policy. Rather, DE treats local collaborative problem-solving as a way for informed stakeholders - especially consumers of public services - to share decision-making authority with the local unit of government and share responsibility with the central unit for holding field-level actors accountable. ${ }^{267}$

Second, DE extends democratic control to a much broader range of important decision points than special-interest regimes. The latter focus political activity primarily on policy initiation through elections and the bargaining over of legislation and administrative rules and plans. ${ }^{268}$ Policy implementation is treated as a matter for ministerial followthrough under bureaucratic supervision. ${ }^{269}$ Today, however, uncertainty surrounding problems and unpredictable interactions between solutions and local environments require constant adjustment during implementation that often is more decisive of results than policy as

264. Jane L. David, Restructuring in Progress: Lessons from Pioneering Districts, in ELMORE, supra note 22, at 209, 228.

265. Id.

266. See Cohen \& Sabel, supra note 254 , at 326.

267. Id.

268. See ANSELL, supra note 22 , at 3.

269. See id. 
initially conceived. ${ }^{270}$ Additionally, because bureaucracies struggle to keep field staff from using their control over implementation to advance their own interests, pluralist regimes exert little supervisory, or democratic, control over this most crucial stage of the process. ${ }^{271}$ This is particularly so when, as in public education, groups representing field staff are the most powerful special interests. DE, by contrast, recognizes that policy is made at both the design and implementation phases and subjects both to democratic accountability. ${ }^{272}$ Initial policymaking - the setting of the general direction for local experimentation-occurs at the central level under traditional democratic constraints. ${ }^{273}$ Next, highly participatory and deliberative stakeholder groups initiate local policy by identifying a solution hypothesis, then use the close observation of the policy's implementation as a basis for adjusting the solution-all under central benchmarking oversight. ${ }^{274}$

Finally, DE rejects the premise of pluralist politics that individual interests and values are fixed and that politics is simply the measure of their relative power. ${ }^{275}$ Under DE, the "discipline of the problem" creates an ethical situation in which participants reconsider and modify their interests and values - they learn-in the process of cooperating with others to solve a mutually defined problem and measure success by how well they do so. ${ }^{276}$ Participants discover that their predilections and proposals have much to contribute to the solution but cannot entirely comprise it - and that an effective combination of strategies requires contextualization and refinement of previously fixed desires and principles. A similar process occurs as DE reevaluates policies by benchmarking local solutions against each other. DE's implementation focus has the same effect. Under old politics, political participation and deliberation typically take place in the abstract, generating a single preimplementation decision to allocate inputs in service of contending interests or values. In contrast, under DE, participation and deliberation occur amid ongoing implementation, as a succession of unanticipated conditions put the initial solution to the test, prompting adjustment and further testing. DE's refusal to regard any initial policy as final

270. See Sabel \& Simon, supra note 187, at 56. ("In the realm of uncertainty, policy aims cannot be extensively defined in advance of implementation; they have to be discovered in the course of problem solving.").

271. See supra notes 53-58 and accompanying text.

272. See ANSELL, supra note 22, at 131-34.

273. See id.

274. See id. at 172-74.

275. John Dewey, The Public \& Its Problems 203 (1927) (“[V]iews generated [in response to individuals'] special situations [can] be frozen into absolute standards and masquerade as eternal truths.").

276. See Liebman, supra note 261, at 1608-09 (discussing ethical situations). 
encourages continual reexamination in light of lived experience, diminishing the influence of initially stronger or more outspoken views.

\section{B. Concerns, in Theory}

Although DE avoids many of the defects of bureaucracy and alternative governance models, it has risks of its own. First, the access DE gives to previously disenfranchised constituents comes with deliberative-problem-solving responsibilities that may outstrip constituents' capacity in settings that put a premium on time commitment, education, communication skills, organizational expertise, access to experts, and knowledge of how to identify possible causes and solutions. Imagine, for example, a collaborative effort to use student test scores to improve teachers' instruction. Even many teachers lack the technical expertise needed to understand what test scores can and cannot tell them about how to improve instruction, very few parents have that knowledge, and still fewer teachers and parents know how to "produce evidence-based tailored instruction plans responsive to individual [needs]." ${ }^{277}$ The problem-solving process might include steps to improve participants' capacity, but if there is a threshold below which meaningful participation is unlikely, individuals lacking resources could end up even less enfranchised than they are under traditional politics, where they at least have formal access to voting and interest-group representation. ${ }^{278}$ Relying on the center to provide the necessary resources when the result may be reforms that weaken the center's authority may create conflicts of interest that diminish the quality of its support or the authenticity of decisions reached.

Second, the reach of the participatory rights DE assumes is unclear. Basing those rights on stakeholders' close identification with distinct concerns may simply recreate interest-group politics, invite free riding, or generate "solutions" with harmful externalities for people not at the table. ${ }^{279}$ On the other hand, extending participation rights more broadly might frustrate networks' ability to produce "rational or optimal results"

277. Martha Minow, School Reform Outside of Laboratory Conditions, 28 N.Y.U. REV. L. \& Soc. CHANGe 333, 336 (2003) ("[M]ost teachers lack the knowledge and understanding to perform the new role [experimentalism] imagine[s] for them ... [and few parents and community advocates know how] to assess, monitor, and improve [schools].").

278. See David A. Super, Laboratories of Destitution: Democratic Experimentalism and the Failure of Antipoverty Law, 157 U. PA. L. REV. 541, 561-62 (2008) (claiming that experimentalist public participation is too costly for all but well-funded organizations).

279. Helen Hershkoff \& Benedict Kingsbury, Crisis, Community and Courts in Network Governance: A Response to Liebman and Sabel's Approach to Reform of Public Education, 28 N.Y.U. Rev. L. \& Soc. ChANGE 319, 321-22 (2003) (predicting that allowing any group to participate may "encourage[] secession from groups in order to form fractionated entities that receive the instant privileges of participation"). 
by motivating too much deliberation and too little action. ${ }^{280}$ Moving in the opposite direction and limiting participatory rights could make networks "more exclusive and less transparent than the public/private hybrids that characterize so much of local decision-making." 281 Finding the right balance among these options could prove difficult.

Additionally, examples of successful public experimentation and problem-solving may be too few and too preliminary to convince a critical mass of individuals to embrace the new politics. In Professor Mark Tushnet's view, evidence that experimentalist interactions are "more possible than. . . in the past" 282 is more a consequence of marketization and managerialism (weakening bureaucracies and creating flexible structures and sophisticated accountability systems) and professionalism (generating shared-learning opportunities) than of experimentalism. Thus, whether or not experimentalism is persuasive in theory, Tushnet doubts it will find traction among actors seeking tangible results. ${ }^{283}$

Finally, experimentalist governance entails constant reevaluation and midstream correction. The public could easily perceive this focus on transparent results and continuous improvement as instability and admissions of failure, rather than as the fruitful transformation of evidence of imperfect outcomes into an opportunity for growth and improvement. ${ }^{284}$

To answer these concerns, the next Section offers examples of DE's actual operation outside the area of U.S. public education that counter these objections. The following Part extends the analysis to U.S. public education.

280. Id. at 323 ("[T] 00 much talk can produce inaction; individual speakers may impose a heckler's veto over even the best practices.").

281. Id. at 322 .

282. Mark Tushnet, A New Constitutionalism for Liberals?, 28 N.Y.U. Rev. L. \& Soc. Change 357, 358 (2003).

283. Id. at 360 ("Experimental constitutionalism will get traction when an appropriate political coalition sees how its members' interests will be advanced by the widespread acceptance of experimentalist constitutionalism ....”).

284. See, e.g., Clara Hemphill \& Kim Nauer, Ctr. for N.Y.C. Affairs, Managing By the Numbers: Empowerment And ACCOUnTABility in NeW York City's Schools 55 (2010), https://static1.squarespace.com/static/53ee4f0be4b015b9c3690d84/t/5410b0bee4b04642ac686a d8/1410379966798/ManagingByTheNumbers_EmpowermentandAccountabilityinNYCSchools. pdf (quoting a NYC school principal who agreed that iterative changes made schools "better off than they were" but experienced "trepidation" when asking "how many iterations of change" a system could "endure"). 


\section{Promise, in Practice}

Several examples demonstrate DE's potential to solve entrenched problems without capitulating to special interests. Each example combines stakeholder participation in problem-solving with an iterative, data-driven process, and each addresses concerns discussed above. The examples are roughly arranged based on the size, scope, and identifiability of the relevant stakeholder populations - a factor that may make public education a particularly challenging context for DE.

\section{Toyota}

Toyota's innovative approach to improving its production process is an important early example of DE in action. With its commitment to "continuous improvement"285 - designing work "so problems are evident when and where they occur" and persistently looking for "better ways to do work"286 - Toyota out-competed American car manufacturers despite lacking resources previously thought to be necessary. ${ }^{287}$ Among other steps, Toyota famously trained assembly-line workers to identify flaws at their own or the nearest upstream step in the production sequence; halt the production line immediately to allow rapid corrections to be made; and use a version of structured "inquiry"- "continual, disciplined, accelerated discovery" of causes and solutions - to make necessary corrections themselves before the problem corrupted the entire assembly process. ${ }^{288}$ By empowering line workers as central stakeholders in the company's success and key participants in its collaborative problemsolving processes, Toyota revolutionized not only the internal operations of automobile makers but also the concept of industrial democracy, replacing adversarial interest-group bargaining with experimentalist problem-solving politics. ${ }^{289}$

285. Quality, ТоуотA, http://www.toyota.com/quality (last visited May 27, 2015) ("[S]triving for continuous improvement ... [is] a philosophy that we stand by."); see MiKE Rother, Toyota Kata: Managing People for Improvement, Adaptiveness, and SuPerior RESULTS 5-7 (2010).

286. Steven J. Spear, The High Velocity Edge: How Market Leaders Leverage Operational EXCELlenCE TO BEAT THE COMPETITION 159, 162 (2009).

287. Yuri Kageyama, Toyota World's Top Selling Car Maker for 2nd Year, Associated PRESS: BIG STORY (Jan. 23, 2014), http://bigstory.ap.org/article/toyota-worlds-top-selling-carmaker-2nd-year.

288. See SPEAR, supra note 286, at 158; Quality, supra note 285 ("Every team member has the authority and the responsibility to stop the line if a component or assembly doesn't meet our quality standards."); supra notes 92, 139-40 and accompanying text (discussing structured inquiry).

289. See, e.g., Mark Barenberg, Democracy and Domination in the Law of Workplace Cooperation: From Bureaucratic to Flexible Production, 94 CoLuM. L. REv. 753, 881-82 (1994); A Tribute to Al Shanker, 16 Pew F. ON Educ. Reform 33, 33-34 (1997) (reprinting views 
Toyota shows a way forward for DE in practice, given its success transforming blue-collar workers, whom most companies had relegated to rote rule following, into flexible and effective problem-solvers. The company's extension of its problem-solving "publics" to include suppliers and even customers (whose demand and feedback drive its "lean production" system) provides additional bases for optimism about DE. ${ }^{290}$

In other ways, however, Toyota arguably presents a more favorable environment for engaging stakeholders in problem-solving politics than do public school systems. Participation by employee-stakeholders is mandatory and well-compensated, and participation by suppliers is incentivized by Toyota's market power; collective engagement in problem-solving is part of participants' job description or contractual obligation. In these ways, Toyota does not invite seamless analogy to urban school districts seeking to engage not only thousands of teachers and hundreds of suppliers of curricula, professional development, and after-school programs, but also tens of thousands of families whose dispersion, disconnection from schools, and lack of problem-solving capacity are often the central problem to be solved. Still, the Toyota example shows how field staff previously thought to lack problemsolving and decision-making capacity and commitment to the organization can effectively learn to make and change company practices and policies for the better.

\section{Drug Courts}

Drug treatment courts illustrate how DE can be successfully implemented in public-sector contexts. These courts are an alternative to the traditional criminal justice system and have reduced recidivism by drug-addicted offenders convicted of low-level, non-violent crimes. ${ }^{291}$ Drug courts use an iterative, data-oriented process to engage an array of stakeholders in decision-making and results monitoring. ${ }^{292}$ Individuals charged with drug-related offenses accept responsibility for charged crimes in exchange for enrollment in court-supervised drug-treatment programs and exemption from criminal penalties if they successfully

expressed by famed union leader Albert Shanker on lessons the Toyota model offers to teachers' unions).

290. See SPEAR, supra note 286, at 39-41 (describing incorporation of suppliers and role of customer demand in Toyota system).

291. See U.S. Gov’t Accountability Office, GAO-12-53, Adult Drug Courts: Studies Show Courts Reduce Recidivism, but DOJ Could Enhance Future Performance Measure REVISION EFFORTS 8 (2011).

292. See Michael C. Dorf \& Charles F. Sabel, Drug Treatment Courts and Emergent Experimentalist Government, 53 VAND. L. REV. 831, 832 (2000). 
complete the program. ${ }^{293}$ Actors with a stake in an individual's successthe judge, prosecutor, defense attorney, family members, drug treatment personnel, and the offender herself-jointly construct a treatment plan and monitor relapse events and responsive behaviors for evidence of triggers and effective ameliorative strategies. ${ }^{294}$ In return for federal funding, treatment courts report effective practices to the Department of Justice, which identifies funded courts' future goals based on what is known to be possible. ${ }^{295}$ Drug courts track which treatment programs succeed and fail, funneling offenders away from ineffective programs and gradually improving treatment options for drug users. ${ }^{296}$ Together, these practices subject drug-related crime to a process of "[d]irectly deliberative problem solving," incorporating the outcomes of many experiments into an ever-improving solution set. ${ }^{297}$

Drug courts allay additional concerns about DE's applicability. Large numbers of often poorly motivated, low-capacity participants suffering from a dizzying array of troubles develop problem-solving skills - as do judges, lawyers, and treatment professionals - through involvement in the experimentalist project, without requiring Toyota's intensive, preparticipation training. Additionally, the progression of many dispersed and unconnected participants does not result in a loss of institutional knowledge, because the courts, treatment teams and programs, and the federal government track best practices and feed information back to "local units." Nonetheless, as in the Toyota example, there are incentives for the actors to participate - judges, lawyers, and treatment providers because that is their job; clients and their families given the criminal justice system's vast coercive power - that are not available to public school systems.

\section{Environmental Protection}

In the environmental context, DE brings together disparate actors seeking a "productive yet acceptably sustainable" balance of resource use and environmental protection. ${ }^{298}$ Recognizing the impossibility of achieving the right balance solely through centralized management or regulation, reformers fuse "the broad experience of professional practitioners [with] the contextual intelligence that only citizens

293. Id.

294. See id. at 833-34, 844-46.

295. See id. at $844-45$.

296. See id. at 839. But cf. id. at 865-67 (noting weaknesses in structured monitoring of treatment centers).

297. See id. at 878.

298. Charles Sabel et al., Beyond Backyard Environmentalism, in Boston Review 3, 6 (Joshua Cohen \& Joel Rogers eds., 2000). 
possess." 299 The resulting process is an "exchange between local units," often engaging with private actors and "higher level authorities" within, for example, state environmental-protection departments, the EPA, and the Fish and Wildlife Service. ${ }^{300}$

At the outset, central regulators set broad environmental goals such as declines in the release of toxic chemicals, incidence of unsafe conditions at nuclear power plants, pollution in specified watersheds, or encroachments on habitats. ${ }^{301}$ Central actors then measure progress toward those goals by actors at the factory, habitat, or other local level, while giving those actors the autonomy to decide for themselves in the first instance how much harm reduction is reasonable under their circumstances and how to reach that target through use reduction, conservation, or other similar plans they are required to create. ${ }^{302}$ In return for increased autonomy, local actors report their "performance, plans, and metrics" to the central authority: "how they are doing, how they plan to improve, and what standards they use to assess performance." ${ }^{303}$ Based on strong results achieved under identifiable circumstances, the central authority sets and informs local actors of new standards of performance (more specific than before but with leeway remaining) and generally accepted methods of practice and assessment. ${ }^{304}$ Local units continue working toward the centrally identified goals using broadly defined acceptable performance methods and reporting results, creating feedback loops that replace an assumption of "central, panoramic knowledge" with constant updating based on local experiences. $^{305}$

These regimes encourage broadly disparate actors with an interest in the outcome to participate in generating, implementing, and monitoring plans and targets. Firms may participate because of regulatory mandates or market incentives affected by access to resources the plans address. Government agencies, environmentalists, farmers, first peoples, and recreational users of affected areas have their own concerns about how the same resources are conserved and deployed. ${ }^{306}$ Although cooperation between such groups is initially unlikely, there is evidence that shared interest in the outcome and worries about decisions being left to

299. Id.

300. Id. at 6-7.

301. Id. at 5-7.

302. $I d$. at 7-8 (describing monitoring regime penalizing failures to plan and report).

303. Charles Sabel et al., Beyond Backyard Environmentalism, Bos. Rev. F. (Oct. 1, 1999), $\mathrm{http} / / /$ bostonreview.net/forum/charles-sabel-archon-fung-bradley-karkkainen-beyond-backyardenvironmentalism.

304. Id.

305. Id.

306. Sabel et al., supra note 298 , at 5-7. 
regulatory or judicial fiat can induce willing and effective collaboration. ${ }^{307}$

\section{Chicago Community Policing}

The preceding three case studies (to a diminishing degree) involve limited categories of stakeholders with strong incentives to participate in the experimentalist regime. As DE projects expand to encompass a broader population of individuals and a broader array of motivations, ensuring meaningful participation of affected groups becomes more challenging.

Steps in Chicago to incorporate community input into policing reveal DE's potential for implementation across larger and more dispersed populations. In 1993, the Chicago Police initiated the Chicago Alternative Policing Strategy (CAPS), a prominent feature of which was regular "Beat Community Meetings," in which neighborhood residents met with locally based police officers to identify chronic crime problems facing the neighborhood and attempt to alleviate them through joint problem-solving. ${ }^{308}$ From November 1996 to August 1997, Professor Archon Fung observed the dynamics of the monthly meetings in Traxton, a neighborhood characterized by a division between the predominantly white and middle-class West Traxton and the predominantly black and poor East Traxton. ${ }^{309}$ Before the introduction of the beat meetings, West Traxton inhabitants did their best to preserve the nature of Traxton as two distinct communities separated by physical barriers designed "to keep out what they perceive[d] to be the chaos and crime of the surrounding urban environment." 310

Fung bifurcates the Traxton beat meetings he observed into a first period of "laissez faire" meetings and a second phase of "structured deliberation" meetings. ${ }^{311}$ During the earlier period, the civilian meeting leader allowed participants to determine the direction of the discussion ad hoc. ${ }^{312}$ Through "coordinated and persistent efforts," the relatively privileged West Traxton residents dominated the conversation, raising and demanding answers on questions of comparative insignificancetraffic violations, unlicensed street vendors, loitering. ${ }^{313}$ East Traxton

307. See Bradley C. Karkkainen, Information-Forcing Environmental Regulation, 33 FLA. St. U. L. REV. 861, 878-79 (2006).

308. What Is CAPS?, CHI. POLICE, http://home.chicagopolice.org/get-involved-withcaps/how-caps-works/what-is-caps (last visited May 20, 2017).

309. FUNG, supra note 35, at 174-76.

310. Id.

311. See id. at 179-95.

312. See id. at $185-87$.

313. Id. at $182-83$. 
residents, less practiced in similar assemblages, waited until the end of meetings to voice their often more serious concerns-shootings, unsolved murders, overbearing police conduct - but rarely challenged police explanations or "advance[d] their problem-solving efforts beyond the mode of complaint, question, and informational response." 314 Whereas West Traxton residents often worked out ameliorative strategies with police and followed up with their own or officers' police progress reports at subsequent meetings, east-side residents rarely got beyond "informational" interactions. ${ }^{315}$ As a result, the types of problems that police later pursued tended to be annoyances rather than underlying systemic issues-West, rather than East, Traxton concerns. ${ }^{316}$

Midway through Fung's observations, however, the Traxton meetings changed. ${ }^{317}$ A more experienced volunteer meeting leader took over and-following suggested CAPS protocols-restructured the conversation as a self-conscious exercise to identify and tackle the single most serious challenge facing the entire neighborhood. ${ }^{318}$ Based on complaints east-siders had voiced at earlier meetings, a West Traxton resident identified an East Traxton crack den as the most serious problem, prompting other west-siders to join in addressing what quite evidently was a more serious issue than those that previously dominated the meetings. ${ }^{319}$ The shift toward "structured deliberation" triggered more participation from previously underrepresented community members and highlighted group priorities rather than concerns driven by the most assertive and adroit participants. ${ }^{320}$ Over time, Traxton residents from both areas became more adept at problem identification, prioritization, and solving, forming committees to "negotiate agreements with troublesome landlords, to testify in housing and criminal court, and to conduct 'beat walks' to show resident solidarity and publicly [assess] area problems." ${ }^{321}$ East- and west-side neighbors began to work together, augmenting and cultivating the east-side residents' political capacities. ${ }^{322}$ Structured interactions equalized participation and leveled the political

314. See id. at 185.

315. Id. at $185-87$.

316. Id.

317. Id. at $187-88$.

318. Id.

319. Id. at 188-90, 193.

320. See id. at 193-95.

321. Archon Fung, Street Level Democracy: Pragmatic Popular Sovereignty in ChicAGo Schools ANd Policing 14 (1999), http://www.archonfung.net/papers/sld99.pdf.

322. FUNG, supra note 35, at 196-97 ("During the second, more successful period of observation, however, we saw East Traxton residents together with police and other residents utilize several mechanisms of participatory deliberation."). 
playing field in the meetings. ${ }^{323}$

To be sure, the Traxton experience has not been wholly pervasive. A report on the ten-year anniversary of CAPS gave some beat meetings poor marks for public involvement and found attendance to be skewed toward older and more educated participants. ${ }^{324}$ Still, the example suggests how skilled facilitation and carefully structured deliberation can overcome inequalities in deliberative capacity among diverse stakeholders with a range of problems.

\section{Special Education in Finland}

Special education in Finland exemplifies stakeholder mobilization on a national scale in the context of public education. Systemic changes to schooling at central and local levels have contributed to exceptional academic outcomes for Finnish students compared to their counterparts in other countries, especially among the lowest-scoring quintile of students. ${ }^{325}$ Although these results are often explained by cultural factors - including a deep respect for learning and for student and teacher autonomy - those same cultural factors have not generated comparable results in other Nordic countries, suggesting that education policy is largely responsible. ${ }^{326}$

Finland is notable for carefully structured and monitored educational experiences that are unusually tailored to the learning needs of individual students. ${ }^{327}$ Starting at age two-and-a-half, Finnish children undergo frequent diagnostic assessment using tools co-designed by teachers and universities to facilitate the early detection of learning difficulties and development of individualized intervention plans. ${ }^{328}$ Roughly 30 percent of Finnish school children receive special education services of this sort, either in the short term or intensively over a longer term. ${ }^{329}$

Teams known as student welfare groups (SWGs), which include school principals, psychologists, nurses, special education teachers, and representatives from the municipal administration, provide special

323. See id. at 194-96.

324. Wesley G. Skogan \& Lynn Steiner, Chi. Cmty. Policing Evaluation Consortium, CAPS at Ten: An Evaluation of Chicago's Alternative Policing Strategy iii, 154 (2004), https://portal.chicagopolice.org/i/cpd/clearpath/Caps10.pdf.

325. OECD, PISA 2012 RESULTS IN FocUS, 14 (2012), http://www.oecd.org/pisa/keyfindings/ pisa-2012-results-overview.pdf (citing Finland as proof that "high average performance and equity are not mutually exclusive").

326. Sabel et al., supra note 298, at 3-4 (concluding that "no feature of Finnish cultureneither love of learning nor respect for teachers - can explain current performance").

327. Id. at 7 .

328. Id. at 5-6.

329. Id. at 6. 
education services directly to students. ${ }^{330}$ Teachers, who experience their students' learning styles and outcomes every day, consult with experts to update students' study plans. ${ }^{331}$ The SWGs review teachers' work to benchmark plans and practices against each other and ensure that individual education plans for each student incorporate effective practices. ${ }^{332}$

The National Board of Education (NBE) creates and annually evaluates a core curriculum for Finnish public schools and funds training for all and especially special education teachers, principals, and SWG members. ${ }^{333}$ Informally, NBE converts lessons learned from interactions with schools into proposed changes to national education law, transferring information from local units to the central government and, through changes in national policy, to other schools. ${ }^{334}$

In an important respect, however, the iterative process crucial to DE does not reach its full potential through the Finnish educational system. Although the government monitors student outcomes for regional and social differences, it does not track and compare results of individual schools. ${ }^{335}$ It thus has no systematic way to spot and generalize especially promising practices in individual schools into practices other schools and municipalities can adapt for their own use. ${ }^{336}$

\section{Concerns}

These examples demonstrate DE's potential and highlight some concerns. Although DE demands more in the way of stakeholder participation than casting a ballot or paying interest-group dues, these examples show that iterative problem-solving can be used to build the capacity of even inexperienced participants - addicted offenders, lowincome residents of crime-ridden neighborhoods, parents of specialneeds children - to steer government action toward beneficial solutions. In particular, the Traxton and Finland examples reveal how DE structures can mobilize hard-to-reach stakeholders and align them with team members who can help them use tools and available data to generate solutions.

Although not fully tested, the concern that DE is compromised by its reliance on participants who only temporarily engage does not appear to be borne out in practice. In the drug court example, though offenders

330. Id.

331. Id.

332. Id.

333. Id. at 7.

334. Id.

335. Id. at 17 .

336. Id. at 52 . 
either succeed, advancing out of the system or fail and go to prison, the learning associated with each case is absorbed not only by offenders themselves but also by repeat players: courts, lawyers, and social service providers. ${ }^{337}$ Similarly, in the Finland example, children and parents constantly shift, but SWG members - principals, teachers, nurses, etc.build capacity to effect change school-wide, which Finland could extend system-wide by adding structures for identifying better-performing schools. Nor has the instability inherent in the constant updating of environmental goals and presumptive procedures based on the results of myriad local plans neutralized the effectiveness of the environmental regimes described above.

Still, none of the examples completely resolves concerns about facilitating meaningful participation and addressing disparate levels of stakeholder capacity in large urban school districts where constituents are harder to reach, less ready to participate, or simply intransigent for fear of undermining their stake in the old regime. Unlike at Toyota, most stakeholders in urban school districts are not captive participants for whom "continuous improvement" is an essential part of their job training and workday, and they have no history of stakeholder-driven improvements to warrant faith in the process. Nor, unlike in the drug courts and environmental case studies, are most school district stakeholders drawn in by a court order, a "cause," or an immediate and palpable impact on their property or livelihood.

A final concern is the complexity and scope of the problems to be solved. To be sure, the case studies above address issues of great importance and difficulty. Still, production errors in car manufacturing, antisocial behavior tied to drug addiction, and even urban crime may have fewer key dimensions and better defined and accepted improvement goals and strategies than the problems facing U.S. public education. ${ }^{338}$

\section{Democratic EXPERIMENTALISM IN-AND Not IN-PUBliC EDUCATION TODAY}

This Part argues that the new education reforms adopt DE governance but disregard its new forms of politics. Instead, by endeavoring to practice no politics at all, the reformers have left educators, parents, and other stakeholders with no collective way to interact with the reforms

337. See supra Subsection III.C.2.

338. See Wendy Kopp, Do American Schools Need to Change? Depends What You Compare Them to, ATLANTIC (Oct. 25, 2013), http://www.theatlantic.com/education/archive/2013/10/doamerican-schools-need-to-change-depends-what-you-compare-them-to/280768/ (contrasting two best-selling education authors: "[Diane Ravitch] dismisses international tests like PISA and compares the U.S. to its own education track record ... [concluding there isn't] much cause for alarm ... [;] [t]o [Amanda] Ripley, international standards are the relevant ones in a globalized information economy," leaving much for Americans to fear). 
except through a particularly virulent form of traditional interest-group politics. In other words, implementation of new forms of governance against the backdrop of old forms of civic engagement has generated fierce and counterproductive conflict. To be sure, many objections to the reforms are from special interests whose influence the reforms diminish. But the reforms also face powerful objections from the populations they aim to serve, confirming that something is seriously amiss politically, and that the reforms are not simultaneously democratic and experimentalist.

\section{A. Experimentalist Governance and the Promise of the New Education Reforms}

$\mathrm{DE}$ is the alternative to bureaucratic governance that best explains the new education reforms and their promising results. A common feature of the reforms - often ordered by a mayor vested with responsibility previously exercised by an elected school board - is the empowerment of school leaders and educators to make instructional and management decisions previously assigned to powerful central bureaucrats under the loose supervision of the board and a short-term superintendent. ${ }^{339}$ Like other experimentalist arrangements, that is, the new education reforms aim to free field staff-here, principals and teachers - from bureaucratic constraints and empower them to address the diverse local conditions that, although invisible to central experts, inevitably frame the most urgent problems and effective solutions. ${ }^{340}$ To motivate and inform educators' use of their heightened authority to accelerate student learning across all populations, districts compare similarly situated schools based on students' rates of course-credit accumulation, longitudinal growth in standardized test outcomes, graduation, and college attendance and use consumer surveys and qualitative review of schools' environmental features and management processes thought to drive improved outcomes. $^{341}$

Supported by central-office supervisors retooled as facilitators, collaborative-inquiry teams within and across schools use the same information and shorter-term diagnostic assessments to identify patterns and causes of strong or weak learning outcomes and to devise plans for struggling students, teachers, and schools that become the basis for further inquiry, adjustment, and sharing among schools. ${ }^{342}$ Results also inform decisions to close chronically underperforming schools,

339. See, e.g., supra notes 84, 91-92, 104, 160-62 and accompanying text.

340. For examples of the reforms' exchange of local autonomy for accountability in Baltimore, Boston, Charlotte, Denver, and New York, see supra notes 104-05, 107-08, 112, 127$28,162$.

341. See, e.g., supra notes 127, 136, 139 and accompanying text.

342. See supra notes $139-40$ and accompanying text. 
proliferate promising new school models, and expand family choice among schools. ${ }^{343}$ Overall, the district's role changes from command and control to motivation, facilitation, and portfolio management, and schools and educators move from rule following to accountable experimentation and innovation. Although outcomes vary, the reforms as a whole have improved teacher quality, raised test scores, and increased graduation and college-going and success rates. ${ }^{344}$

True, other alternatives to bureaucracy can explain the reforms' reliance on consumer choice and allowance of grossly underperforming schools to close (marketization), ${ }^{345}$ use of consequential, centrally defined targets to hold local units accountable (managerialism), ${ }^{346}$ and emphasis on collaboration among empowered practitioners (professionalism/craft). ${ }^{347}$ Only experimentalism, however, can explain the confluence of all these features, ${ }^{348}$ some of which are anathema to other models. ${ }^{349}$ Most crucially, experimentalism alone validates four simultaneous beliefs about the knowledge needed to solve collective problems-beliefs that the reforms manifest in their penchant for quantitative and qualitative assessment and data, structured team-based inquiry, and feedback loops:

- Institutions can, and to succeed must, make knowledge explicita belief experimentalism shares only with bureaucracy.

- All individuals affected by a problem have knowledge crucial to its solution-a belief experimentalism shares only with marketization.

- All individuals can effectively participate in using their own and others' knowledge to respond to a problem's impact on their individual and collective needs and values - a belief experimentalism shares with no other model.

- Proliferating local experimentation and structuring it to make its steps and results visible, actionable, and accountable to teams of

343. See supra notes 129,146 and accompanying text.

344. See, e.g., supra notes 106, 110, 113, 142-46, 172 and accompanying text (referencing outcomes in Baltimore, Boston, Charlotte, Denver, and New York City).

345. See, e.g., Choices \& Enrollment: High School, N.Y.C. DEP'T Educ. (describing high school choice in New York City); supra notes 112, 129 (citing school choice in Denver and closure of failing schools in New York City).

346. See supra notes 112, 127, 218-22 and accompanying text (describing managerialist tendencies of reforms in Denver and New York City).

347. See supra notes 230-32 and accompanying text (describing professionalism-based reforms).

348. See supra notes 112, 129 (choice, school closure), 127 (consequential targets), 139 (collaborative inquiry) and accompanying text.

349. See supra notes 196-97, 218-22, 240-47 and accompanying text (discussing ways the new reforms depart from marketization, managerialism, and professionalism/craft). 
local problem-solvers, central observers, and other sites facing analogous problems are the best way to maximize knowledgealso unique to experimentalism. ${ }^{350}$

There also is evidence - causally inconclusive, to be sure-linking the reforms' experimentalist features to their qualified success. ${ }^{351}$ Particularly clear is the association between those results and the reforms' use of transparent and consequential student outcomes to motivate and facilitate improvement. For example, two rigorous, quasi-experimental studies of New York City's consequential school accountability system found "positive, statistically significant, and economically meaningful impacts on student achievement" over the course of the next school year in schools that had received failing grades for student achievement in math or English the prior year. ${ }^{352}$ Although both studies focused on lowperforming schools, other evidence links the reforms to student gains in reading and math across the entire system. ${ }^{353}$

If consequential accountability alone drove the new reforms, marketization or managerialism might as easily explain these results, but evidence suggests otherwise. For example, mayoral control-a managerialist feature of certain reforms - only sometimes correlates with success, and the predominance of experimentalist governance structures may explain the difference. ${ }^{354}$ Professors Kenneth K. Wong and Francis $X$. Shen's careful study of city-versus-state results in eleven mayoralcontrol districts contrasts impressive and sustained student learning gains in New York City in the 2000s with Boston's more modest gains, which soon lost "momentum." 355 These results mirror the two districts" divergent investment in diagnostic uses of data, which was greater in New York than in Boston. Indeed, reforms in four of the five mayor-controlled districts that substantially closed the achievement gap with the rest of their states are strongly associated with experimentalist strategies, unlike the four districts with more modest results and the two districts where

350. For a discussion of each model's treatment of knowledge, see supra text accompanying notes 188 (marketization), 208 (managerialism), and 223 (professionalism/craft).

351. See supra note 348 and accompanying text.

352. Marcus Winters, Grading New York: An Evaluation of New York City's Progress Report Program, Manhattan Inst. Civic ReP., Nov. 2008, at 1, 7; Jonah Rockoff \& Lesley J. Turner, Short Run Impacts of Accountability on School Quality 2 (Nat'l Bureau of Econ. Research, Working Paper No. 14565, 2008), http://www.nber.org/papers/w14564.pdf.

353. See sources cited supra note 141.

354. See Wong \& SHEN, supra note 85, at 7-8, 22, 25-26 (studying eleven mayoral control districts, five of which substantially narrowed the achievement gap between themselves and the rest of the state, four of which showed some progress, and two of which saw the gap widen).

355. Id. at 7-8. 
city-state achievement gaps widened. ${ }^{356}$ Testing the hypothesis that inquiry teams contributed to its success closing the achievement gap with the rest of the state, New York City found that, across nearly all achievement levels, students on whom inquiry teams focused their improvement efforts outperformed other students who began the year at the same performance level in both reading and math. ${ }^{357}$

Similarly, educational researcher Heather Zavadsky's study of urban school districts that were awarded the Broad Prize for impressive student learning gains and reductions in achievement gaps ${ }^{358}$ links those results to what this Article identifies as experimentalist structures. ${ }^{359}$ For example, she attributes narrowing district-to-state achievement gaps and other beat-the-odds outcomes in the 91-percent black and Hispanic Aldine Independent School District north of Houston to its deployment of a "one-stop" data management system to "identify strengths and weaknesses"; development, monitoring, and frequent adjustment of action plans addressed to students' and schools' "specific needs or objectives"; and specification of goals and actors responsible for reaching them. ${ }^{360}$ She associates similarly impressive results in "urban suburban" Garden Grove Unified School District in California-75 percent of whose mainly immigrant Hispanic students speak English as a second language - with the use of real-time data to spot struggling schools, teachers, and students and of teacher collaboration within and across grades to review data and plan improvements to bring results back on track. ${ }^{361}$ Likewise, educational researcher Michael Fullan and journalist Alan Boyle credit impressive results in Ontario, Canada to its use of data to provide early warning of schools and students needing more support and to capacity-building and problem-solving through structured educator collaboration and information sharing. ${ }^{362}$

356. See supra notes $85-90$ and accompanying text. Among substantially improving mayoral-control districts, Baltimore, Chicago, New Haven, and New York, but not Philadelphia, adopted experimentalist reforms; modestly improving districts Boston and Hartford adopted thin versions of the reforms, while Harrisburg and Providence did not adopt the reforms; gap-widening district Cleveland adopted experimentalist reforms only after the study period; and Yonkers did not adopt them. See WONG \& SHEN, supra note 85, at 1,9-10.

357. New York City DeP'T OF Educ., InQuiry Team Study (2009) (finding that on average one year of inquiry helped target students close 11 percent of the gap in math and 6 percent of the gap in reading between their starting point and the next highest proficiency level under New York State's four-level tracking system) (on file with authors).

358. ZAVADSKY, supra note 212, at xix.

359. See id. at 8 .

360. Id. at $15,23-25,42-43,46$.

361. Id. at $131-32,138-40,148,157$.

362. Fullan \& BOYLE, supra note 87 , at $68,71,78$. Supporting these conclusions are six characteristics of Arizona elementary and middle schools where students performed substantially better on third-grade reading and eighth-grade math tests than students at their demographic peer 
Scientifically comparing the impact of different reforms comprising distinct combinations of partly intersecting treatments is notoriously difficult. Nonetheless, the evidence tends to link student learning gains and experimentalist education reforms based on iterative problemsolving motivated by transparent accountability and driven by collaborative educator teams' structured analysis of information to spread effective, adjust partly effective, and abandon ineffective policies.

\section{B. The Absence of Experimentalist Politics and Risk of the Reforms' Demise}

This Article has attributed contemporary systemic problems with public education in the United States to bureaucracy and special-interest politics. Reformers have had some success responding to bureaucratic failings through changes in governance structures. As this Section demonstrates, the same cannot be said for changes in pluralist politics.

\section{A New Vision of Education Politics}

The problem begins with the standard account of educational politics, which has no place for DE. Using the figure below, political scientist Jeffrey Henig has explained education politics in New York City as a matrix that divides political engagement into two types (individualistic versus collective) and two focuses (policy implementation versus policy formation). ${ }^{363}$ Individualistic policy implementation (Cell $\left.A\right)$ encompasses direct interactions between school district and families to effectuate school policy, as when families use district procedures to exercise choice among schools. ${ }^{364}$ Individualistic policy formulation (Cell B) covers collaborative interactions between teacher and family over the instruction of particular children, as in parent-teacher conferences. ${ }^{365}$ Collective policy implementation $(\mathrm{Cell} C)$ includes PTAs

schools and students statewide: Under the direction of (1) strong principals, who (2) stuck with the program, the schools (3) set clear goals, (4) used an array of formative assessments, and (5) structured collaboration among educators (6) to identify instructional and programmatic weaknesses and engage in iterative cycles of instruction, assessment, evaluation, and intervention to identify, test, and improve solutions. MARY Jo WAITS ET AL., CTR. FOR THE FUtURE OF ARIZ, Why Some Schools with Latino Children Beat the OdDS ... And Others Don't 7, 25, 28, 31 , 33 (2006), http://www.beattheoddsinstitute.org/pdf/FAZ502_LatinEd_final.pdf; see also id. at 48 (concluding that these results are not attributable to the intuitive, "word of mouth" collaboration among master practitioners that professionalism and craft favor and urging schools to institutionalize explicit transfers of information).

363. Henig et al., supra note 90 , at 5 .

364. Id.

365. Id. 
and School Leadership Teams. ${ }^{366}$ Finally, noting New York's adoption of mayoral control, Henig divides the fourth category, collective policy formulation, in two: classic interest-group politics, which Henig calls "advocacy, strong democracy" and prefers (Cell D), and "mayoral election," which Henig criticizes for submerging educational politics in a sea of non-education concerns (Cell E). ${ }^{367}$

Education Politics

\begin{tabular}{|l|l|l|}
\hline & \multicolumn{1}{|c|}{ Implementation } & Policy Formulation \\
\hline Individualistic & A. Information, service, & B. Child-centered collaboration \\
complaints, choice & C. Supportive partnerships & D. Advocacy, strong democracy \\
\hline Collective & E. Mayoral election \\
\hline
\end{tabular}

As is described in Part III above, DE erases the lines separating all the cells. It understands policy formulation as a function primarily of carefully observed and repeatedly adjusted implementation. ${ }^{368}$ Furthermore, it treats the identification and attempts to solve each individual problem as a contextualized experiment in clarifying the collective problem and solution through a process of coordinated action and collective accountability. ${ }^{369}$ Experimentalism thus occupies the vast center of Henig's matrix. ${ }^{370}$

Idealized and transported to the education context, DE imagines an "ethical situation" 371 in which groups of parents and educators temporarily shed interests and ideological commitments and engage with each other and with school leaders in a collaborative process of identifying and improving solutions to an instructional or related problem of importance to all. ${ }^{372}$ Conflict is minimized and multiple perspectives are leveraged in a process disciplined by agreement to limit discourse to that problem and to premise judgment on a single metric: whether proposals clarify the problem and contribute to its solution.

366. Id. at 6 .

367. Id. at 5-6; see also FULLAN \& Boyle, supra note 87, at 44-45, 71, 101 (limiting the conception of school politics to pluralist political structures, e.g., school leadership teams, community education councils, and collective bargaining); Keith Robinson \& Angel L. Harris, Parental Involvement Is Overrated, N.Y. TiMEs: OpINIONATOR (Apr. 12, 2014, 2:32 PM), $\mathrm{http}$ ://opinionator.blogs.nytimes.com/2014/04/12/parental-involvement-is-overrated (limiting the conception of parental involvement to parent-teacher conferences, PTA meetings, and voicing agreement or opposition at public meetings).

368. See supra Section III.A.

369. See supra Section III.A.

370. See supra Section III.A.

371. See supra Section III.A; infra Part V.

372. See supra Section III.A. 


\section{The Sobering Reality of Education Politics}

This version of DE engagement bears little resemblance to politics occurring on a wide scale in education today, especially in reform states and districts. Rather than dampening conflicts, the reforms have inflamed them. Far from engaging in warm collaborations on improvements in the collective good, the stakeholders in whose names the reforms have occurred feel frozen out of "corporate," "disruptive," and "technocratic" strategies they don't understand or trust. ${ }^{373}$ In reformers' haste to release schools from the stranglehold of special-interest politics, they have refused to engage the body politic at all. ${ }^{374}$ As a mother and member of a community education board said in the midst of New York City's reforms, "I think [reformers] have done a good job getting rid of the bad political stuff . . . . It's just that they've gotten rid of everything else, too." 375

Over time, a "governance structure" seen as "eliminat[ing] community influence on legitimate matters of concern" and any "effective way for parents to address systemic issues" backfired. ${ }^{376}$ The goal was perhaps admirable: to cut off all avenues for pluralist - or any substitute - politics in hopes that more choice among schools, better service, and rising test scores would satisfy consumers. As Michelle Rhee confessed after being forced out as schools chancellor in Washington, D.C., "I . . . thought, 'Well, OK, if we put our heads down and do the work, after two years we'll have great results, and everybody would be

373. Ta-Nehisi Coates, Michael Bloomberg Is Not a Scientist, Man, AtLanTIC (Sept. 9, 2013), http://www.theatlantic.com/politics/archive/2013/09/michael-bloomberg-is-nota-scientist-man/279455/ (labeling Mayor Bloomberg's "technocratic" approach to "school reform" an " affront to democracy"); Joe Flood, Bloomberg's Blind Spot: Technocrat Mayor Overstocks Laboratory of Ideas, N.Y. MAG. (Dec. 23, 2010), http://nymag.com/ news/intelligencer/70313; Stuart Whatley, Disrupt Yourself (And Do Us All a Favor), L.A. ReV. BooKs (Mar. 28, 2014), https://lareviewofbooks.org/essay/disrupt-us-favor (criticizing selfproclaimed "disruptive" reforms as "neoliberal" efforts to enable managerialist elites to control schools); Diann Woodard, The Corporate Takeover of Public Education, HufFington Post (Aug. 6, 2013, 2:34 PM), http://www.huffingtonpost.com/diann-woodard/the-corporate-takeover_ b_3397091.html; see sources cited supra note 25 .

374. HEMPHILl \& NAUER, supra note 284 , at 40.

375. Id

376. Id.; see id. at 41 (“'It renders everyone powerless except the people in charge. ... No parent group, no assemblyman can influence anything." (quoting Diane Ravitch)); Natalie Gomez-Velez, Public School Governance and Democracy: Does Public Participation Matter?, 53 ViLL. L. REV. 297, 348 (2008) (describing Bloomberg's view as "because he is accountable, he is empowered to make decisions unilaterally under a minimalist conception of democratic legitimacy"); sources cited supra note 25 . 
happy. ${ }^{, 377}$ But the reality is different: improved results take time and are viewed with skepticism by a public scarred by decades of failed schools, false promises, and black-box solutions. Even if - as sociologist William Julius Wilson wrote in defense of Rhee-her impatience to free students "locked in a lousy school system" was "the ultimate display of respect for African-American residents in Washington, showing exactly how far [its leaders were] willing to go [to] improve urban education," ${ }^{378}$ the impression left was one of disengagement, elitism, and disrespect. ${ }^{379}$

Emblematic of the reforms' political failure is their typical approach to closing schools, which have left minority communities feeling not only confused and excluded but also robbed of precious, if tarnished, neighborhood institutions. ${ }^{380}$ As sensible as it is to shutter schools where poor and minority children's 'test scores, attendance, graduation rates, and readiness for college" have for years fallen below anyone's minimum standard, ${ }^{381}$ doing so has sparked fierce opposition not only from unions and community boards that stand to lose members and patronage, but also from the students and parents the schools directly harm. ${ }^{382}$ Absent

377. Dakarai I. Aarons, Rhee Reflects on Her Stormy Tenure in D.C., EDUC. WK. (Sept. 17, 2010), http://www.edweek.org/ew/articles/2010/09/17/04rhee_ep.h30.html (quoting Michelle Rhee); see KLEIN, supra note 213, at 254.

378. William Julius Wilson, Letter to the Editor, How a School Chief Tried to Turn a District Around, N.Y. TimES (Sept. 23, 2010), http://www.nytimes.com/2010/09/24/opinion/124 herbert.html.

379. See Bob Herbert, Neglecting the Base, N.Y. Times (Sept. 20, 2010), http://www.nytimes.com/2010/09/21/opinion/21herbert.html (describing Rhee's reforms as disrespectful to the black community); see also Warner, supra note 20 ("[P]eople . . . don't like to get the message that their communities are on the wrong track ... [from] stern-faced do-gooders telling them how to think and what to do.").

380. Trymaine Lee, Amid Mass School Closings, a Slow Death for Some Chicago Schools, MSNBC (Dec. 27, 2013, 7:56 AM), http://www.msnbc.com/msnbc/dont-call-it-school-choice.

381. Philissa Cramer \& Rachel Cromidas, Among 24 Schools City Says It Could Close, Some Familiar Names, CHALKBEAT (Nov. 26, 2012), http://ny.chalkbeat.org/2012/11/26/city-says-it-isconsidering-closing-24-high-schools-this-year; see id. (profiling Walter Dyett High School on Chicago's south side where only 6.5 percent of eleventh graders meet or exceed state standards in reading, math, and science); see also Beth Fertig, In One NYC School, A Snapshot of Bloomberg's Education Legacy, NPR (Dec. 18, 2013, 2:39 PM), http://www.npr.org/2013/ 12/18/255259953/in-one-nyc-school-a-snapshot-of-bloombergs-education-legacy (reporting that during New York City reforms, Mayor Bloomberg closed nearly 200 schools); Sharon Otterman, Large High Schools in The City Are Taking Hard Falls, N.Y. TiMES (Jan. 25, 2010), http://www.nytimes.com/2010/01/26/nyregion/26closings.html (comparing high schools closed by Bloomberg administration, which often had four-year graduation rates below 40 percent, to 60 percent rate citywide and 75 percent rate at new small schools with which Bloomberg replaced the closed schools).

382. See, e.g., Philissa Cramer, Brouhaha in Brooklyn: Live-Blogging the PEP's School Closure Vote, CHALKBEAT (Jan. 26, 2010), http://ny.chalkbeat.org/2010/01/26/brouhaha-inbrooklyn-live-blogging-the-peps-school-closure-vote (chronicling a night of protests closing down streets for hours, nine hours of testimony from elected officials, parents, teachers, and 
effective engagement in decisions to close existing and design replacement schools, parents and students see the closures as theft of their social capital, destroying institutions that for decades have been the neighborhoods' "only [source of] stability," jobs, and even their names. ${ }^{383}$ No wonder, then, that affected communities often perceive decisions to close schools as new manifestations of neglect and racism. ${ }^{384}$

Ironically, by excluding the reforms' intended beneficiaries from their design and implementation, while leaving the special-interest politics the reforms aimed to sideline as the only political game in town, reformers have driven their most likely allies into their opponents' embrace. Although fueled by the anger of largely unorganized families and students, the resulting protests have typically taken classically interestgroup forms and been effectively exploited by established special interests.

These responses to the reforms' calculated political neglect have put the entire reform enterprise at risk, driving reform mayors, district superintendents, and state education commissioners out of office and triggering the defeat of reform referenda in California, Connecticut, Florida, Idaho, Indiana, New Jersey, Los Angeles, New York City, and Washington, D.C., among others. ${ }^{385}$ Even concerted efforts to soft-pedal

students, and, finally, a vote to close all nineteen schools discussed); Anna Phillips, Hundreds Turn out to Protest Plans to Close Jamaica High School, Chalkbeat (Dec. 17, 2009), http://ny.chalkbeat.org/2009/12/17/hundreds-turn-out-to-protest-plans-to-close-jamaica-highschool ("Hundreds of angry students, parents, and teachers packed Jamaica's auditorium last night to protest the Department of Education's plan to close the school."); Claudio Sanchez, Layoffs at Ailing D.C. Schools Spark Union Outrage, NPR (Oct. 16, 2009, 12:12 AM), http://www.npr.org/templates/story/story.php?storyld=113791976 (“At last week's rally, lots of students and parents showed up to support teachers and their union ....").

383. Lee, supra note 380.

384. See, e.g., Noreen S. Ahmed-Ullah \& John Byrne, Fewer Than 5 CPS Schools Expected to Be Spared, CHI. TRIB. (May 21, 2013), http://articles.chicagotribune.com/2013-05-21/news/ctmet-school-closing-march-0521-20130521_1_closings-list-schools-chief-barbara-byrd-bennettpresident-david-vitale ("[Chicago Teachers Union-led] demonstrators . . . circle[d] City Hall, chanting 'Hey Rahm, let's face it, these closings are racist ...."”); Emma Brown, Activists Sue to Stop D.C. School Closures, WASH. Post (Mar. 29, 2013), https://www.washingtonpost.com/ local/education/activists-file-lawsuit-to-stop-dc-school-closures/2013/03/29/3310ab5a-988a11e2-b68f-dc5c4b47e519_story.html ("Activists ... filed a lawsuit . . . arguing that the closures disproportionately affect poor, minority and disabled students."); Jennifer Medina, N.Y. Senate Renews Mayor's Power to Run Schools, N.Y. Times (Aug. 6, 2009), http://www.nytimes.com/ 2009/08/07/nyregion/07control.html (“"The elephant in the room: race and class,' said Senator Bill Perkins of Manhattan [discussing school closures].”).

385. See, e.g., Josh Eidelson, Michelle Rhee Revolution Faces Massive Threat-and New Accusations, SALON (Nov. 4, 2013, 8:30 AM), http://www.salon.com/2013/11/04/how bipartisan_antics_could_save_the_next_michelle_rhee_from_humiliation (describing nationwide backlash against reforms); Scott Elliott, Here's What Tony Bennett Thinks of His Critics, ChalkBeat (Apr. 4, 2014), http://in.chalkbeat.org/2014/04/04/heres-what-tony-bennett-thinks- 
reform initiatives, as in Denver, or to conciliate interest-group opponents, as in New York State, have engendered turbulence that has put the reforms at risk notwithstanding evidence that they are working. ${ }^{386}$

Worse even than the debilitating political opposition such political neglect has engendered ${ }^{387}$ are harms the reforms have exacted on themselves by shutting off pathways for community input. The reforms' secret sauce is their ability to mobilize localized information revealing the conditions for which strategies must account if they are to succeed. ${ }^{388}$ If the reforms ignore what parents and communities know, the sauce becomes a thin, unsatisfactory gruel.

Nor have these problems been mitigated by a new crop of advocacy groups the reforms have germinated, with names like Families for Excellent Schools, Parent Revolution, Stand for Children, and StudentsFirst. ${ }^{389}$ In the main, these groups either focus on mobilizing families to interact more effectively with educators in support of their own children (Henig's Cell B), ${ }^{390}$ or rely on new forms of old interest-

of-his-critics (discussing resignation of Indiana's reform-minded schools commissioner); Herbert, supra note 379 (claiming black community responded to school reforms under Washington Mayor Adrian Fenty and schools Chancellor Rhee "by voting overwhelmingly for Mr. Fenty's opponent, Vincent Gray," who defeated Fenty); Iavesoli, supra note 2 (chronicling Los Angeles reform superintendent John Deasy's resignation following controversies over using "data through an equity lens," teacher evaluation, and restructuring of struggling schools); Linda Conner Lambeck \& Brian Lockhart, Vallas to Resign to Run for Illinois Lt. Gov., NewsTimes (Nov. 8, 2013, 10:33 PM), http://www.newstimes.com/local/article/Vallas-to-resign-to-run-for-Illinois-lt-gov4969174.php (discussing resignation of Bridgeport schools superintendent); Kathleen McGrory \& Jeffrey S. Solochek, Tony Bennett Resigns as Florida Education Commissioner, TAMPA BAY TiMES (Aug. 1, 2013, 8:53 AM), http://www.tampabay.com/news/education/k12/floridaeducation-commissioner-tony-bennett-expected-to-resign-today/2134254; Mark Pazniokas, Stefan Pryor to Leave Education Post After One Term, CT. Mirror (Aug. 18, 2014), $\mathrm{http} / /$ ctmirror.org/2014/08/18/stefan-pryor-to-leave-education-post-after-one-term (attributing resignation of Connecticut school commissioner to opposition to his reform policies); Diane Ravitch, Luna Laws in Idaho Go Down to Stunning Defeat, Diane Ravitch's Blog (Nov. 7, 2012), http://dianeravitch.net/2012/11/07/luna-laws-go-down-to-defeat (describing referendum defeat of teacher evaluation initiatives); Elaine Weiss, Voters Gave Corporate Education "Reform" a Big Defeat on Election Day, MOYERS \& Co. (Nov. 14, 2013), http://billmoyers.com/ 2013/11/14/voters-gave-corporate-education-reform-a-big-defeat-on-election-day (describing defeat of Bridgeport education reform referendum); Kate Zernike, Cami Anderson, Picked by Christie, Is out as Newark Schools Superintendent, N.Y. TIMES (June 22, 2015), http://www.nytimes.com/2015/06/23/nyregion/newark-schools-superintendent-is-steppingdown.html.

386. See supra Section I.C.

387. Warner, supra note 20.

388. See supra Part III \& Section IV.A.

389. Katie Ash, Newer Advocacy Groups Find Foot Soldiers in Parents, Educ. WK. (Dec. 23, 2013), http://www.edweek.org/ew/articles/2013/12/23/15parents.h33.html.

390. See Henig et al., supra note 90, at 5; see, e.g., Stand University for Parents, STAND FoR CHILD., http://stand.org/national/action/stand-up/about (last visited Mar. 19, 2017) (discussing 
group politics to beat existing special interests at their own game (Henig's Cell D). ${ }^{391}$ StudentsFirst, Michelle Rhee's creation after she left the D.C. school system, is illustrative. ${ }^{392}$ Although StudentsFirst rejects the interest-group label, ${ }^{393}$ it acts like one, having formed related section $501(\mathrm{c})(3), 501(\mathrm{c})(4)$, and 527 organizations and a political action committee and spending millions of dollars - much of it from donors known for their large contributions to presidential campaigns - to train parents to lobby for favored reforms, bus parents to rallies, and fund candidates in local and state elections. ${ }^{394}$

Among reform-oriented advocacy organizations, only Parent Revolution and the "parent trigger" laws it works to enforce suggest a new politics. First enacted in California in 2010 and in force in several states, parent trigger laws allow parents who collect sufficient numbers of signatures to force the restructuring or closure of low-performing schools. ${ }^{395}$ In theory, therefore, the laws could give parents-and Parent

organization's Stand UP program for guiding parents in forming relationships with schools, understanding student data and grades, and helping children learn at home).

391. See, e.g., Ash, supra note 389 (describing Families for Excellent Schools' recruitment and training of parents to lobby for charter school expansion in New York and Connecticut); Stephen Sawchuk, Relationship Between Advocacy Groups, Unions Uneasy, Educ. WK. (May 21, 2012), http://www.edweek.org/ew/articles/2012/05/23/32adv-union_ep.h31.html (describing Stand for Children's shift from advocacy for increased educational spending to using section 501(c)(3) and 501(c)(4) organizations, PACs, and "super PACs" in "aggressive entry into state politics" on behalf of school reforms); see also supra notes 363-67 (discussing Henig's categories of education politics).

392. Joy Resmovits, Michelle Rhee's Backers Include Obama Bundler Billionaire, Big Romney Backer, Huffington Post (Mar. 9, 2012, 5:16 PM), http://www.huffingtonpost.com/ 2012/02/24/michelle-rhees-backers-in_n_1300146.html.

393. See Ash, supra note 389.

394. See id. (describing StudentsFirst lobbying efforts); Steven Mazie, StudentsFirst Gives NY Ed Commissioner a Friendly Audience for Common Core Forum, WASH. Post: ANSWER SHEET (Dec. 11, 2013), http://www.washingtonpost.com/blogs/answer-sheet/wp/2013/12/11/ studentsfirst-gives-ny-ed-commissioner-a-friendly-audience-for-common-core-forum/ (describing "carefully scripted" StudentsFirstNY lobbying by parents and teachers bused in for event); Resmovits, supra note 392; Stephen Sawchuk, StudentsFirst Raises \$7.6 Million in 2010 11, EDUC. WK. (June 25, 2012, 4:48 PM), http://blogs.edweek.org/edweek/teacherbeat/2012/ 06/studentsfirst_raises_76_millio.html (detailing StudentsFirst's successful initial fundraising and creation of affiliated organizations for educational, lobbying, and partisan political purposes); DEP' T OF TREASURY IRS, STUDENTSFIRST RETURN OF ORGANIZATION EXEMPT FROM INCOME TAX: IRS FORM 990, at 1-2, http://990s.foundationcenter.org/990_pdf_archive/273/273659685/ 273659685_201207_9900.pdf (reporting \$3,289,994 in spending on electoral activity in 2011 and 2012).

395. Josh Cunningham, Parent Trigger Laws in the States, NAT'L CONF. ST. LeGiSLATURES (Oct. 15, 2013), http://www.ncsl.org/issues-research/educ/state-parent-trigger-laws.aspx (summarizing parent-trigger laws, including California's, which requires districts to implement one of four turnaround models parents choose if 51 percent of them sign a petition demanding change at a school defined as low-performing). For contrary views on parent trigger laws, compare 
Revolution has worked to help them secure-a potentially experimentalist foothold in district decision-making on struggling schools. ${ }^{396}$ Thus far, however, the laws have mainly triggered ruthless pluralist politics. In Compton, California, for example, parents' efforts, with Parent Revolution support, to replace McKinley Elementary with a charter school generated strife with the teachers' union and a district lawsuit that threw out the petition for lack of verification that the signatories (in a community with many undocumented immigrants) were parents. ${ }^{397}$ As a rule, therefore, the new reform-minded advocacy efforts have aggravated, rather than replaced, special-interest politics. ${ }^{398}$

As these political setbacks and recriminations reveal, promising reforms that are experimentalist from a governance perspective fall short of democratic experimentalism from a political perspective. By insulating governance from politics - separating stakeholders from decision-makers and leaving no route for engagement except traditional interest-group channels - reformers threaten the gains their governance innovations have already achieved and might otherwise multiply in the future. As the next Part develops, however, this bifurcation is not inevitable.

\section{A MoRe DEMOCRATIC EXPERIMENTALIST REGIME FOR PUBLIC EDUCATION}

Thus far, this Article has described the damage that centralized bureaucracies and pluralist politics inflict on U.S. public education; shown that accepted alternatives to centralization-markets, managerialism, and professionalism/craft — enhance local flexibility only by sacrificing the actionable knowledge that bureaucracies can sometimes crystallize and leave special-interest politics intact; praised democratic experimentalism for using structured exercises of local

AnNenberg Inst. For Sch. Reform, Parent Trigger: No Silver Bullet 1, 3,6 (2012), http://annenberginstitute.org/pdf/ParentTriggerPolicyBrief.pdf, with JOSEPH L. BAST ET AL., Heartland Inst., The Parent Trigger: A Model for Transforming Education 1-2, 5, 13 (2010), http://heartland.org/sites/all/modules/custom/heartland_migration/files/pdfs/28202.pdf.

396. See BAST ET AL., supra note 395, at 1-2.

397. See David Feith, Triggering School Reform — and Union Dirty Tricks, WaLl St. J. (Feb. 24, 2012, 7:41 PM), http://online.wsj.com/news/articles/SB1000142405297020391830457724 3054128401994; Jim Newton, Compton Parents Trigger Reform, L.A. Times (Feb. 15, 2011), http://articles.latimes.com/2011/feb/15/opinion/la-oe-0215-newton-20110215; Julie Woestehoff, Update on Parent Trigger, PARENTS ACROsS AM. (May 18, 2013), http://parentsacrossamerica. org/update-parent-trigger/.

398. See Errol Louis, A Teachable Moment for Reform, N.Y. Daily News (Sept. 23, 2010, 4:00 AM), http://www.nydailynews.com/opinion/teachable-moment-reform-charter-schoolsupporters-learn-setback-polls-article-1.442989 (urging education-reform groups to jettison counterproductive confrontation and "rethink how, when and why they make the case for change to parents, the public and the press"); Sawchuk, supra note 391 (noting increased friction with unions generated by new reform-oriented advocacy groups). 
flexibility to generate more actionable knowledge than bureaucracy, while unleashing new forms of democratic politics that broadly engage stakeholders and harness their knowledge in local experimentation; and criticized recent public education reforms for limiting their otherwise promising experimentalism to a technocratic and self-defeating version that pretends to have no politics at all. After acknowledging the difficulties that stakeholder engagement presents in the context of public education, this Part uses contemporary examples to show what a more democratic version of experimentalist education reforms can look like.

\section{A. The Challenge of Stakeholder Engagement in Public Education}

Implementing new politics in education presents challenges absent from other domains. Compared to other contexts, there are more stakeholders who are harder to reach and less prepared to engage.

Many examples of well-functioning DE involve a limited and easily identifiable public predisposed to engage in problem-solving. In drug courts, for example, judges, lawyers, and treatment providers participate as part of their jobs, and defendants have a strong incentive to seek treatment instead of incarceration. ${ }^{399}$ The economic, residential, recreational, and values-based interests at stake in environmental protection create similar motivations rooted in participants' immediate quality of life. ${ }^{400}$ Even in community policing, where strategies affect entire neighborhoods and not every potentially important participant is strongly and naturally drawn into the problem-solving "situation," the neighborhood in question limits the range of participants whom the experimentalist agency might try to engage, and assures that the few people who participate are decent proxies for the many who don't. ${ }^{401}$

Drawing stakeholders into problem-solving in $\mathrm{K}-12$ education is not as straightforward, in part because the range of stakeholders is much broader, including students, parents, teachers, administrators, district personnel, community residents, taxpayers, and the wider public, all with different interests. ${ }^{402}$ In addition, many stakeholders are disillusioned by years of broken promises and top-heavy reforms. Parents are, of course, especially important potential problem-solvers, yet given their singleminded concern for their own child's sui generis needs, those who participate may not be close proxies for those who demur. And unlike participants in the drug-court, environmental, and community-policing contexts, parents - perhaps especially those whose children are most in need - may not be sufficiently well-informed about what is at stake for them in the problem-solving process to motivate their participation. As

399. See supra Subsection III.C.2.

400. See supra Subsection III.C.3.

401. See supra Subsection III.C.4.

402. See BAST ET AL., supra note 395 , at 2-3. 
teachers and other school employees are more capable of representing each other and more motivated to participate, the result is structural inequities in how effectively problem-solving addresses their needs compared to those of families.

Capacity - time, resources, and skills - is also necessary for effective participation in the steps that experimentalist problem-solving entails, including problem and solution identification and prioritization, causal analysis, performance measurement, meeting facilitation, and various forms of verbal interaction and deliberation. Many education stakeholders - again, especially parents - may initially lack the necessary capacity and time to develop these skills. ${ }^{403}$ Here, too, structural inequities arise-as when middle-class parents come to dominate traditional channels for participating in schools, like the PTA. ${ }^{404}$

For these and other reasons, the education context has few existing models of authentic structures through which stakeholders can meaningfully engage in governance. Far more common, including among education reformers, are check-the-box exercises in informing constituents of decisions already made. ${ }^{405}$ For example, the legally mandated steps New York City education officials took to engage communities before closing their schools struck most stakeholders as hollow - obligatory gripe sessions after which officials proceeded as they had always intended. ${ }^{406}$ As a recent study of community engagement in a sampling of schools districts nationwide concluded, school "[d]istrict leaders ... embrace the term 'public engagement' [but] most define it as advancing . . . their own agendas, and their experiences with it ... are often negative." 407

Finally, the resources required to revamp external relations through expanded and enriched participation are in especially short supply in school systems simultaneously transitioning to experimentalist internal governance. It is daunting enough to make the changes in organization, operations, and mindset needed to replace bureaucratic and craft cultures with team-based inquiry, measurement, facilitation, and multi-directional information flows. Extending parallel changes to tens or hundreds of thousands of families in myriad neighborhoods significantly increases the

403. See Minow, supra note 277, at 336: Ash, supra note 389.

404. See Debra Monroe, When Elite Parents Dominate Volunteers, Children Lose, N.Y. TiMES (Jan. 19, 2014, 8:00 AM), https://parenting.blogs.nytimes.com/2014/01/19/a-balancedschool-needs-a-balance-of-volunteers.

405. See FARKAS \& Duffett, supra note 32, at 8; NAT'L CTR. FOR Educ. STATISTiCs, Who Influences Decisionmaking About School CuRriculum: What Do Principals SAY? (1995), https://nces.ed.gov/pubs95/95780.pdf (suggesting principals perceive themselves and teachers as having the most decision-making power, with little power in parents).

406. See supra notes 376-84 and accompanying text.

407. FARKAS \& DUFFETT, supra note 32 , at 8. 
trouble the switch to democratic experimentalism entails. ${ }^{408}$

\section{B. Authentic Experimentalist Engagement in Public Education}

Although imposing, the obstacles to a more democratic experimentalism in public education are not insurmountable. At each governance layer, school systems can effectively enable stakeholdersin proportion to their desire, capacity, and time - to put their information, ideas, and criticism to work to improve schools and student results. Recognizing that there is no one model of new politics suited to each constituency, school, or district, this Section assembles an illustrative sampling of structures districts and schools can create to promote authentic, independent, broadly participatory problem-solving.

To succeed, the new politics must be authentic. They must give educators, parents, and others real responsibility and authority to solve problems that directly affect them. And they must provide schools and districts with effective ways to use stakeholders' knowledge about their own, their children's, and their neighbors' conditions and experiences to improve student results. The new politics entails a social contract. Stakeholders, both external (e.g., parents) and internal (e.g., teachers), agree to participate meaningfully in reforms, implement collective decisions and success metrics with fidelity to common goals, and provide honest feedback about how well or poorly strategies and metrics work to resolve unsatisfactory learning conditions and outcomes. In exchange, school officials must give stakeholders meaningful ways to define and solve problems commensurate with their desire and ability to participate; to enhance those abilities; to criticize and trigger changes in plans, implementation, results, measures of success, and objectives; and to learn about changes made or why they weren't made. Adherence to this social contract creates an ethical situation in which a common commitment to solving agreed-upon problems - and to measuring actions and results and being accountable for adjusting actions and objectives based on demonstrated success - neutralizes otherwise confounding differences in interests, values, and beliefs. ${ }^{409}$

The remainder of this Part describes structures districts and schools can create-and that some are already using - to achieve more

408. Consider the New York City system's more than 1 million children speaking over 180 different languages, 850,000 families, 1700 schools, 90,000 instructional staff, and 135,000 employees. Language Access Plan, N.Y.C. DEP'T EDUC., http://schools.nyc.gov/RulesPolicies/ languagepolicy.htm (last visited Jan. 30, 2017); Statistical Summaries, N.Y.C. DeP'T EduC., http://schools.nyc.gov/AboutUs/schools/data/stats/default.htm (last visited Jan. 30, 2017).

409. See supra Section III.A. 
participatory politics. ${ }^{410}$ Throughout, the analysis acknowledges, and suggests how to take the many incremental steps required before many stakeholders can participate meaningfully in and trust the process.

\section{Educators}

As is described above, recent education reforms often call upon principals, teachers, and support staff to use inquiry and other forms of planning, measurement, and adjustment to resolve difficulties students and teachers encounter in the classroom. ${ }^{411}$ Friction remains, ${ }^{412}$ however, particularly as a result of high-stakes teacher evaluation and other managerialist influences that have crept into the reforms, and because districts and schools have not built sufficient time into educators' schedules to enable them to engage in meaningful problem-solving without neglecting other responsibilities. Appropriately allocating time and other resources and giving educators agency to use the new structures to further their own professional development and advancement are crucial to effective engagement, as the examples below demonstrate.

In the award-winning Aldine Independent School District near Houston, Texas, district leaders began reforms by inviting teachers to develop the grade-by-grade standards to which they would teach, as well as the curriculum and the scope and sequence of lessons the district would use to meet the standards. ${ }^{413}$ Although the process took several years, the district recognized 'the importance of teachers' involvement in the curriculum-development process because 'they will be the ones to use it every day." 414 The district asks each school to develop goals for students' mastery of the standards and plans for meeting the goals. ${ }^{415}$ Recognizing that even well-designed curricula and plans will not work for every student, the district authorizes teams of educators to revise both

410. Supplementing this Article's focus on how districts and schools can engage teacher and external stakeholders is a recent report describing how state education departments and districts may "leverage local learning" in schools. Betheny Gross, What Works? Evidence-Based Policymaking Under ESSA, SEA FutURE, Nov. 2016, at 25, 32-33.

411. See supra notes $92,139-40$ and accompanying text.

412. See FARKAS \& DufFetT, supra note 32, at 6 ("School leaders, teachers, and other educators frequently see themselves - and public schooling more generally-as besieged and repeatedly second-guessed. ... Th[is] dynamic colors educators' responses to innovations and calls for reform, and it undermines relationships within and outside the schools that are needed to advance progress."); Allie Bidwell, Most Teachers Are Not Engaged in Their Jobs, Gallup Finds, U.S. News (Apr. 9, 2014, 3:01 AM), http://www.usnews.com/news/articles/2014/04/09/mostteachers-are-not-engaged-in-their-jobs-gallup-finds ("[Teachers] don't believe their opinions count.").

413. ZAVADSKY, supra note 212, at 15, 28.

414. Id. at $29-30$.

415. Id. at 28 . 
as warranted by student needs. ${ }^{416}$ It supports the process by building time into daily schedules for regular collaboration among teachers, ${ }^{417}$ inviting schools to target professional development to problem areas, ${ }^{418}$ and looking for patterns of centrally solvable problems. "When weaknesses are found, ... . initiatives and interventions are selected through a systemic 'root cause analysis.' Stakeholders from all levels of the system are involved in this process and work together by backward mapping through the data to pinpoint deficiencies." 419 To retain and build talent and capacity among its educators, the district uses mentorship programs and hires and promotes teachers and principals from within the district. ${ }^{420}$

In 2009, with the Metro Nashville Public Schools (MNPS) on the brink of takeover by the State of Tennessee, newly appointed schools director Jesse Register developed Principal Leadership Institutes (PLIs) to enable school leaders to learn from one another while creating a common culture of excellence. ${ }^{421}$ By the second year, MNPS principals themselves led most of the PLI groups. ${ }^{422}$ The PLIs formalized training on how to improve teacher practices and retain those that performed well $^{423}$ and emphasized principals' and teachers' effective use of data to identify weaknesses and drive improved instruction. ${ }^{424}$ Reinforcing the latter impulse, the district hired instructional coaches to assist teachers in understanding and using the data. ${ }^{425}$ After principals returned to their schools, they continued to rely on the PLIs for collaborative learning and to develop support networks among peers. ${ }^{426}$ In 2012, the district used the findings of the prior PLIs to develop a five-year strategic plan empowering principals and giving them clearer direction on how to use their new skills to achieve positive student outcomes. ${ }^{427}$ Together with an allied initiative extending collaborative problem-solving to families through engagement in schools with social services organizations, PLIs

416. $I d$. at $28-29$.

417. Id. at 35 .

418. Id. at 36 ("Schools create their own professional development plans based on their student performance and classroom walkthrough data.").

419. Id. at 45 .

420. Id. at 33 .

421. Alethea Frazier Raynor et al., AnNenberg Inst. for Sch. Reform at Brown Univ., Leading by Example: Principal Leadership Institutes as a Driver for Change in Metro Nashville Public SCHOOLs 1-2 (2015), http://www.annenberginstitute.org/sites/default/ files/product/824/files/Nashville_Report_final.pdf.

422. Id. at 3 .

423. Id. at 15 .

424. Id. at 18 .

425. Id. at 19 .

426. Id. at 12-13.

427. Id. at 10 . 
have been linked to rising student enrollment and graduation rates. ${ }^{428}$

Facilitators connecting the central administration with schools and schools with one another can play a key role in the new governance and political processes. An example is the corps of Senior Achievement Facilitators (SAFs) New York City used to introduce educators to an array of novel experimentalist tools. ${ }^{429}$ Former hierarchical supervisors retrained as "heterarchical" facilitators, ${ }^{430}$ SAFs served as an outside "push," encouraging and training educators to use a new data system, diagnostic assessments, and various data reports, and, crucially, as a "sounding board" for reporting and validating school-level criticisms of the tools back to the center. ${ }^{431}$ By promoting the new tools to field staff while demanding needed changes from the center on their behalf, then conveying the changes back to the field and showing that the center was listening, SAFs enforced both sides of the DE social contract. ${ }^{432}$ SAFs also provided educators with an important resource, linking them to research and effective practices and reducing the strain the reforms placed on their time. ${ }^{433}$

These examples include the following characteristics to varying degrees: (1) meaningfully engaging educators in district, school, and classroom decision-making; (2) educating educators, with a focus on data-driven improvement of instruction and learning; and (3) providing the time and support educators need to effectively implement reforms. Acknowledging the importance of educator input while investing educators with the responsibility and support they need to confront and enhance transparent results fosters "internal" accountability and motivates, empowers, and enables educators to think critically about how

428. MNPS, High Sch. Student Performance Trends 4-5 (2015), http://www.ncacinc.com/sites/default/files/media/documents/MNPS_High_School_Performance 2015.pdf; MNPS, The Journey to CREATing EXCELlenCe For Every STUdent 1, 6, 10, 12 (2015), https://mnpschildrenfirst.files.wordpress.com/2015/04/metro-schools-journey-web.pdf; RAYNOR, ET AL., ANNENBERg INST. FOR SCH. REFORM, MNPS ACHIEVES YeAR 3 EVALUATION: PRELIMINARY FINDINGS 1 (2012), http://www.annenberginstitute.org/sites/default/files/Nashville Evaluation_Year3.pdf.

429. Joan E. Talbert, Collaborative Inquiry to Expand Student Success in New York City Schools, in EdUCATION REFORM IN NEW YoRK City, supra note 90, at 131, 135.

430. See supra note 92 and accompanying text.

431. Talbert, supra note 429 , at 149 ("The process was so frustrating at times that I think if there wasn't an outsider pushing you, we just would have said: 'No. It's not working.' . . . Just having an outsider to keep pushing you and still be there was critical." (quoting a teacher)); Marian A. Robinson et al., Consortium for Pol'y Research in EduC., A Formative Study of the Implementation of the Inquiry Team Process in New York City Public Schools: 2007-08 FindINGS 58 (2008), http://www.cpre.org/sites/default/files/researchreport/1030 cfiresearchreport2008.pdf.

432. See supra note 92 and accompanying text.

433. See Talbert, supra note 429 , at $135,137$. 
best to improve outcomes. ${ }^{434}$ Learning to conduct and facilitate these inquiries, however, requires educators to step out of their traditional role as educators of children and into roles as educators of one another and themselves.

\section{Parents}

As with educators, effective engagement with parents and their communities requires that they have (1) an ongoing role in decisionmaking; (2) the information, opportunities consistent with other demands on their time, problem-solving structures, and capacity or training needed to do so; and (3) an assurance that their input is valued and will influence the outcome or elicit an explanation of why it did not. ${ }^{435}$ Meeting these goals is more difficult with parents and community members than with educators, however, because the former are not trained, selected, and paid to be present to problem-solve ${ }^{436}$ and are not obliged - and may not be disposed - to address considerations reaching beyond their own children. ${ }^{437}$

Incorporating parents thus requires officials-or, better yet, Community Based Organizations (CBOs) playing a mediating role and limiting opportunities for co-optation ${ }^{438}$ - to meet parents where they are. Officials and CBOs must provide multiple entry points geared initially to parents' concerns about their own children, schools, and neighborhoods; ways of participating consistent with a range of capacity levels and time commitments; disaggregation of complex problems into smaller projects and steps; and "quick wins" that expand capacity, trust, confidence, and disposition to devote available time to incrementally broadening categories of issues and considerations. ${ }^{439}$ Manifestly, these steps require massive, if gradual, shifts in officials', educators', CBOs', and stakeholders' expectations, routines, and mindsets. These changes will

434. See Grantmakers for Educ., A Toolkit for Teacher Engagement 7, https://www.edfunders.org/sites/default/files/GFEToolkit_FNL.pdf; supra note 92 (discussing internal accountability).

435. See, e.g., Educ. Trust-West, Building a More Equitable and Participatory School System in California: The Local Control Funding Formula's First Year 26 (2014), http://west.edtrust.org/wp-content/uploads/sites/3/2015/02/ETW-Building-a-MoreEquitable-and-Participatory-School-System-in-California-Report_0.pdf ("Districts that are embracing the idea of participatory planning are engaging stakeholders throughout the year and are building the capacity of [team] members to serve as leaders, community ambassadors, and true partners.").

436. See Annenberg Inst. For Sch. Reform, Family Engagement and Education 5-12 (2014) (discussing parent-engagement challenges in Pittsburgh Public Schools).

437. See supra Section V.A.

438. See infra Subsection V.B.3.

439. See, e.g., ANSELL, supra note 22, at 86; infra Subsection V.B.3. 
not occur automatically. As illustrated by the drug-court and Traxtonpolicing examples, they require thoughtful structures, protocols, and facilitation that widen participation and perspectives and are easily customized to context and adjusted in response to feedback and results. ${ }^{440}$

Without asking parents to transcend immediate concerns, schools can create opportunities for them to collaborate with educators to accelerate the learning of their own and other children, jointly track progress, and adjust actions in accordance with transparently shared information. Illustrating what is possible are Academic Parent Teacher Teams (APTT), first developed in 2010 to replace traditional parent-teacher conferences with periodic meetings at which teachers coach all parents in their classroom on how to interpret their child's performance by comparison to "overall classroom performance, school benchmarks, and state standards"; work with parents to "set goals for their students, individually and as a class"; and develop "strategies and tools to support learning at home." ${ }^{441}$ The teacher and parents of each child agree on a sixty-day improvement goal for the child and meet one on one after sixty days to review progress, identify improvement areas and strategies, and set new goals. ${ }^{442}$ As a group, parents identify strategies that have been working at home, both to inform classroom instruction and spread knowledge to one another. ${ }^{443}$ Steps are taken to assure broad parent accessibility through translation of materials, transportation, childcare, and distance participation via FaceTime or Skype. ${ }^{444}$

APTTs require only modest commitments and slowly build parents' capacity to participate and partner with teachers and other parents in improving the education of their own and other children. They also sow seeds for greater parental engagement, including parent participation on inquiry teams, which use close analysis of children struggling to learn or educators struggling to teach particular skills to signal a need for and identify targeted classroom-, school-, and district-wide changes in learning conditions and instructional practice. ${ }^{445}$

440. See supra Subsections III.C.2, III.C.4, \& IV.B.1.

441. U.S. Dep'T of Educ., An InNovative Model for Parent-Teacher Partnerships (2010), https://www.ed.gov/sites/default/files/School\%20Turnaround\%20Newsletter\%20-\%20 December\%202010.pdf; see Sarah D. Sparks, Parent-Teacher Conferences Get a Makeover, ED. WeEK (Sept. 29, 2015), http://www.edweek.org/ew/articles/2015/09/30/parent-teacherconferences-get-a-makeover.html.

442. Empowering Families to Improve Student Learning, WESTED (Dec. 29, 2015), https://www.wested.org/rd_alert_online/empowering-families-to-improve-student-learning.

443. See APTT, Stanton APTT Workshop, YouTube (July 16, 2012), https://www.youtube.com/watch?v=1YNsWrFiYfY.

444. See, e.g., EdUC. TRUST-WeSt, supra note 435, at 10.

445. See Data for Decisions: Frequently Asked Questions, WeSTED, http://datafordecisions. wested.org/data-use-basics/frequently-asked-questions (last visited May 20, 2017) (advocating 
Engagement strategies like APTT and collaborative inquiry that gradually move parents' focus beyond their own child's instruction infinitely expand the range of issues within reach of parent problemsolving. For example, parent working groups might assemble to address small day-to-day problems at schools; create engagement tools and strategies for district-wide use; offer advice and misgivings at each stage of the goal-identification, design, piloting, and implementation of all major district-wide initiatives; or develop plans for saving and models for replacing failing schools. Of course, the further afield these initiatives go, the greater the accessibility and capacity hurdles they face. Examples of initiatives of just these sorts reveal, however, that the hurdles are not insurmountable.

Efforts in 1995-2003 by parents and community organizers at the McClure School in Philadelphia's low-income, mostly minority Hunting Park neighborhood exemplify what school-level parent problem-solving can accomplish. ${ }^{446}$ McClure parents initially joined with community organizers and school personnel to improve school security. ${ }^{447}$ Becoming more adept at problem-solving, parents turned their attention to literacy, winning the school's agreement to assess students to determine their reading levels. ${ }^{448}$ When scores well below grade level called into question the high grades students were receiving in class, parents pressed for an explanation. ${ }^{449}$ The principal reacted by withdrawing permission for the group to meet at the school. ${ }^{450}$ Complaints to the district led to the principal's ouster and a chance to help select a new school leader committed to focusing intensely on reading. ${ }^{451}$ In subsequent years, the parents rebuilt trust with teachers by collaborating to refurbish the school's library and hire a librarian-again with strong parent involvement - eventually convincing over 75 percent of the school staff to invoke a waiver provision in the district's collective-bargaining

parent involvement in "data-driven decision making processes" to enhance parents' capacity to help improve schools); supra notes 92, 139-40 and accompanying text (discussing inquiry teams). Although "[n]arrow interpretations of the [Family Educational Rights and Privacy Act, 20 U.S.C. $\S 1232 \mathrm{~g}]$ have led many schools to restrict ... information sharing" with parents, the APTT model of sharing student-level data only with each child's parents, data anonymization, and parental consent can overcome these obstacles. TUCKER, supra note 138, at 10, 12; see U.S. DEPT. OF Educ., Privacy tech. Assistance Ctr., Data De-Identification: An Overview of Basic TERMS (2013), http://ptac.ed.gov/sites/default/files/data_deidentification_terms.pdf(listing ways to share school data and protect privacy).

446. Gordon Whitman, Making Accountability Work, 28 N.Y.U. Rev. L. \& Soc. CHANGE 361,361 (2003).

447. $I d$.

448. Id.

449. Id.

450. Id.

451. Id. 
agreement allowing a joint committee of administrators, teachers, and parents to select all new teachers. ${ }^{452}$ Following these changes, the percentage of students reading at grade level increased from 29 percent to 53 percent. ${ }^{453}$

A district-level example arose from a miscalculation the New York City Department of Education (DOE) made in designing its first set of student, parent, and teacher surveys for rating schools. ${ }^{454}$ The 2007 inaugural version of the survey excluded fifty-plus "District 75 " schools for severely disabled students, because most questions did not apply. ${ }^{455}$ Facing parents upset by the snub, the DOE invited them, with central support, to design the District 75 survey themselves. Without committing to adopting their draft wholesale, DOE promised to explain any changes it made to the parents' proposal. To build capacity and facilitate without steering or micro-managing, the DOE hosted the meetings, supplied data and exemplars used in developing the surveys for other schools, and, when asked but not otherwise, advised on draft language. In the end, the DOE adopted well over 90 percent of the parents' draft. The resulting survey is used to this day. ${ }^{456}$

Kaya Henderson, Michelle Rhee's successor as D.C. schools chancellor, turned to experimentalist community problem-solving to address an even more vexing issue: school closures. Instead of listing schools the district planned to shutter and engaging in pro forma exercises to enable opponents to make objections officials had already predicted and rejected - the typical procedure-Henderson announced only "a proposal, a pliable draft" to close schools, then invited affected teachers, parents, students, and community members to develop concrete plans for alleviating the poor performance and declining enrollment that landed

452. Id. at 361-62.

453. Id. at 362. McClure has not entirely sustained its momentum. See COMMONwEALTH of Pa., 2015-2016 School Progress Report: Alexander K. McClure School, https://webapps1.philasd.org/downloads/school_profile/spr_reports/SY1516/7380_ES_SPR_SY 1516.pdf (reporting that only 39 percent of K-2 students were reading at grade level in the 20152016 school year).

454. See N.Y.C. DeP'T of EduC. supra note 81 (citing survey results).

455. Erin Einhorn, Disabled in Survey Snub, N.Y. Daily News (May 15, 2007, 4:00 AM), http://www.nydailynews.com/news/disabled-survey-snub-article-1.251904. The lead author of this Article managed this project in his capacity as head of the New York City Department of Education's Division of Accountability and Achievement Resources. The discussion here reflects his observations of the process.

456. See NYC School Survey District 75, N.Y.C. DEP'T EDUC., http://text.nycenet.edu/ Accountability/tools/survey/district75.htm (last visited May 20, 2017) ("[T]he [District 75 survey] specifically addresses the unique experience in District 75 schools for all constituents."); N.Y.C. Dep't of Educ., Citywide Question-By-Question Survey Results For District 75 SCHOOLS (2013), http://schools.nyc.gov/NR/rdonlyres/BC50BC6B-A873-4951-BF90-7B266D 0A7E12/0/2013SchoolSurveyCitywideResultsforDistrict75Schools.pdf. 
their school on the list. ${ }^{457}$ Making clear that plans would be evaluated on the strength of their turnaround mechanisms, not the emotion with which they were presented, Henderson urged communities to put skin in the game, describing meaningful resources and actions they would contribute alongside ones they needed the district to offer. ${ }^{458}$ Based on proposals submitted, Henderson spared five of the twenty schools on the closure list in the first run of the new process. ${ }^{459}$ The fact, however, that most of the successful proposals came from middle-class, not poorer, communities suggests that something more than the opportunity to engage is needed to allow all communities to participate meaningfully.

To be sure, even effective outreach, training, and facilitation will not entirely immunize collaborative problem-solving from all disparities in power and access. But mitigating the egregious disparities that currently exist - not magnifying them, as limited stakeholder engagement typically does today ${ }^{460}$ - is a vast improvement, which commitment and perseverance by school leaders can accelerate. ${ }^{461}$ So can support from CBOs, as the next Section elaborates.

\section{Supportive Organizations}

To help schools and districts build the capacity, provide the resources, and safeguard the stakeholder autonomy that effective DE requires, CBO facilitation and mediation may be essential. Having already built trust and lines of communication with families and other stakeholders, assessed their needs and capacities, and learned how to help them access services and hold providers accountable, CBOs are often best placed to engage public education stakeholders in appropriate types and levels of engagement. Additionally, CBOs can provide the skilled facilitation needed to coax participants into ethical situations in which they work together to identify and address the most pressing problems facing the entire community, assist stakeholders in interpreting and acting on data acquired through the experimentalist process, and serve as a repository of

457. Emma Brown, D.C. Parents Develop Alternatives to Chancellor's School-Closure Plan, Wash. Post (Jan. 1, 2013), http://www.washingtonpost.com/local/education/dc-parentsdevelop-alternatives-to-chancellors-school-closure-plan/2013/01/01/3e58f9e4-4b92-11e2-b709667035ff9029_story.html.

458. Id ; see, e.g., D.C. PUB. SCH., GARRISOn ElemENTARY - A COMMUnity COMMITMENT: Five-Year Strategic Plan Proposal (Dec. 18, 2012), http://www.scribd.com/doc/117605412/ Garrison-Elementary-Chancellor-Presentation-Final.

459. Brown, supra note 457.

460. See supra Section I.B \& Subsection IV.B.2.

461. See Annenberg Inst. for Sch. Reform, Capturing the Ripple EfFect: Developing a Theory of Change for Evaluating Parent Leadership Initiatives 1,8 (2016), http://www.annenberginstitute.org/sites/default/files/product/893/files/capturingtherippleeffectre portweb.pdf . 
past experience to inform new cases even as other participants move or age out of the relevant community. CBOs also may be better equipped than school officials for the difficult task of intimately guiding stakeholders while letting them make key decisions and do real work, though they, too, may be become excessively hands-on, coopting the reforms and disenfranchising stakeholders.

Excel Bridgeport, a school-reform CBO in Bridgeport, Connecticut, is an example of an organization that builds families' capacity to use collaborative problem-solving to improve schools. ${ }^{462}$ Illustrating the organization's approach is its sponsorship of a "problem-solving parent group" (PSG) that undertook to rewrite the Bridgeport School District's previously pro forma Parent Engagement Policy, then convinced the school board to adopt its redraft. ${ }^{463}$ The group's decision to rewrite the policy, and the process it followed in doing so, were themselves experimentalist and democratic. When Excel Bridgeport teamed up with Columbia University's Center for Public Research and Leadership (CPRL) to support the parent group, they assumed the group would address a contained issue such as unkempt conditions at a single school. ${ }^{464}$ From the outset, however, Excel Bridgeport and CPRL made parent control the guiding principle and supported the PSG with protocols that let it decide the problem to tackle and guided it beyond complaining about the problem to working with the community and officials to solve it. ${ }^{465}$

The problem-solving tools CPRL's team developed on demand by the PSG tell the story of the group's work: Group Norms; Meeting Structure Guidelines; Decision-Making Options (the team chose consensus over majority rule); Sentence Starters for Group Discussion and Feedback; Survey Distribution Options (for collecting community views on priority problems); Problem-Selection Rubric; The 5-Whys: Finding the Cause of the Problem; Brainstorming Solutions; Best Practices Research; Solution Selection Assignment; Strategy Evaluation Worksheet; Performance

462. About, EXCEL BRIDGEPORT, https://excelbridgeport.wordpress.com/about (last visited Feb. 11, 2017); Parent-Driven Reform: Bridgeport Parents Make History!, EXCEL BRIDGEPORT (Aug. 10, 2012), https://excelbridgeport.wordpress.com/2012/08/10/parent-driven-schoolreform-bridgeport-parents-make-history ("The 'problem solving' approach to community engagement empowers parents to tackle the challenges in their schools head-on and work toward productive solutions. Through this model, parents (as active participants in school improvement) have the potential to transform an entire school district.").

463. Michele Molnar, Parents Take Lead in District's Engagement Policy, Educ. WK. (Aug. 14, 2012, 2:41 PM), http://blogs.edweek.org/edweek/parentsandthepublic/2012/08/the bridgeport_conn_board_of.html.

464. Telephone Interview with Maria Zambrano, Executive Director, Excel Bridgeport (Nov. 12, 2013). The lead author of this Article is CPRL's founding director.

465. Id. 
Indicator Worksheet (for developing success measures the group thereafter tracked); PSG Reflective Guide (for analyzing success to date and how to improve); After Action Review; and Presentation Tips. These tools (since collected in a manual for subsequent PSGs) ${ }^{466} \mathrm{kept}$ the focus on attainable goals and encouraged team members to assess actions on an agreed-upon objective basis - whether they demonstrably helped solve the problem at hand - thus defusing ideological and other differences. ${ }^{467}$ As in the Traxton community-policing example, ${ }^{468}$ there were initially capacity imbalances; only some parents had participated in civic action before. Unlike in Traxton's early stages, however, PSG participants from the outset used structures to collect and prioritize district-wide problems, assuring that less experienced parents were not drowned out. ${ }^{469}$ The team member the others chose to facilitate was essential, doing a "remarkable job" of bringing everyone into the conversation. ${ }^{470}$

Not everything went smoothly. ${ }^{471}$ Established parent groups known as Parent Action Councils (PACs) worried that any success the PSG had in changing the Parent Engagement Policy might reflect poorly on them, and those PACs, together with school board members and central officials loath to offend the PACs, initially resisted the PSG process. ${ }^{472}$ Union representatives resisted some engagement proposals as adding work for teachers without compensation. ${ }^{473}$ Resolving to join not fight, the PSG added PAC members to the team and gave more than thirty presentations to individual PACs. ${ }^{474}$ Following eight months of

466. Columbia Univ. Ctr. For Pub. Research \& Leadership, Parent Problem-Solving Groups: A New APPROACH TO PARENT ENGAGEMENT AND APPENDIX (2013) (on file with author).

467. Id. at app. I; see ANNENBERG INST. FOR SCH. REFORM, supra note 461, at 3.

468. See supra Subsection III.C.4.

469. Interview with Maria Zambrano, supra note 464; see supra Subsection III.C.4 (discussing Traxton); see also Christine CAmpbell, Ctr. on Reinventing Pub. Educ., Roots of Engagement in Baton Rouge: How Community Is Shaping the Growth of New School OpTIONS 7 (2016), http://www.crpe.org/sites/default/files/crpe-roots-of-engagement-4-2016.pdf (" $[\mathrm{T}] \mathrm{o}$ engage our community to become active in the well-being of students, change must come from within ... [, and] informed community demand is necessary to build long-term change in urban education." (emphasis added)).

470. Telephone Interview with Ayeola Kinlaw, Engagement Manager, Ctr. for Pub. Research \& Leadership (Oct. 18, 2013).

471. Molnar, supra note 463 (reporting one member's surprise "at how much the parents in the problem-solving group needed to advocate for the proposed parent engagement policysometimes experiencing negativity from groups even when they had not read it").

472. Interview with Ayeola Kinlaw, supra note 470.

473. Id.

474. See Bridgeport Parents Are Critical Partners in School Improvement, CT PosT (June 7, 2012, 11:02 AM), http://www.ctpost.com/news/article/Bridgeport-parents-are-criticalpartners-in-3616550.php (describing "collaboration" between Excel Bridgeport and PACs); Molnar, supra note 463. 
intensifying work, the PSG secured the school board's unanimous adoption of a policy calling for a more welcoming school environment; better parent access to schools, teachers, and administrators; clearer expectations; increased communication; and resources to build parents' skills and knowledge to better help their children. ${ }^{475}$

There are other ways CBOs can facilitate experimentalist politics by leveraging the expertise of disparate actors with a stake in change. Efforts to create better schools provide two examples. In the decade ending in 2013, New York City closed numerous large high schools with shockingly low graduation rates, replacing them with smaller schools that eventually graduated many more of their students. ${ }^{476}$ To create new schools, city officials developed a rigorous planning and approval process and encouraged CBOs with experience improving schools to develop new-school proposals meeting requirements for "strong and capable school leadership, high-quality teaching across disciplines, accountability for all students, an academically strong curriculum, ... parent and community engagement, and student voice." 477 CBOs collaborated with union representatives, community groups, and service providers to integrate "high-quality curricula, and instruction and community resources into an extended school day."478 The intense backlash the district later encountered when it expanded school closures, including elementary and middle schools, and relied more heavily on charter schools unengaged in local communities suggests the importance of CBO participation in school closures and

475. Bridgeport Bd. of Educ., Policy Statement: Parent \& Family Engagement in the BRIDGEPORT PUBLIC SCHOOLS (2012), http://bridgeport.ct.schoolwebpages.com/education/ components/scrapbook/default.php?sectiondetailid=67568\&; see Molnar, supra note 463 . When last interviewed, Excel Bridgeport's executive director was working to assemble more PSGs to work with individual schools but noted challenges: Participation is labor intensive, disfavoring single-parent families. Without strong facilitation, parental action tends to move away from problem-solving toward traditional interest-group advocacy. See, e.g., Amy J. Cohen, Negotiation, Meet New Governance: Interests, Skills, and Selves, 33 Law \& Soc. InquiRY 503, 547 (2008) ("[D]iscursive practices such as communication, problem solving, and collaboration [may be] recast into skills [that] become conditions for securing interests, entitlements, and benefits."). The work required of CBOs to prepare parents for the work needed to engage in local problem-solving and scale it to the district level is also demanding. See Interview with Ayeola Kinlaw, supra note 470; Interview with Maria Zambrano, supra note 464; see also Lambeck \& Lockhart, supra note 385; Weiss, supra note 385.

476. See UNTERMAN, supra note 146, at 3-4.

477. Michele Cahill \& Robert L. Hughes, Small Schools, Big Difference, Educ. WK. (Sept. 27, 2010), http://www.edweek.org/ew/articles/2010/09/29/05cahill.h30.html.

478. Id. 
creation as a way to enhance, not diminish, parent engagement and social capital. ${ }^{479}$

Tennessee's Achievement School District (ASD) takes over failing Tennessee schools and restructures them, restarts them as charter schools, or closes them outright. ${ }^{480}$ To avoid a "swoop-down-and-take-over" model or fronting for charter school operators with no "footprint" in Tennessee, the ASD created an "Achievement Advisory Council" (AAC) for Memphis - the location of most of the state's failing schools. ${ }^{481}$ Made up of volunteers from across Memphis who act as a community "sounding board," the ACC collects information from an array of "parents, students, community members, and education leaders" on community-specific Neighborhood Advisory Councils that "assess the strength and fit of school operators interested in transforming low performing schools in their communities." ${ }^{482} \mathrm{AAC}$ recommendations as to which intervention option to adopt and which schools to match with those being replaced count for 40 percent of ASD decisions. ${ }^{483}$ Although community leaders have sometimes described these engagement efforts as "flash mobs," on the whole they appear to have counteracted the sense that something is "being done" to, not with and by, communities. ${ }^{484}$

\section{Traditional Interest Groups}

Suppose education reformers manage to engage stakeholders in ethical situations favoring the demonstrable solution of problems over pursuit of predefined interests, outcomes over inputs, and iterative learning from implementation over negotiated final plans. And suppose these structures surface and effectively serve a wider array of more reflective values and interests than the few and fixed ones around which interest groups typically mobilize their constituencies. The question remains whether school officials and CBOs can implement the new politics if, as past experience forecasts, powerful interest groups

479. See id. ("Partnerships stimulated and offered opportunities for increasing social capital in communities-the talent, caring relationships, opportunities for student involvement, and use of expanded learning environments too often marginal or established outside the school structure.").

480. Nelson Smith, Thomas B. Fordham Inst., Redefining the School District in TENNESSEE 2-3, 7 (2013), http://edex.s3-us-west-2.amazonaws.com/publication/pdfs/20130423Redefining-the-School-District-in-Tennessee-FINAL_7.pdf.

481. Id. at $10-11,18$.

482. Id. at 10; Neighborhood Advisory Council, Achievement Sch. Dist., http://achievementschooldistrict.org/nac/ (last visited Mar. 20, 2017).

483. SмiтH, supra note 480 , at 10.

484. Id. at 20, 24; see Jaclyn Zubrzycki, Tennessee's Achievement School District Ranks High on "Conditions for Success," CHALKBEAT (Nov. 26, 2013), https://www.chalkbeat.org/ posts/tn/2013/11/26/tennessees-achievement-school-district-ranks-high-on-conditions-forsuccess (calling ASD a "national exemplar" in fostering public engagement). 
strenuously oppose the reforms as antithetical to their constituents' immediate needs and their own long-term survival.

Interest groups indeed might fear a loss of relevance if forced to compete for their members' time and resources with highly participatory and deliberative engagement opportunities that acknowledge a fuller range of stakeholders' interests and values and generate more positive and productive relationships with districts, schools, and other stakeholders than do interest groups' typically zero-sum approaches. Faced with this prospect, interest groups may well either transform or resist - possibilities this Article briefly addresses in turn below.

By adopting experimentalist strategies or even evolving into experimentalist organizations, interest groups could better serve their constituents' long-term interest in vibrant and successful public schools, solidify a central place for themselves in the school improvement process, and meaningfully enhance their members' autonomy, professionalism, and efficacy in their chosen careers. To do so, these organizations could leverage and enhance their members' trust and buy-in, contextualized knowledge about crucial problems and solutions, and stake in school improvement. Most importantly, unions and other established groups could use their substantial resources and expertise to develop their members' problem-solving skills, which are no more difficult to instill than the advocacy, organizing, and negotiation skills on which these groups have traditionally relied. Additionally, given their systemic reach, these organizations could help districts and states coordinate individual teachers' and parents' disposition and capacity to fix local problems that particularly bother them via responsibility and knowledge-sharing structures that identify, reward, and spread learning that is useful beyond its initial context. More than school officials and even CBOs, that is, these organizations have the capacity to create ethical situations in which their members hear and learn from each other-and ultimately from unaffiliated stakeholders - to set aside or reprioritize interests they share only with each other in favor of the broader, if contextualized, interests of particular sets of children and communities as well as the educators who serve them.

Educators 4 Excellence (E4E) is an example of interest-group transformation of just this sort. Unlike traditional unions, which pursue policies serving only the small number of assumedly fixed, typically economic, interests that virtually all members have in common, E4E gives "teachers who want to change the top-down approach to policymaking" an opportunity to develop and implement policy and participate in decision-making, beginning with the problems they encounter in their 
everyday interactions with students. ${ }^{485}$ Its primary goals are to elevate the quality and prestige of the teaching profession and to increase student achievement, particularly for students affected by the opportunity gap. ${ }^{486}$ Working in part as affinity groups within existing teachers' unions, E4E's chapters leverage their members' influence and resources in support of policies that prioritize teacher autonomy, flexibility, and efficacy and differentiate among teachers and the contexts in which they serve over wages, conditions, and seniority structures that aim to benefit all educators uniformly. ${ }^{487}$ Examples include flexible teacher evaluations prioritizing observation of low-performing teachers and mentoring of less by more effective educators; ${ }^{488}$ increasing diversity in the professional pipeline through targeted recruitment, induction, and retention; ${ }^{489}$ attracting teachers to high-needs schools through "School Transformation Packages" offering greater-than-usual pay, support, and autonomy; ${ }^{490}$ and basing layoff decisions on preserving the most effective teachers rather than those with the most seniority. ${ }^{491}$ E4E chapters also support reforms tailored to the needs of particular teachers, students, and contexts, such as effective Common Core implementation among English language learners and students with disabilities ${ }^{492}$ and elimination of racial disparities in school discipline. ${ }^{493}$ These positions include specific

485. See Educators 4 Excellence, Teachers Leading Change: 2014-2015 Annual REPORT 3 (2015), https://www.scribd.com/doc/306671692/Teachers-Leading-Change-2014-15Annual-Report; Evan Stone \& Sydney Morris, How We Started, EduCATORs 4 Excellence, http://www.educators4excellence.org/about-us/how-we-started (last visited Mar. 20, 2017).

486. Telephone Interview with Evan Stone, Co-Founder and Co-Executive Officer, E4E (Dec. 6, 2016).

487. Id.

488. Educators 4 Excellence Chi., The Evolution of Evaluation: A Way Forward FOR TEACHERS, BY TEACHERS 15, 18 (2016), http://educators4excellence.s3.amazonaws.com/ 8/29/2/3104/E4E_CHI_EvolutionEvaluation_WEB.pdf.

489. Educators 4 Excellence MinN., Closing Gaps: Diversifying Minnesota's TEACHER WORKFORCE 9 (2015), http://educators4excellence.s3.amazonaws.com/8/e6/2/2606/ E4E2015_MNClosingGaps_Web.pdf.

490. EduCATORS 4 ExCELlenCe L.A., Building the Future: AtTRacting AND Retaining Great Teachers in Hard-TO-StafF Schools 6 (2013), https://www.scribd.com/document/ 147628923/Building-for-the-Future-Attracting-and-Retaining-Great-Teachers-in-Hard-to-StaffSchools.

491. Educators 4 Excellence, Keeping Our Best Teachers: An Alternative to SENIORITY-BASED LAYOFFS 2-4 (2016), http://educators4excellence.s3.amazonaws.com/8/1c/b/ 1363/E4E_LIFO_White_Paper.pdf.

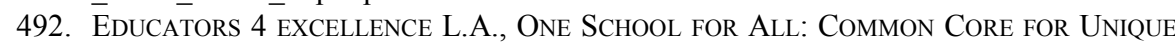
StUdent Populations 1-2 (2016), http://educators4excellence.s3.amazonaws.com/8/63/d/ 3084/E4E2016_LACommonCore_WEB.pdf.

493. Educators 4 excellence Minn., Ending Racial Discipline Disparities: An Educator's Guide to SCHOOl-BASEd Change 2 (2016), https://www.scribd.com/doc/ 
recommendations at the state, district, and traditional union level and rely on a data-driven approach that uses the implementation of reforms to generate feedback about how to improve them. ${ }^{494}$

To develop these positions, E4E chapters engage in participatory and deliberative problem-solving. Believing that the processes leading to the development of many influential union policies do not sufficiently integrate the voices of teachers, E4E's founders created structures to engage educators more directly. ${ }^{495}$ At schools, members form into teams of fifteen to twenty teachers to draft white papers and recommendations on issues surfaced by the group's wider membership. Facilitators with policy backgrounds help members synthesize research and identify key findings. Teams conduct surveys and focus groups, then iteratively review and revise their findings and drafts with participating colleagues to assure that teacher experiences are accurately captured. ${ }^{496}$ Rather than limiting proposals to ones reflecting interests all members have in common, E4E has found that, as long as educators understand its iterative process, have a meaningful chance to engage at every stage, and understand why the ultimate proposal deviates from their preferred outcome, they will support proposals with which they do not fully agree. $^{497}$

Not surprisingly, union traditionalists view E4E with intense suspicion-criticizing its teacher-differentiating policies and ties to reform-oriented education officials and philanthropies as "managementlinked interference with union affairs" and urging union members that "[i]f you see them in your school, please let us know." ${ }^{498}$ E4E's model, that is, might only heighten resistance to new politics and governance.

Thus far, however, E4E has leveraged its position inside unions, support for collective bargaining, and rising numbers of chapters and members into a potent, if not yet majority, force for change. ${ }^{499}$ With E4E's encouragement, its members run for leadership positions in local unions and currently hold over 300 such positions around the nation. These and other members vocally support E4E proposals with which unions strongly disagree-including teacher evaluation, limits on student discipline, and layoffs based on teacher effectiveness rather than

309969205/Ending-Racial-Discipline-Disparities-An-Educator-s-Guide-to-School-based-

Change.

494. Interview with Evan Stone, supra note 486.

495. Id.

496. Id.

497. Id.

498. BTU Staff, Getting to the Bottom of Educators for Excellence, Bos. TEACHERS UNION (Dec. 4, 2015), https://btu.org/bottom-educators-excellence.

499. Interview with Evan Stone, supra note 486. 
seniority. ${ }^{500}$ Citing unions' ultimate goal of enhanced teacher quality and prestige and their fiduciary duty to advance policies most members support, E4E's leadership believes that by enabling teachers to engage meaningfully on policy affecting their day-to-day experience, the group can pressure unions from within to alter existing special-interest politics. ${ }^{501}$ Taken to its limit, this logic could lead to interest-group structures that strengthen, rather than obstruct, experimentalist policies and politics. As have environmental advocacy groups in the environmental protection context, the Department of Justice for drug courts, universities in Finnish special education, and CBOs in community policing and education, unions and other education-sector interest groups could become crucial partners in collaborative problem-solvingparticularly by representing, capacitating, and rationing the time commitments of their members.

As the examples in Section III.C and this Section reveal, districts, schools, CBOs, and evolving interest groups can enable authentic problem-solving by a broad range of stakeholders operating at many commitment and capacity levels. Under a more fully democratic model, that is, there is no reason why teachers, parents, students, communities, and groups representing them cannot come together to identify and make progress solving most problems public schools face.

To be sure, this Article cannot predict the stance traditional interest groups would take toward the reforms discussed in this Article if given the opportunity previously denied them to engage fully and consequentially - albeit through experimentalist, not pluralist, politics. And if the best organized of those groups with the most at staketeachers' unions, primarily - continue resisting rather than participating, this Article cannot predict the fate of the reforms. This Article anticipates, however, that by providing a meaningful role for more stakeholders, nurturing a fuller range of those stakeholders' interests and values, and giving them more power to solve problems and enhance their personal and professional efficacy and their children's and students' outcomes, the new structures will place existing interest groups under serious pressure to evolve in order to survive. This may be especially true in an era in which public teachers' unions and public education generally face new pressures to improve services to key clients or be forcibly and radically altered. ${ }^{502}$ Under these circumstances, the promising improvements the

500. $I d$.

501. Id.

502. See, e.g., Harold Meyerson, Donald Trump Can Kill the American Union, Wash. Post (Nov. 23, 2016), https://www.washingtonpost.com/posteverything/wp/2016/11/23/donaldtrump-could-kill-the-american-union; Valerie Strauss, Will Donald Trump Destroy U.S. Public 
reforms have shown to be possible may be the last best hope of the public school system as we know it today. ${ }^{503}$

\section{CONCLUSION}

Having shed bureaucracy, the new public education reforms' experimentalist governance is their sinew of steel, lifting student learning outcomes and stabilizing a public education system at risk of collapse. ${ }^{504}$ But the reforms' banishment of special-interest politics while offering no replacement is the reforms' kryptonite, alienating the populations that most need the reforms and strengthening the special interests that in their current form are the reforms' - and public education's - nemesis. ${ }^{505} \mathrm{In}$ this as in other contexts, novel experimentalist forms of governance cannot succeed without new, pragmatically participatory and deliberative, politics. ${ }^{506}$

In the new education politics this Article envisions, parents and other stakeholders participate in the reforms at every level of the system, using an array of entry points, collaborative problem-solving frameworks, and supports from districts, schools, CBOs, and reoriented interest groups. As stakeholders work with others to address problems closest to home, they gain facility and confidence as evidence-driven experimentalists, readying themselves to take on bigger problems. As they integrate governance and politics - watching diverse teammates coalesce around problems to solve, causal hypotheses, provisional solutions, and adjustments in response to results - and as they gain transparency into how government works and see their efforts gradually improve outcomes, stakeholders and school systems for the first time achieve legitimate, accountable, and workable alternatives to bureaucracy and specialinterest politics.

Education?, WASH. POST (Nov. 14, 2016), https://www.washingtonpost.com/news/answersheet/wp/2016/11/14/will-donald-trump-destroy-u-s-public-education.

503. See supra Section I.C.

504. See supra Sections I.A, III.A.1, \& IV.A.

505. See supra Introduction, Sections I.B, IV.B.

506. See supra Sections III.A.2, III.C. 
